Copyright

by

Matthew Stephen Ege

2013 
The Dissertation Committee for Matthew Stephen Ege Certifies that this is the approved version of the following dissertation:

Does Internal Audit Function Quality Deter Management Misconduct?

\section{Committee:}

Urton Anderson, Co-Supervisor

John Robinson, Co-Supervisor

Dain Donelson

John McInnis

Thomas Sager 
Does Internal Audit Function Quality Deter Management Misconduct?

by

Matthew Stephen Ege, B.B.A., M.S.

\author{
Dissertation \\ Presented to the Faculty of the Graduate School of \\ The University of Texas at Austin \\ in Partial Fulfillment \\ of the Requirements \\ for the Degree of \\ Doctor of Philosophy
}

The University of Texas at Austin

August 2013 


\section{Dedication}

To Kimberly. You are truly beautiful.

Ephesians 3: 20, 21 


\section{Acknowledgements}

I am grateful to my committee members for their sacrificial giving of time, consistent encouragement, and willingness to share insights. I am particularly grateful to Urton Anderson, who encouraged me to pursue an internal audit project and assisted immensely in obtaining the necessary data. The academic environment is necessarily critical. Because of this, one's character is readily revealed during the exchange of ideas and interactions with colleagues and students. The character of each of my committee members shone through during the past couple of years. They are each able to critically move collective knowledge forward, while genuinely caring for others. I benefited directly from the character of Urton Anderson, John Robinson, Dain Donelson, John McInnis, and Tom Sager.

I am also very grateful for my doctoral cohort: Lisa De Simone, Bridget Stomberg, and Laura Wang. I am a direct beneficiary of their wit, curiosity, collegiality, and caring. They helped me learn more than I would have otherwise, and they are just fun to be around. I have gained lifelong friends.

Thank you to the Institute of Internal Auditors for providing the data for this project. Thank you to Patrick Badolato for assistance with BoardEx data. Thank you to the AICPA and supporting firms for providing funding through the Accounting Doctoral Scholars Program. Also, thank you to the Dora Bonham Memorial Fund and the University of Texas at Austin for financial assistance.

I thank my family and extended family from Houston and Beaumont. Their encouragement and support for my family and me has set us up well. They have been instrumental in my achievements and more importantly, the health of my family. 
Finally, and most importantly, I am grateful for my wife, Kimberly, and our three kids. Their support, encouragement, and motivation helped push me through. I love you all. Kim, I am thankful this dissertation did not have to be typed on the typewriter. I am sure you are thankful too. 


\title{
Does Internal Audit Function Quality Deter Management Misconduct?
}

\author{
Matthew Stephen Ege, Ph.D. \\ The University of Texas at Austin, 2013
}

Supervisors: Urton Anderson and John Robinson

\begin{abstract}
Standard-setters believe high-quality internal audit functions (IAFs) serve as a key resource to audit committees for monitoring senior management. However, regulators do not enforce IAF quality or require disclosures relating to IAF quality, which is in stark contrast to regulatory requirements placed on boards, audit committees, and external auditors. Using proprietary data, I find that a composite measure of IAF quality is negatively associated with the likelihood of management misconduct even after controlling for board, audit committee, and external auditor quality. A difference-indifferences analysis suggests that misconduct firms improve IAF quality after misconduct is revealed by increasing IAF competence. Finally, IAF quality is a predictor of accounting-related management misconduct even after controlling for other observable predictors of misconduct. These findings suggest that regulators and audit committees should consider ways to improve IAF quality and that investors would benefit from disclosures relating to IAF quality.
\end{abstract}




\section{Table of Contents}

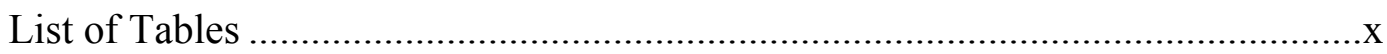

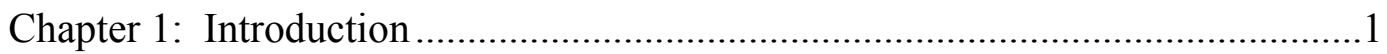

Chapter 2: Background, Related Literature, and Hypotheses Development ............8

2.1 Governance Related Reforms of the Early 2000s...................................

2.2 Background on Internal Audit and IAF Quality as Defined by Standard-

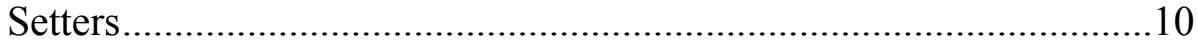

2.3 Related Literature and Hypothesis Development ……….....................12

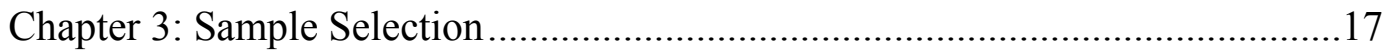

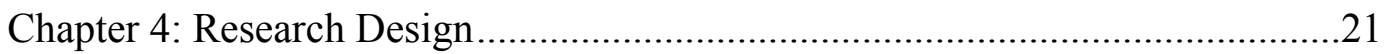

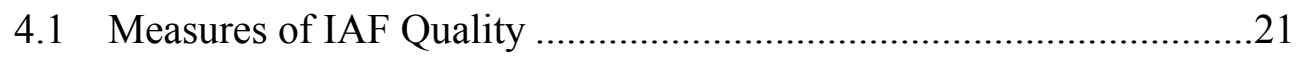

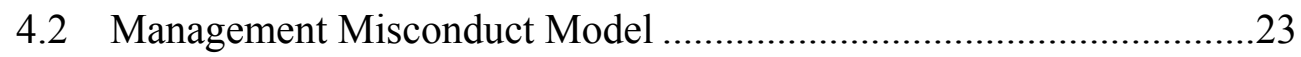

4.3 Response by Misconduct Firms .........................................................29

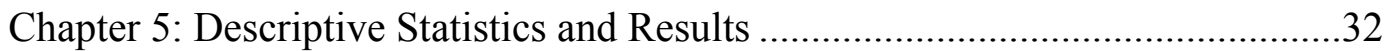

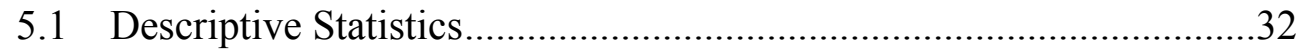

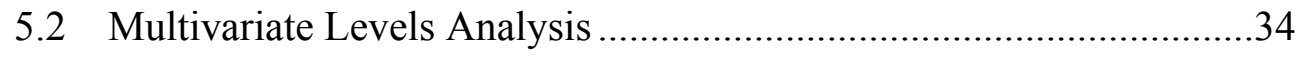

5.3 Response by Misconduct Firms ..........................................................36

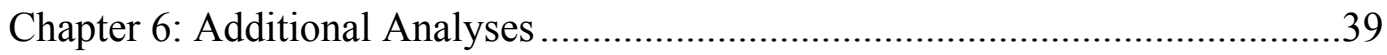

6.1 Accounting- and Non-Accounting-Related Management Misconduct39

6.2 Predicting Accounting-Related Management Misconduct ....................41

Chapter 7: Robustness Tests and Exploratory Analyses...........................................44

7.1 Interaction of Competence and Objectivity .........................................4

7.2 Time-Period Analyses.......................................................................... 45

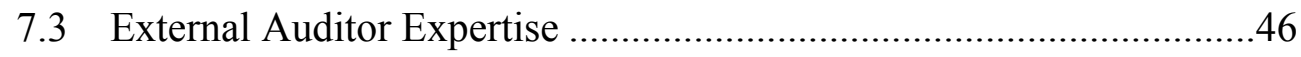

7.4 Controlling for Material Weaknesses in Internal Control over Financial Reporting.................................................................................48

7.5 Response by Misconduct Firms - Supplemental Analysis ...................49

7.6 Controlling for the Extent of IAF Outsourcing.....................................50 
7.7 Controlling for the Financial Focus of the IAF 51

7.8 Instrumental Variables Approach ....................................................53

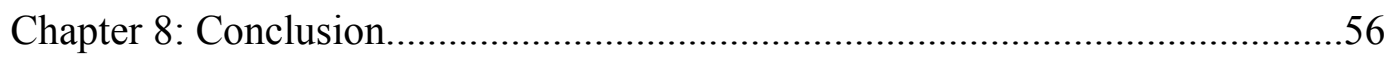

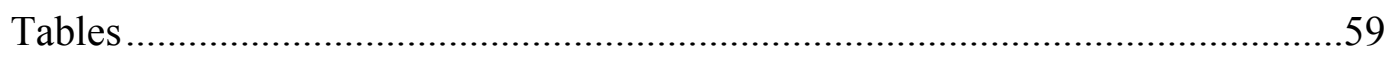

Appendix A - Variable Definitions ......................................................... 100

Appendix B - Selected Portions of the Global Auditing Information Network Survey 103

Appendix C - IAF Quality Factor Loadings................................................. 113

Appendix D - F-score Coefficient Regression ...........................................114

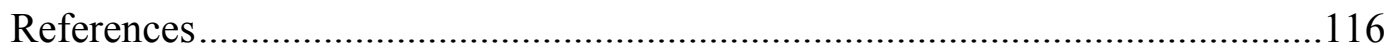




\section{List of Tables}

Table 1, Panel A: Response Frequency of Firms..................................................59

Table 1, Panel B: Firm-Years by Industry ...........................................................60

Table 1, Panel C: Comparison of Governance Outcomes ......................................61

Table 1, Panel D: Sample Descriptive Statistics......................................................62

Table 1, Panel E: Sample Descriptive Statistics by Misconduct ............................63

Table 1, Panel F: Misconduct by Year, 2000 - 2009 ..............................................65

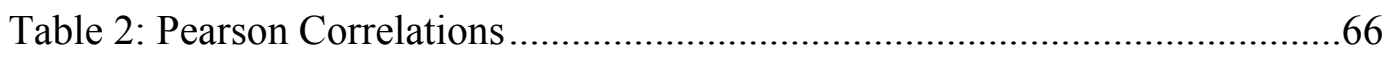

Table 3, Panel A: Effect of IAF Quality on Management Misconduct ..................67

Table 3, Panel B: Average Marginal Effects of IAF Quality on Management

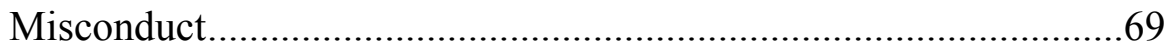

Table 4: Misconduct Firm Response to Revealed Management Misconduct........71

Table 5, Panel A: Effect of IAF Quality on Accounting-Related Management

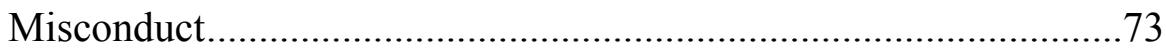

Table 5, Panel B: Effect of IAF Quality on Non-Accounting-Related Management

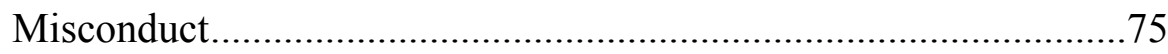

Table 6: Predictive Ability of IAF Quality on Accounting-Related Management

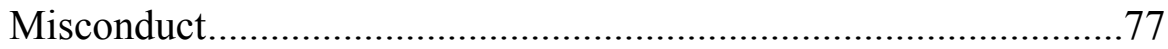

Table 7: Interactive Effect of IAF Competence and Objectivity on Management

Misconduct....................................................................................

Table 8, Panel A: Effect of IAF Quality on Management Misconduct for 2000 - 2001

Table 8, Panel B: Effect of IAF Quality on Management Misconduct for 2000 - 2003 
Table 8, Panel C: Effect of IAF Quality on Management Misconduct for 2000 - 2005 .85

Table 8, Panel D: Effect of IAF Quality on Management Misconduct for 2002 - 2009

Table 9: Effect of IAF Quality on Management Misconduct Controlling for Different External Auditor Quality Definitions. 89

Table 10: Effect of IAF Quality on Management Misconduct Controlling for Internal Control Quality 91

Table 11: Changes in IAF Quality Characteristics in Response to Revealed Management Misconduct. .93

Table 12: Effect of IAF Quality on Management Misconduct Controlling for IAF

Outsourcing...... .94

Table 13, Panel A: Effect of IAF Quality on Accounting-Related Management Misconduct Controlling for IAF Focus. .96

Table 13, Panel B: Effect of IAF Quality on Non-Accounting-Related Management Misconduct Controlling for IAF Focus .98 


\section{Chapter 1: Introduction}

This study examines the relation between internal audit function (IAF) quality, as defined by standard-setters, and the likelihood of management misconduct, such as financial reporting fraud, bribery, and misleading disclosure practices. Standard-setters posit that IAFs serve as a key resource to audit committees for monitoring senior management and that high-quality IAFs, those that are competent and objective, are a deterrent of management misconduct (AICPA 2008; AICPA 2005; COSO 2012; IIA 2012). However, U.S. regulators do not enforce IAF quality or require disclosures relating to IAF quality. ${ }^{1}$ This treatment is in stark contrast to the regulatory requirements placed on other corporate monitors who play a role in monitoring management, such as boards of directors, audit committees, and external auditors.

In response to major accounting scandals such as Enron and WorldCom, regulators placed additional requirements on boards of directors, audit committees, and external auditors to improve the quality of each with respect to monitoring management. These requirements include a majority of independent directors, a fully independent audit committee, disclosure of audit committee financial expertise, and audit committee responsibility for hiring and firing the external auditor. Regulators also established an external auditing regulator that enforces external auditing standards and proactively ensures audit quality. An overarching goal of these requirements was to improve

\footnotetext{
${ }^{1}$ An exception to this is banking regulators. These regulators require audit committees of U.S. banks to oversee the IAF and evaluate its performance and encourage directors to ensure the IAF complies with internal auditing standards (OCC 2003).
} 
corporate governance in order to reduce the likelihood of major accounting scandals (SEC 2003d).

Despite being a cornerstone of corporate governance, regulators did not pass requirements that directly improved IAF quality. The U.S. Securities and Exchange Commission (SEC) proposed requirements that would have increased IAF quality by adding the appointment, compensation, retention and oversight of the internal auditor to audit committee responsibilities, but these proposed requirements were abandoned (SEC 2003c). More recently, NASDAQ proposed requiring listed firms to have an IAF that is overseen by the audit committee, and the SEC is scheduled to make a final ruling on the proposal in June 2013 (SEC 2013). These proposals demonstrate the need for evidence regarding whether IAF quality results in an improved ability of the IAF to monitor management. The results of this study inform standard-setters, regulators, audit committees, and shareholders about whether IAF quality deters management misconduct incrementally to board of director, audit committee, and external auditor quality.

Using proprietary internal audit survey data from the Institute of Internal Auditors, I create a composite measure of IAF quality that captures IAF experience, certification, training, use as a management training ground, reporting relationship with the audit committee, and size (Messier et al. 2011; Prawitt et al. 2009). I also employ a factor analysis to create measures of IAF competence and objectivity, two components of IAF quality recognized by standard-setters (AICPA 1997; IAASB 2012; IIA 2012; PCAOB 2010). Competence includes the knowledge and skills required to perform job responsibilities, while objectivity refers to an unbiased mental attitude towards audit 
matters (IIA 2012). I then test whether IAF quality, competence, and objectivity are associated with observable instances of management misconduct, defined as credible allegations of intentional illegal acts by executive management such as fraud and illegal bribery. These data come from (1) SEC or Department of Justice enforcement actions claiming fraud, intentional misconduct, or illegal bribery under the bribery provision of the Foreign Corrupt Practices Act of 1977 and (2) settled securities class-action lawsuits.

Based upon a final sample of 1,398 firm-years representing 617 unique firms from 2000 through 2009, I find a negative relation between IAF quality and management misconduct, even after controlling for other determinants of misconduct including board of director, audit committee, and external auditor quality. Holding all other variables at their means, a one standard deviation increase in the IAF quality measure represents a 0.5 percentage point decrease in the likelihood of management misconduct, which is a 29.7 percent decrease compared to the base rate of 1.6 percent. Further analysis reveals that IAF competence, but not objectivity, is negatively related to the likelihood of management misconduct, suggesting that IAF competence is at least as important as objectivity in deterring management misconduct.

To help allay endogeneity concerns, I investigate how firms respond to revealed misconduct. Misconduct firms take action to improve corporate governance after revealed misconduct (Farber 2005). If boards of directors, and others who participate in the governance process, believe IAF quality serves as a deterrent of management misconduct, then misconduct firms should respond to revealed misconduct by increasing IAF quality. For example, after illegally marketing two drugs, Amgen entered into a 
Corporate Integrity Agreement with the Office of Inspector General, which included an agreement to establish a healthcare compliance internal audit program composed of an annual risk-based audit plan, audits performed by competent internal auditors, and oversight of corrective actions (OIG 2012; Pollack and Secret 2012). Utilizing a difference-in-differences approach, I find that misconduct firms have low IAF quality and IAF competence during misconduct years as compared to a matched sample of firms. Then, in post-misconduct years, results are consistent with misconduct firms increasing IAF quality by increasing IAF competence. Further analysis suggests that this increase in IAF competence is due to hiring more experienced and certified internal auditors. However, misconduct firms do not appear to have lower IAF objectivity during or after misconduct years as compared to a matched sample. Consistent with the levels regression analysis, these results suggest that IAF quality, and specifically IAF competence, is an important deterrent of management misconduct. Overall, these results are consistent with the proposition from standard-setters that IAFs serve as a key resource for audit committees in their role of monitoring management.

In additional analysis I examine the effect of IAF quality on accounting and nonaccounting-related misconduct separately. My findings suggest that high-quality IAFs are effective at deterring both types of management misconduct. This finding is particularly important because, whereas external auditors focus on accounting-related management misconduct, internal auditors provide assurance related to both accounting- and nonaccounting-related management misconduct (Chadwick 2000; COSO 2012). 
Next, I investigate the ability of IAF quality to predict accounting-related management misconduct. External stakeholders such as investors generally lack information related to the IAF. Survey and experimental research report that disclosure of information related to the IAF would increase stakeholder confidence in governance quality and potentially affect investment decisions (Archambeault et al. 2008; Holt and DeZoort 2009). I find that IAF quality is negatively associated with accounting-related management misconduct even after controlling for observable predictors of accountingrelated management misconduct (see Dechow et al. 2011). This suggests that disclosures related to IAF quality would assist stakeholders in predicting accounting-related management misconduct.

This study contributes to the literature by providing empirical evidence that IAF quality deters management misconduct. Prior studies suggest that the existence of an IAF could deter management misconduct, and there is mixed evidence as to whether IAF quality lowers accounting risk (e.g., Beasley et al. 2000; Christ et al. 2012; Prawitt et al. 2012). I extend this literature by showing that IAF quality and IAF competence are important in deterring observable instances of management misconduct, both accountingand non-accounting related, even after controlling for the effects of board of director, audit committee, and external auditor quality. These findings are important because in the early 2000s regulators responded to public outcry over observable management misconduct yet IAF quality was largely left out of the regulatory debate and reforms that followed. This paper also contributes to the governance literature that studies firm governance changes in response to management misconduct. This study is also the first to 
provide direct empirical support of the important role IAF quality, and specifically IAF competence, play in deterring management misconduct.

From a policy perspective, my findings provide important insights to regulators. Results are consistent with standard-setters' assertions that IAFs improve corporate governance by assisting audit committees in monitoring management. Additionally, my results suggest that disclosures relating to IAF quality would be informative to investors. These findings are especially important given anecdotal evidence that IAF quality is low for some firms. For example, in a recent survey of public-company audit committee members, a NASDAQ audit committee member stated, "The director of internal audit 'technically' reports to the audit committee chair. In reality, he reports to the CEO" (Beasley et al. 2009, 101). This suggests IAF objectivity could be impaired. Similarly, there are recent SEC enforcement actions that implicate the IAF in aiding management in committing misconduct (e.g., SEC 2012a; SEC 2012b; SEC 2012c). Additionally, experimental and anecdotal evidence suggests that the internal audit profession does not attract the most competent employees (Burton et al. 2012; Ernst \& Young 2007). Regulators, audit committees, and the internal auditing profession should consider ways to increase IAF competence, especially given that my results suggest that hiring competent internal auditors is, at a minimum, just as important as objectivity. This paper also informs the debate relating to the recently released NASDAQ proposal that would require listed firms to have an IAF and for the audit committee to take sole responsibility for the IAF (SEC 2013). These new requirements directly address IAF objectivity. My 
study suggests that IAF competence should also be considered as part of the NASDAQ proposal. 


\section{Chapter 2: Background, Related Literature, and Hypotheses Development}

2.1 Governance Related Reforms of the Early 2000s

In response to egregious accounting frauds at firms such as Enron and WorldCom, the U.S. Congress passed the Sarbanes-Oxley Act of 2002, which included corporate governance reforms that affected audit committees and external auditors (Lucas 2004). The Sarbanes-Oxley Act of 2002 created the Public Company Accounting Oversight Board, which oversees external auditors and requires compliance with external auditing standards. The Sarbanes-Oxley Act of 2002 also required the SEC to codify audit committee requirements such as member independence, disclosure of financial expertise, and the responsibility to select and oversee the external auditor. The SEC proposed these requirements and also requested comment on whether the appointment, compensation, retention and oversight of the internal auditor should be part of the audit committee's responsibilities. However, the SEC abandoned the latter propositions stating the majority of commenters did not support them (SEC 2003c). ${ }^{2}$ As a result, there are no SEC requirements that directly enforce IAF quality.

Also, in response to the high-profile corporate failures in the early 2000 s, then SEC Chairman, Harvey Pitt, requested the New York Stock Exchange and NASDAQ to review the corporate governance requirements for listed companies. Subsequently, both

\footnotetext{
${ }^{2}$ In fact, the majority of commenters did not comment at all on the IAF-related propositions. Commenters that supported the proposal include the Institute of Internal Auditors, the American Institute of Certified Public Accountants, the National Association of Corporate Directors, and the California Public Employees' Retirement System. However, the New York Stock Exchange, Financial Executives International, PricewaterhouseCoopers, and Deloitte \& Touche did not support the proposal (SEC 2003a). Commenters who did not support the proposal usually cited as reasons either (1) an already over-burdened audit committee or (2) an unintentional consequence of eroding management's sense of ownership for internal controls.
} 
exchanges implemented several changes to governance requirements for listed firms including strengthening audit committee independence requirements, requiring a majority of the board to be comprised of independent directors, and making the audit committee responsible for the appointment, compensation, retention, and oversight of the external auditor. The New York Stock Exchange also added the requirement to have an IAF and now requires the audit committee to periodically meet privately with management, internal auditors, and external auditors (SEC 2003d). ${ }^{3}$ Overall, the SEC stated that these changes were designed, among other things, "to prevent fraudulent and manipulative acts and practices" (SEC 2003d). However, these requirements do not stipulate minimum requirements for IAFs or require ongoing evaluations of the IAF (Protiviti 2007).

From a practical standpoint, external auditors likely enforce some level of IAF quality on all firms subject to internal control audits. If an external auditor believes the IAF is of insufficient quality, then they can issue a material weakness in internal controls over financial reporting. ${ }^{4}$ Also, in order to comply with banking regulatory standards, audit committees for U.S. banks are required to oversee and evaluate the performance of the IAF, and bank directors are encouraged to ensure their IAFs are following internal

\footnotetext{
${ }^{3}$ In 2013 NASDAQ proposed requiring all firms to have an IAF and that the audit committee will have sole responsibility to oversee the IAF (SEC 2013). The NASDAQ proposal also states that the proposed rule change is, among other things, designed to "prevent fraudulent and manipulative acts and practices".

${ }^{4}$ Based upon a query on November 29, 2012, Audit Analytics identified 85 auditor internal control opinions citing material weaknesses in internal control over financial reporting caused by an ineffective IAF. Additionally, Auditing Standard No. 2 explicitly states that for large and complex companies an ineffective IAF is at least a significant deficiency and is a strong indicator of a material weakness in internal control over financial reporting (PCAOB 2004).
} 
auditing standards (OCC 2003). ${ }^{5}$ While U.S. banking regulators passed requirements that improve IAF quality, the SEC, New York Stock Exchange, and NASDAQ have not. Therefore, IAF quality for U.S. firms is left largely up to audit committees and management.

The combined oversight of the IAF by the audit committee and management is often informal, sometimes contentious, and lacks clarity (Beasley et al. 2009). After interviewing 42 audit committee members, Beasley et al. (2009) conclude: "There is significant potential for internal audit's loyalties to be divided as a result of multiple reporting channels." Managers intending to commit misconduct will have more opportunity to do so if they can also control IAF quality. Therefore, it is somewhat surprising that IAFs are unregulated, particularly when compared to regulatory requirements placed on boards, audit committees, and external auditors. Interestingly, NASDAQ has recently proposed that all listed firms would be required to not only have an IAF, but that this IAF would be the sole responsibility of the audit committee (SEC 2013).

2.2 Background on Internal Audit and IAF Quality as Defined by Standard-Setters The Institute of Internal Auditors defines internal auditing as "an independent, objective assurance and consulting activity designed to add value and improve an organization's operations" (Reding et al. 2009). Internal auditors help organizations achieve business objectives by improving the effectiveness of risk management, control,

\footnotetext{
${ }^{5}$ The Board of Governors of the Federal Reserve System issued a policy statement in 2013 that further encourages regulated institutions to comply with the internal auditing standards issued by the Institute of Internal Auditors (Board of Governors of the Federal Reserve System 2013).
} 
and governance processes and are a valuable source of information for audit committees, external auditors, and managers (Gramling et al. 2004; Protiviti 2007). Internal auditors serve as the "eyes and ears" of the audit committee and are able to deter management misconduct by effectively being able to detect management misconduct (AICPA 2005). "Fear of getting caught is always a strong deterrent" (AICPA 2008, 30). Internal auditors test controls throughout the organization and focus their efforts on areas with the highest risk. For example, at Lord Corporation, the IAF reviews all high-risk areas of the financial close process each year (FERF 2013). Internal auditors play a key role in monitoring compliance with laws and regulations such as with the Foreign Corrupt Practices Act of 1977 (Birk 2010; Tabuena 2010). Also, the IAF itself serves as an important control. For example, the chief audit executive (i.e., the head of the internal audit department) at IBM sits on the disclosure committee, helping to ensure the quality of disclosures (FERF 2013).

In addition to other responsibilities, internal auditors must consider the probability of fraud (IIA 2012). However, unlike external auditing standards, which focus only on fraud related to material misstatement of financial statements, fraud in internal auditing standards is broadly defined as: "Any illegal act characterized by deceit, concealment, or violation of trust...Frauds are perpetrated by parties and organizations to obtain money, property, or services; to avoid payment or loss of services; or to secure personal or business advantage" (IIA 2012, 20). Thus, in addition to fraud that results in a material misstatement in financial statements, IAFs are tasked with considering management misconduct that may not result in materially misstated financial statements such as 
bribing foreign officials and intentionally misleading disclosures. A strong IAF should be able to identify situations where management overrides controls or acts unethically, and thus, should serve as a deterrent for accounting- and non-accounting-related management misconduct (Chadwick 2000; COSO 2012).

Both external and internal auditing standards posit that a competent and objective IAF can positively affect financial reporting quality (AICPA 1997; IAASB 2012; IIA 2012; PCAOB 2010). ${ }^{6}$ Competence refers to the "knowledge, skills, and other competencies needed to perform...responsibilities" (IIA 2012, 5), while objectivity refers to "an unbiased mental attitude that allows internal auditors to perform engagements in such a manner that they believe in their work product and that no quality compromises are made" (IIA 2012, 3). A competent and objective IAF is better able to detect management misconduct, and as such is one of the strongest management misconduct deterrents (AICPA 2008).

\subsection{Related Literature and Hypothesis Development}

Two studies provide initial evidence that IAFs can deter management misconduct. First, Beasley et al. (2000) investigate a sample of 66 SEC Accounting and Auditing Enforcement Releases issued during 1987 through 1997 and report that the firms with Accounting and Auditing Enforcement Releases were less likely to have IAFs than a benchmark of non-fraud firms. Second, in an experimental setting, Schneider and Wilner (1990) report that the existence of an IAF serves as a deterrent to financial reporting

\footnotetext{
${ }^{6}$ Internal auditing standards use the term "proficiency" instead of "competence" (see IIA 2012, Attribute Standard 1210).
} 
irregularities under certain conditions. ${ }^{7}$ These studies suggest that the existence of an IAF deters management misconduct, but do not address whether the quality of the IAF has an effect on the likelihood of management misconduct. In addition, my study extends these studies by investigating the IAF's contribution to deterring management misconduct incremental to board, audit committee, and external auditor quality. This is important because there have been many changes to the requirements for boards, audit committees, and external auditors since 2000 .

There is also an emerging literature that investigates the effect of IAF quality on financial reporting quality. Prawitt et al. (2009) find that IAF quality is unrelated to positive abnormal accruals, but positively related to negative abnormal accruals, which is consistent with high-quality IAFs limiting big-bath behavior by management. Prawitt et al. (2009) also find that firms that just miss their analysts' consensus forecast have higher IAF quality compared to firms that just made their analysts' consensus forecast and compared to all other firms. However, they find no difference in IAF quality between firms that just made their analysts' consensus forecast and all other firms (i.e., firms that did not just miss or just make their analysts' consensus forecast).

Firms that use the IAF as a management training ground are associated with higher accounting risk and higher external auditor fees, conceivably because IAF

\footnotetext{
${ }^{7}$ Specifically, Schneider and Wilner (1990) provided cases to 264 participants, who made decisions in a situation with no auditing, with only internal auditing, or with only external auditing. The cases also varied on the following factors: materiality, type of irregularity, perceived extent of Generally Accepted Accounting Principles violation, and managerial incentives for misstating income. Schneider and Wilner (1990) report that the existence of a competent IAF serves as a deterrent to financial reporting irregularities, as compared to a condition with no internal or external audits, when all of the following conditions are met: material dollar amounts, irregularities involving asset overstatement, unambiguous violation of Generally Accepted Accounting Principles, and managers having lower incentives for misstating income.
} 
objectivity is impaired when the IAF is used as a management training ground (Christ et al. 2012; Messier et al. 2011). While not a focus of either paper, Christ et al. (2012) find evidence that IAF quality is unassociated with accounting risk and CEO total compensation, but Prawitt et al. (2012) find some evidence that IAF quality is negatively associated with accounting risk.

This study builds on this prior literature in several ways. First, I focus on whether high-quality IAFs improve financial reporting quality directly related to intentional management misconduct. Proxies for earnings management such as discretionary accruals have little or no correlation with observable instances of intentional management misconduct (Price et al. 2011). Additionally, it is possible that IAF quality is associated with improved financial reporting quality because a high-quality IAF does a better job at ensuring strong internal controls. Strong internal controls over financial reporting have been linked to a reduction in financial reporting errors, but not a reduction in intentional misstatements by management (e.g., Ashbaugh-Skaife et al. 2008). Secondly, this is the first study to separately examine the effects of IAF competence and objectivity on management misconduct. This is important because there is anecdotal evidence that both IAF objectivity and competence are low for some firms (e.g., Beasley et al. 2009; Ernst \& Young 2007). Third, this is the first study to consider the IAF's role in deterring both accounting- and non-accounting-related management misconduct.

Standard-setters also recognize that internal auditors can deter management misconduct. Although the audit committee has the primary responsibility of monitoring senior management, IAFs serve as a key resource to audit committees in this task 
(AICPA 2008; AICPA 2005; COSO 2012). Additionally, external auditing standards state that an effective IAF can constrain management misconduct (AICPA 2007). Therefore, while there is scant direct evidence that IAF quality deters management misconduct, there is good reason to believe high-quality IAFs serve as a deterrent to management misconduct.

While there are strong reasons to suspect that IAF quality should deter management misconduct, there is some literature that suggests otherwise. Uecker et al. (1981) posited that perceived internal auditor aggressiveness would deter managers from committing management fraud. However, they found no evidence of this and concluded "managers contemplating acts of management fraud are not deterred by the presence of internal...auditors" (Uecker et al. 1981, 478). Also, there is evidence that internal auditors report lower-levels of management fraud risk when reporting directly to the audit committee as opposed to management. In an experimental setting internal auditors reduced assessed levels of management fraud risk more (less) when reporting directly to the audit committee (management) because of fear of “'over-reaction' by the audit committee and reprisals from management" (Norman et al. 2010, 549). Thus, a reporting line to the audit committee without protection from management reprisals (e.g., having the audit committee control the appointment and remuneration of the chief audit executive) potentially creates unintended independence problems.

I state the following hypotheses in the alternative form.

H1: Internal audit function quality is negatively associated with the likelihood of management misconduct. 
H2: Internal audit function competence is negatively associated with the likelihood of management misconduct.

H3: Internal audit function objectivity is negatively associated with the likelihood of management misconduct. 


\section{Chapter 3: Sample Selection}

I obtain my initial sample from the Institute of Internal Auditors' Global Auditing Information Network database, a proprietary database. This database includes survey responses from chief audit executives associated with the Institute of Internal Auditors and has been used in a small number of prior archival internal audit papers (e.g., Prawitt et al. 2009; Lin et al. 2011; Prawitt et al. 2012). The Institute of Internal Auditors provided the data, including company names, on conditions of anonymity and confidentiality. Firm names were unavailable for years 2000 through 2003. To identify firms in these years I first utilized Global Auditing Information Network database company identifiers from subsequent years (i.e., I checked to see if any company identifiers from 2000 through 2003 matched identifiers from subsequent years). Then, for the remaining unidentified firm-years from 2000 through 2003 I utilized a matching procedure similar to prior research (e.g., Prawitt et al. 2009; Lin et al. 2011; Prawitt et al. 2012). Specifically, I matched self-reported total assets, revenue, and employees to associated fields in Compustat.

Firms that respond to the Institute of Internal Auditors' survey do so because they are then provided with benchmarking data which they can use to compare their IAF to industry practices. Therefore, it is likely that the firms that self-select into my sample have higher IAF quality on average than the rest of the population of firms. This produces a bias against finding results consistent with my hypotheses because poorly governed firms are likely those that do not respond to the survey and that are more likely to have management misconduct. My sample covers 2000 through 2009. Following Prawitt et al. 
(2009) I remove firm-years with nonsensical values. These include the percentage of certified public accountants, certified internal auditors, or certified fraud examiners greater than 100 percent, reported average training hours greater than 160 , time spent providing direct assistance to the external auditors greater than 100 percent, and reported average internal audit experience greater than 30 years. ${ }^{8}$

To obtain a management misconduct sample, I utilize four data sources. First, I gather SEC and Department of Justice enforcement actions that allege fraud or other intentional misconduct from the Federal Securities Regulation Database. ${ }^{9}$ Second, I gather settled securities class-action lawsuits from Stanford Securities Class Action Clearinghouse. ${ }^{10}$ I specifically exclude lawsuits that were dismissed because the plaintiffs in these cases were unable to convince the judge that there was fraudulent intent. Third and fourth, I obtain SEC and Department of Justice enforcement actions claiming violations of the foreign bribery provisions of the Foreign Corrupt Practices Act of 1977 from the SEC's and Department of Justice's web sites. ${ }^{11}$

I include control variables related to board of director, audit committee, and external auditor quality as well as to other determinants of misconduct. Data for these control variables come from BoardEx, Compustat, Corporate Library, and Thompson

\footnotetext{
${ }^{8} 11$ firm-years are lost because of removing firm-years with nonsensical values. Inferences remain the same if these firm-years are included within the analysis.

${ }^{9}$ For more information on these data see http://www.fesreg.com/. These data were hand-collected by Jerry Martin and initially used in Karpoff et al. (2008a and 2008b).

${ }^{10}$ For more information on these data see http://securities.stanford.edu/index.html.

${ }^{11}$ For more information on these data see http://www.sec.gov/spotlight/fcpa/fcpa-cases.shtml and http://www.justice.gov/criminal/fraud/fcpa/cases/a.html.
} 
Reuters. My final sample includes 1,398 firm-years from 617 unique firms from years 2000 through 2009.

Panel A of Table 1 presents the response frequency of the firms. Over 50 percent of the firms respond only one time during the sample time period. Thus, it appears that many firms respond to the Global Auditing Information Network survey to benchmark their IAF against their industry peers and then do not respond again for several years. Panel B of Table 1 presents the breakdown of firm-year responses by industry and reports misconduct rates and average IAF quality. The computer, software, and electronic equipment industry and the healthcare, medical equipment, and drugs industry have the highest rate of misconduct in the sample. Not surprisingly, the utility and finance industries have the highest average IAF quality. The consumer durables and manufacturing industries have the lowest average IAF quality. ${ }^{12}$

To compare the overall quality of governance and reporting between firms that responded to the Global Auditing Information Network survey and firms that did not, I match each sample firm-year to a firm-year from a firm that did not respond to the Global Auditing Information Network survey during the sample period based upon industry (i.e., Fama-French 12 industry classification), year, and closest market capitalization. I then test differences in discretionary accruals, rates of material weaknesses in internal control, and accounting management misconduct. ${ }^{13}$ Table 1 Panel $\mathrm{C}$ presents the results. There

\footnotetext{
${ }^{12}$ I include industry fixed effects in the regression analyses in Chapter 4. However, results are robust if I exclude industry fixed effects from these analyses.

${ }^{13}$ Accounting management misconduct are violation years from the Federal Securities Regulation Database where fraud is alleged. I do not compare rates of settled securities class action lawsuits or violations of the
} 
are no statistical differences for signed discretionary accruals and income-decreasing discretionary accruals between the sample and matched firm-years. This suggests that governance and reporting quality is similar between firms that responded to the Global Auditing Information Network survey and firms that did not. Sample firms have lower income-increasing discretionary accruals as compared to matched firms with a p-value that is less than five percent. This is consistent with firms that select into the sample having better financial reporting quality. However, sample firm-years have a higher rate of material weaknesses in internal control ( $\mathrm{p}$-value of less than one percent) and accounting management misconduct (p-value of less than five percent) as compared to matched firm-years, which would suggest that sample firms have lower financial reporting quality compared to a matched set of similar firms. Therefore, regarding the overall governance and reporting quality of firms that self-select into the sample, there is mixed evidence as to whether these firms are different than similar firms who do not respond to the Global Auditing Information Network survey.

bribery provisions of the Foreign Corrupt Practice Act of 1977 because these data are collected by hand, whereas data from the Federal Securities Regulation Database are machine readable. 


\section{Chapter 4: Research Design}

\subsection{Measures of IAF Quality}

Internal and external auditing standards identify competence and objectivity as key components of auditor quality (AICPA 1997; IAASB 2012; IIA 2012; PCAOB 2010). These standards consider internal auditor professional experience, professional certifications, and training as evidence of competence. I define EXPERIENCE as the average number of years of internal auditing experience of internal auditors in the IAF; CERTIFICATION as the percentage of internal auditors in the IAF who have the Certified Internal Auditor (CIA), Certified Public Accountant (CPA), or Certified Fraud Examiner (CFE) certifications; and TRAINING as the average number of hours of training internal auditors in the IAF completed during the year. ${ }^{14} \mathrm{I}$ then create dichotomous variables for each by assigning a value of one to the variable if it is above the median of my sample, and zero otherwise. These variables are EXPERIENCE_IND, CERTIFICATION_IND, and TRAINING_IND, respectively.

Auditing standards state that auditor independence affects auditor objectivity. Thus, I set INDEPENDENT to one if the IAF functionally reports to the audit committee, and zero otherwise. Additionally, IAFs that are used as a management training ground are perceived as less objective by external auditors (Messier et al. 2011). Thus, I set

\footnotetext{
${ }^{14}$ Appendix B includes questions from the Global Auditing Information Network survey that were used to calculate these variables.
} 
NOT_TRAINING_GROUND to one if the IAF is not used as a management training ground, and zero otherwise. ${ }^{15}$

To capture a firm's overall IAF investment, I create an IAF size measure similar to Prawitt et al. (2009). I first calculate the dollar amount spent on internal auditing per company in year $t$ divided by the company's total sales at the end of year $t$. IAF_SIZE is calculated by subtracting the industry average of this ratio from the firm-specific ratio and then dividing this amount by the industry-average of the ratio of dollar amount spent on internal auditing to sales. ${ }^{16}$ I then create a dichotomous variable, IAF_SIZE_IND, which is equal to one if $I A F \_S I Z E$ is positive, and zero otherwise. I expect better funded IAFs to be more effective at monitoring management because they have more resources at their disposal.

Finally, I create a comprehensive IAF quality measure similar to Prawitt et al. (2009). QUALITY is the sum of EXPERIENCE_IND, CERTIFICATION_IND, TRAINING_IND, NOT_TRAINING_GROUND, INDEPENDENT, and IAF_SIZE_IND.

\footnotetext{
${ }^{15}$ For years 2000 through 2005 the Global Auditing Information Network survey asks participants "Are staff auditors encouraged to make their auditing careers?" with a possible response being "Rotational / prepare for other areas of the company". I set NOT_TRAINING_GROUND to zero for firm-years when this response is given and to one when other responses are selected (other available responses were "mostly rotational in the past but company changing to career auditors", "career", and "career but moving towards rotational"). The Global Auditing Information Network survey also captures the percentage of professional staff turnover that was placed inside the company. For years 2000 through 2005 this percentage was 15.6 percent for firm-years where the IAF was used as a management training ground. Therefore, for years 2006 through 2009, I set NOT_TRAINING_GROUND to zero for firm-years where the percentage of professional staff turnover that was placed inside the company was greater than 15.6 percent. Inferences remain the same if I exclude from my sample years 2006 through 2009.

${ }^{16}$ The formula for this calculation is as follows: [(firm IAF budget / firm sales) - (industry average of firm IAF budget / firm sales)] / (industry average of firm IAF budget / firm sales). I use the Fama-French 12 industry classification. The number of firm-years by industry ranges from 34 to 245 with an average of 117 and a median of 97.
} 
QUALITY ranges from zero to six with larger numbers indicating better overall IAF quality.

I also create measures of IAF competence and objectivity by using a principal components factor analysis that extracts common variation among the six measures of IAF quality. I first standardize each measure to have a mean of zero and a standard deviation of one. The factor analysis identified two factors with eigenvalues greater than one, which collectively explain approximately 44 percent of the underlying variance. The standardized scoring coefficients from the factor analysis are presented in Appendix C. The first factor is positively associated with EXPERIENCE, CERTIFICATION, TRAINING, NOT_TRAINING_GROUND, and IAF_SIZE and negatively associated with INDEPENDENT. The strongest factor loadings are for EXPERIENCE and CERTIFICATION, which is consistent with how auditing standard-setters define competence. Therefore, I label this first factor as COMPETENCE. The second factor is negatively associated with EXPERIENCE, CERTIFICATION, and TRAINING and positively associated with NOT_TRAINING_GROUND, INDEPENDENT, and IAF_SIZE. The strongest factor loadings are for INDEPENDENT and IAF_SIZE. Therefore, I label this second factor as OBJECTIVITY.

\subsection{Management Misconduct Model}

My management misconduct model controls for incentives to engage in misconduct, corporate governance variables related to monitoring management, and other determinants of misconduct. Specifically, I control for growth prospects, leverage, audit committee accounting expertise, director independence, external auditor industry 
My coefficient of interest is $\beta_{1}$, which measures the effect of IAF quality. A negative and significant coefficient would be consistent with H1. To test $\mathrm{H} 2$ and $\mathrm{H} 3$, I replace QUALITY with COMPETENCE and OBJECTIVITY. A negative and significant coefficient on COMPETENCE would be consistent with H2. A negative and significant coefficient on OBJECTIVITY would be consistent with $\mathrm{H} 3$.

IAFs are often used by external auditors to perform financial statement audit tasks. External auditors predominantly use IAFs for direct assistance for low-risk areas, which are unlikely to have a high risk of management misconduct (AICPA 1997; PCAOB 2010). The extent to which IAFs provide direct assistance to external auditors lowers the time IAFs can spend on other tasks that could deter management misconduct. I define ASSISTS_AUDITOR as the percentage of time the IAF spends assisting the external auditor in year $t$. I do not make a directional prediction for this variable. On the one hand more direct assistance lowers the amount of time IAFs can spend on higher risk areas, which would lead to a positive prediction. However, external auditors cannot rely on IAFs unless they are of high quality, which suggests that ASSISTS_AUDITOR could be negatively related to the likelihood of management misconduct.

I control for governance-related characteristics that affect governance quality and could affect the likelihood of management misconduct. I control for the accounting expertise of the audit committee, as prior literature suggests audit committee accounting expertise improves audit committee effectiveness. ${ }^{17}$ Accounting expertise on the audit

\footnotetext{
${ }^{17}$ The SEC's definition of audit committee financial expertise is broader than just accounting expertise. The SEC originally proposed that only individuals with knowledge of Generally Accepted Accounting Principles obtained through experience as an auditor or accountant would meet the definition of a financial
} 
committee is associated with better financial reporting quality, as measured by better accrual quality and more conservatism (Dhaliwal et al. 2010; Krishnan and Visvanathan 2008). ${ }^{18} A C_{-} A C C O U N T I N G \_E X P$ equals the percentage of audit committee members with accounting expertise in year $t$. Data for this variable come from BoardEx. Accounting expertise is defined as work experience as a public auditor at one of the 25 audit firms listed in Compustat, as a CPA or Chartered Accountant, or in an accountingspecific position, such as Chief Financial Officer, Treasurer, Controller, Head of Accounting, etc. I expect a negative relation between the percentage of audit committee accounting experts and the likelihood of management misconduct. I control for board independence because boards have to have a majority of independent directors and independence is a key tenant of strong monitoring (Beasley 1996; Donelson et al. 2012; Klein 2002; Larcker et al. 2007). I expect a negative relation between the percentage of independent board members and the likelihood of management misconduct. $B R D \_P C T \_I N D$ is equal to the percentage of directors that are independent in year $t$.

I control for chief executive officer duality and chief executive officers who are also the founder of the company. Being the chief executive officer and also either the chairperson of the board of directors or the company founder likely increases the chief

expert. However, because of pressure from various stakeholders, the SEC broadened the definition to include directors who have supervised accountants or served in a role that analyzes financial statements (SEC 2003b). I include the stricter definition of audit committee accounting expertise as opposed to the broader definition of audit committee financial expertise in my main analysis because all but 40 firm-years in my sample have an audit committee who has at least one financial expert as defined by the SEC.

Inferences remain the same if I control for the percentage of audit committee financial experts, as defined by the SEC.

${ }^{18}$ Audit committee accounting and finance expertise is associated with a lower likelihood of internal control weaknesses (Krishnan 2005), and audit committee accounting expertise is valued by market participants as evidenced by a positive stock price reaction when firms disclose the appointment of such experts to the audit committee (DeFond et al. 2005). 
executive officer's influence over company operations and the board of directors (Dechow et al. 1996; Fama and Jensen 1983; Yermack 1996). CEOISCHAIR is equal to one if the chief executive officer is also chair of the board of directors in year $t$, and zero otherwise. I expect a positive relation between chief executive officer duality and the likelihood of management misconduct. CEOFOUNDER is equal to one if the chief executive officer in year $t$ is also the company founder, and zero otherwise. I also expect a positive relation between CEOFOUNDER and the likelihood of management misconduct.

The last two governance-related variables for which I control are institutional ownership and external auditor quality. Large block shareholders with voting rights, such as institutional investors, are incentivized to monitor management, and thus could serve to decrease the likelihood of management misconduct (Beasley 1996; Shleifer and Vishny 1986). INSTITUTIONAL_OWN is the percentage of shares outstanding held by institutional investors at the end of year $t$. I expect INSTITUTIONAL_OWN to be negatively related to the likelihood of management misconduct. I also control for external auditor quality by identifying whether or not firms are audited by an industry-expert external auditor. ${ }^{19}$ AUDITOR_SPECIALIST is equal to one if the external auditor has the highest industry market share for year $\mathrm{t}$, and zero otherwise (Palmrose 1986). ${ }^{20} \mathrm{I}$ expect AUDITOR_SPECIALIST to be negatively related to the likelihood of management

\footnotetext{
${ }^{19}$ I do not use an indicator for the presence of a Big 4 auditor because only 67 sample firm-years do not have a Big 4 auditor. Inferences remain the same if I include an indicator for a Big 4 auditor instead of including AUDITOR_SPECIALIST.

${ }^{20}$ Inferences remain the same if I define industry-expert auditors based upon expertise at the city-level or based upon joint city- and national-level expertise (Francis et al. 2005).
} 
misconduct because industry-expert auditors should provide higher quality external audits as compared to non-expert auditors.

I also control for size, growth prospects, leverage, percentage of foreign sales, and debt and equity offerings. LMARKETCAP is the natural log of market capitalization at the end of year $t . B M$ is the book value of common equity divided by the market value of common equity at the end of year $t$. LEVERAGE is total debt scaled by total assets at the end of year $t$. PCTFORSALES is the percentage of total sales attributable for foreign segments as reported in the Compustat Segments database at the end of year $t$. ISSUE indicates whether a firm issued new debt or equity. It is equal to one when the sum of issued securities during year $t$ is greater than ten percent of total assets at the end of year $t$. When examining relations between these variables and management misconduct, prior research finds a positive relation with firm size, a negative relation with the book-tomarket ratio, a positive (although not always significant) relation with leverage, and a positive relation with security issuance (e.g., Beneish 1999; Dechow et al. 2011). Thus, I expect a positive sign on $L M A R K E T C A P$, a negative sign on $B M$, a positive sign on LEVERAGE, and a positive sign on ISSUE. I include PCTFORSALES within the model because firms with large foreign operations likely have a higher chance of violating the bribery provisions of the Foreign Corrupt Practices Act of 1977 than firms that only operate domestically. This follows because a firm without foreign operations (and presumably without plans to expand internationally) would not have a need to bribe foreign officials. Thus, I expect a negative sign on PCTFORSALES. 


\subsection{Response by Misconduct Firms}

If boards of directors, and others who participate in the governance process, believe IAF quality serves as a deterrent of management misconduct, then misconduct firms should respond to revealed misconduct by increasing IAF quality. Farber (2005) finds that firms that fraudulently manipulated their financial statements improved certain corporate governance characteristics compared to a control sample within three years after fraud detection. In 2012, Amgen entered into a Corporate Integrity Agreement with the Office of Inspector General after illegally marketing two drugs. In this Corporate Integrity Agreement Amgen agreed to establish a healthcare compliance internal audit program composed of an annual risk-based audit plan, audits performed by competent internal auditors, and oversight of corrective actions (OIG 2012; Pollack and Secret 2012). Evidence of an increase in IAF quality for misconduct firms in the years subsequent to management misconduct would provide some causal support for the expected results in equation (1) by suggesting that IAF quality is negatively related to the likelihood of management misconduct due to the belief by firms of the deterring effects of IAF quality and not due to endogenous covariates.

I examine whether IAF quality changes for misconduct firms post misconduct using a difference-in-differences design. I match firm-years from misconduct firms to firm-years from non-misconduct firms based upon year, industry (i.e., Fama-French 12 industry classification), and closest market capitalization. The final sample includes 217 firmyears from misconduct firms, of which 129 are from misconduct years and 88 are from

post-misconduct years, and a matched set of 217 firm-years from firms that never had 
misconduct during the sample period. I estimate the following OLS model:

$$
\begin{aligned}
& \text { QUALITY }_{\mathrm{t}}=\beta_{0}+\beta_{1} \text { MISCONDUCT_FIRM }{ }_{t}+\beta_{2} \text { POST_MISCONDUCT } t_{t}+ \\
& \beta_{3} \text { MISCONDUCT_FIRM }{ }_{t} * P O S T \text { MISCONDUCT } t_{t}+\beta_{4} A S S I S T S \_A U D I T O R_{t}+ \\
& \beta_{5} A C \_ \text {ACCOUNTING_EXP } t_{t}+\beta_{6} B R D_{-} P C T_{-} I N D_{t}+\beta_{7} \text { CEOISCHAIR } \text { t }_{t}+ \\
& \beta_{8} \text { CEOFOUNDER } R_{t}+\beta_{9} \text { INSTITUTIONAL_OWN }{ }_{t}+ \\
& \beta_{10} A \text { ADITOR_SPECIALIST } T_{t}+\beta_{11} \text { LMARKETCAP }_{t}+\beta_{12} \text { BM }_{t}+\beta_{13} \text { LEVERAGE }_{t} \\
& +\beta_{14} \text { PCTFORSALES } S_{t}+\beta_{15} \text { ISSUE }_{t}+\text { Year Fixed Effects }+ \text { Industry Fixed } \\
& \text { Effects }+\varepsilon
\end{aligned}
$$

See Appendix A for detailed variable definitions.

MISCONDUCT_FIRM is an indicator variable that is set to one for observations from a firm that had misconduct during the sample period, and zero otherwise. For example, if firm $i$ had misconduct for years 2003 and 2004 and was in the sample from 2000 through 2009, then MISCONDUCT_FIRM would equal one for all ten firm-years. POST_MISCONDUCT is an indicator variable that is set to one for firm-years from misconduct firms that are subsequent to the violation years (i.e., where MISCONDUCT = 0 for year $t$, but MISCONDUCT $=1$ for year $t-x$ ) and for matched firm-years from the control sample. There are two coefficients of interest. First, $\beta_{1}$ represents the difference in IAF quality during the misconduct years between misconduct firms and the control firms. A negative and significant coefficient on $\beta_{1}$ would suggest that IAF quality for misconduct firms is lower during the misconduct years as compared to the control firms. Second, $\beta_{3}$ represents the difference between misconduct firms and non-misconduct firms in the change of IAF quality from misconduct years to post misconduct years (i.e., it is the difference-in-differences). A positive and significant coefficient on the interaction of MISCONDUCT_FIRM and POST_MISCONDUCT would be consistent with the 
proposition that those in charge of governance at misconduct firms responded to revealed misconduct by improving IAF quality, and that this response was not due to confounding factors.

The remaining variables are defined the same as in equation (1). I expect better governed firms would positively affect IAF quality. Thus, I expect positive coefficients on $A C \_A C C O U N T I N G \_E X P, \quad B R D \_P C T \_I N D$, and INSTITUTIONAL_OWN and negative coefficients on CEOISCHAIR and CEOFOUNDER. I make no predictions for the coefficients on the remaining independent variables. To provide insights into whether misconduct firms increase IAF competence and or objectivity in response to management misconduct, I replace the dependent variable, QUALITY, with COMPETENCE and OBJECTIVITY in subsequent specifications of equation (2). 


\section{Chapter 5: Descriptive Statistics and Results}

\subsection{Descriptive Statistics}

Table 1 Panel D presents descriptive statistics for the variables in equation (1) as well as for the underlying IAF quality measures. The average years of internal auditing experience for the IAFs within my sample is 6.36 years. The average percentage of internal auditors who are professionally certified is 61 percent. This percentage represents four percent, 37 percent, and 20 percent of internal auditors who have the CFE, CPA, and CIA certifications, respectively. Internal auditors spend an average of 52 hours in training each year. For two-thirds of firm-years in my sample the IAF is not used as a management training ground. The IAF functionally reports to the audit committee in approximately 87 percent of the firm-years within my sample. This percentage increases from 2000 through 2009 with a significant increase after the passage of The SarbanesOxley Act of 2002. Specifically, INDEPENDENT is 51 percent in 2000, 58 percent in 2001, 80 percent in 2002, 86 percent in 2003, and above 90 percent for 2004 through 2009.

On average the IAF only spends approximately three percent of their time providing direct assistance to the external auditors. Audit committee accounting expertise is present in about 31 percent of firm-years. On average, the boards in my sample are made up of two-thirds independent directors. The chief executive officer serves as the board chairperson for approximately two-thirds of firm-years, and the chief executive officer is also the founder of the firm for approximately five percent of firm-years. Institutions own on average over 50 percent of outstanding shares, and industry-expert 
external auditors are present approximately 34 percent of the time. Also, the firms within my sample are large. The average market capitalization is almost five billion dollars, and there are only two firms (three firm-years) not considered accelerated or large-accelerated filers by the SEC.

Table 1 Panel E provides descriptive statistics for both the misconduct and nonmisconduct years. The composite IAF quality measure is statistically higher for the sample without management misconduct. The IAF competence, objectivity, and underlying IAF quality measures are also statistically higher for the sample without management misconduct with the exception of training (TRAINING). Overall, these univariate results are consistent with the proposition that IAF quality, competence and objectivity deter management misconduct.

The firm-years without management misconduct have a statistically higher percentage of IAF hours used as direct assistance for external auditors. Consistent with predictions, firm-years with management misconduct have a lower percentage of audit committee members with accounting expertise, are more likely to have a chief executive officer who also chairs the board of directors or a chief executive officer who is also the founder of the firm, have lower institutional ownership, have a larger market capitalization, and have a larger percentage of foreign sales. Also, the median book-tomarket ratio is smaller for firm-years with management misconduct compared to firmyears without management misconduct, which is consistent with expectations.

Table 1 Panel F presents the breakdown of management misconduct by year. In the sample, the number of firm-years with management misconduct was highest in 2001 
and 2002 and lowest in 2009. The percentage of firm-years with management misconduct declines over the sample period. The low number of observed instances of management misconduct in the later years of the sample period could be because not enough time has passed to reveal the final number of management misconduct for that year. For example, SEC investigations often span numerous years. Additional instances of management misconduct related to later sample years could be revealed in the future.

Table 2 presents Pearson correlations between variables of interest. QUALITY, COMPETENCE, and OBJECTIVITY are negatively correlated with management misconduct. This is consistent with the proposition that overall IAF quality as well as its underlying components of competence and objectivity deter management misconduct. The percentage of audit committee accounting experts and independent board members are positively correlated with the composite measure of IAF quality, and chief executive officer duality is negatively associated with the composite measure of IAF quality. These correlations are consistent with better governed firms having higher quality IAFs.

\subsection{Multivariate Levels Analysis}

Table 3, Panel A provides results of testing H1, H2, and H3. Consistent with H1, the coefficient on QUALITY is negative and significant in column one, suggesting IAF quality is negatively related to the likelihood of management misconduct. The coefficient on IAF quality is economically significant. Holding all other variables at their means, a one standard deviation increase in the IAF quality measure represents a decrease of 0.5 percentage points in the likelihood of management misconduct, a 29.7 percent decrease compared to the base rate of 1.6 percent. Table 3, Panel B presents marginal effects using 
the average of discrete or partial changes over all observations (Bartus 2005). Using this method to calculate marginal effects, a firm with IAF quality that is one standard deviation above the mean is approximately 2.3 percentage points less likely to have management misconduct as compared to the firm with average IAF quality. ${ }^{21}$ This is approximately 24 percent of the unconditional probability of management misconduct.

Consistent with $\mathrm{H} 2$, the coefficient on COMPETENCE in column two is negative and significant. This suggests IAF competence deters management misconduct. Surprisingly the coefficient on OBJECTIVITY is unrelated to the likelihood of management misconduct. Thus, the evidence does not support $\mathrm{H} 3 .{ }^{22}$ In the third column I replace QUALITY with EXPERIENCE, CERTIFICATION, TRAINING, NOT_TRAINING_GROUND, INDEPENDENT, and IAF_SIZE. In this multivariate setting, the only one of these underlying IAF quality measures that is statistically significant is CERTIFICATION. This provides further support for a negative association betwteeen IAF competence and the likelihood of management misconduct.

The control variables are generally either consistent with predictions or insignificant. The presence of a chief executive officer who is also the firm founder is positively associated with the likelihood of management misconduct, which is consistent with these individuals inappropriately influencing company operations and the board of directors. The percentage of institutional ownership is negatively associated with the

\footnotetext{
${ }^{21}$ The change in likelihood of management misconduct is calculated by multiplying the coefficient on QUALITY in Table 3, Panel B by the standard deviation of QUALITY.

${ }_{22}^{22}$ In untabulated results, I re-estimate equation (1) and include either COMPETENCE or OBJECTIVITY, but not both at the same time. In these specifications, COMPETENCE is once again significant, and OBJECTIVITY remains insignificant. This suggests that it is control variables, not COMPETENCE, that is removing the significant effect of OBJECTIVITY found in univariate results.
} 
likelihood of management misconduct. This is consistent with institutional owners improving oversight of managers or the governance process. The natural log of market capitalization and leverage are both positively associated with the likelihood of management misconduct. The only significant coefficient that is inconsistent with ex ante predictions is the positive coefficient on the book-to-market ratio. It appears that this unexpected association results from including market capitalization in the regression because the correlation between $B M$ and LMARKETCAP is -0.283 . In untabulated results, when LMARKETCAP is removed from the regression, the coefficient on $B M$ is negative and insignificant. The remaining coefficients are insignificant.

\subsection{Response by Misconduct Firms}

Table 4 provides results for equation (2). The first column presents results when the dependent variable is QUALITY. Consistent with expectations, the coefficient on MISCONDUCT_FIRM is negative and significant, indicating that IAF quality is lower for misconduct firms during misconduct years compared to control firms. Additionally, the coefficient on the interaction of MISCONDUCT_FIRM and POST_MISCONDUCT is positive and significant. This is consistent with misconduct firms improving IAF quality in response to revealed management misconduct.

Column two and three provide results when the dependent variable is COMPETENCE and OBJECTIVITY, respectively. The results for IAF competence are consistent with the results for IAF quality. That is, the coefficient on MISCONDUCT_FIRM is negative and significant, and the coefficient on the interaction of MISCONDUCT_FIRM and POST_MISCONDUCT is positive and significant. These 
results suggest that misconduct firms had lower IAF competence during misconduct years as compared to control firms, but then took steps to incrementally increase IAF competence in the post-misconduct years. Interestingly, the results for IAF objectivity do not suggest any difference in IAF objectivity between misconduct firms and control firms during the misconduct years or any incremental increase in IAF objectivity for the misconduct firms in the post misconduct years compared to the misconduct years.

The coefficients on the control variables are generally insignificant. Chief executive officer duality is negatively related to IAF quality and to IAF objectivity, but not to IAF competence. The extent to which the external audit uses the internal auditor for direct assistance is positively associated with IAF competence, but not with IAF quality or IAF objectivity. This could be because external auditors have an easier time assessing the competence of the IAF as compared to the objectivity of the IAF. LMARKETCAP and ISSUE are negatively related to IAF quality and competence, and LMARKETCAP is negatively related to IAF objectivity. CEOFOUNDER is unexpectedly positively associated with IAF objectivity. The remaining control variables are insignificant.

Overall, the univariate and multivariate levels analyses provide consistent evidence that IAF quality and IAF competence are negatively associated with the likelihood of management misconduct. Additionally, while IAF objectivity is lower in the misconduct sample, IAF objectivity is unrelated to management misconduct in multivariate levels analysis. The difference-in-differences analysis is consistent with the multivariate levels analysis in that the evidence suggests that misconduct firms respond to revealed management misconduct by improving IAF quality and competence, but not 
objectivity. Thus, IAF competence appears to be at least as important, if not more important, than IAF objectivity when it comes to deterring management misconduct. 


\section{Chapter 6: Additional Analyses}

\subsection{Accounting- and Non-Accounting-Related Management Misconduct}

Internal auditors provide assurance related to business risks, not just accountingrelated business risks. I next investigate separately the effects of IAF quality on accounting- and non-accounting-related management misconduct. Ex ante, there is no reason to suspect that IAF quality should affect one type of management misconduct more than the other unless the focus of the IAF is different. For example, one audit committee might decide to have the IAF focus more on accounting-related risks than another. Unfortunately, the survey question relating to where IAFs spend their time changed often throughout the sample period. ${ }^{23}$ The surveys did consistently ask for the percentage of time spent directly assisting the external auditors, and ASSISTS_AUDITOR is included as a control variable in the prior analyses. However, there is no clear way to estimate the time spent on accounting- versus non-accounting related activities across the time period. ${ }^{24}$ The focus of the IAF should be driven by the yearly risk assessment performed by the IAF and supported by the audit committee. If an appropriate risk assessment is performed and if the audit committee supports the risk assessment, then the IAF should be focusing on the relevant risks of the company. The subsequent analysis should be considered in light of the limitations of the data.

To test the effects of IAF quality on accounting- and non-accounting related management misconduct, I first determine whether each instance of misconduct is or is

\footnotetext{
${ }^{23}$ See Appendix B for more detail.

${ }^{24}$ There is a question in the 2001 through 2006 surveys that relates to the financial focus of the IAF. Thus, in a robustness test, I control for the financial focus of the IAF for firm-years 2000 through 2005.

Inferences remain the same in this analysis (see Section 7.7).
} 
not related to accounting. Accounting-related management misconduct, ACCOUNTING_MIS, includes (1) violation years from the Federal Securities Regulation Database where fraud or other intentional misconduct is alleged unless the violation stems from a violation of the bribery provisions of the Foreign Corrupt Practices Act of 1977 and (2) class period years for settled securities class-action lawsuits that allege violations of Generally Accepted Accounting Principles per Stanford Securities Class Action Clearinghouse. I exclude violations of the bribery provisions of the Foreign Corrupt Practices Act of 1977 from accounting-related management misconduct and instead classify them as non-accounting-related management misconduct because, after reading the individual cases, it is clear that the accounting manipulations were made in order to cover up the illegal bribery. Thus, the initial intent of management was to bribe to gain a business advantage, and the accounting manipulations were secondary. Nonaccounting related management misconduct, NONACCOUNTING_MIS, includes class period years for settled securities class-action lawsuits per Stanford Securities Class Action Clearinghouse that do not allege violations of Generally Accepted Accounting Principles and violation years for SEC and Department of Justice enforcement actions claiming violations of the bribery provisions under the Foreign Corrupt Practices Act of 1977.

Panel A of Table 5 presents the results of analyzing the effect of IAF quality on accounting-related management misconduct. The coefficient on QUALITY is negative and significant in column one, suggesting IAF quality is negatively related to the likelihood of accounting-related management misconduct. The coefficient on 
COMPETENCE in column two is negative and significant, which suggests IAF competence deters accounting-related management misconduct. Similar to the main analysis, the coefficient on OBJECTIVITY is unrelated to the likelihood of accountingrelated management misconduct. Also consistent with the main analysis, in the third column the coefficient on IAF certification is negative and statistically significant, but the coefficients on the other underlying IAF quality measures are insignificant. These results are consistent with the main analysis and suggest that IAF quality deters accountingrelated management misconduct.

Panel B of Table 5 presents the results of analyzing the effect of IAF quality on non-accounting-related management misconduct. The coefficient on QUALITY is negative and significant in column one, which is consistent with the proposition that IAF quality deters non-accounting-related management misconduct. However, the underlying IAF quality measures in columns two and three are all insignificant. While the results are weaker for non-accounting- compared to accounting-related management misconduct there is some evidence that IAF quality deters non-accounting-related management misconduct. The negative relation between IAF quality and non-accounting-related management misconduct is important because it is possible that the IAF is the main resource for audit committees to monitor management with respect to non-accounting misconduct.

\subsection{Predicting Accounting-Related Management Misconduct}

My main analysis does not control for observable indications of financial misreporting (for instance, unusual accrual activity), which would assist in predicting 
concurrent accounting-related management misconduct. I exclude indications of misreporting from my main analysis because I am primarily interested in how IAF quality deters managers from engaging in management misconduct in the first place, given other constraints on management misconduct in the firm's governance structure.

Next, I examine whether IAF quality serves as a predictor of accounting-related management misconduct. This provides insight into whether disclosures of IAF quality would be informative to investors. Interviewees in Archambeault et al. (2008) state that a report on internal audit would not only be useful to various stakeholders, but could also increase IAF accountability and incentives to perform effectively. Holt and DeZoort (2009) found that participants in their experiment were more confident in financial reporting reliability and perceived the oversight of financial reporting to be more effective when provided with an internal audit report.

Dechow et al. (2011) develop an F-score, which predicts concurrent material accounting misstatements. I utilize Model 3 from Dechow et al. (2011) to calculate an Fscore for each firm-year in the sample, excluding the finance industry. I then test whether IAF quality is negatively associated with accounting-related management misconduct after controlling for the F-score. I also examine the effect of IAF quality on accountingrelated management misconduct when controlling for the underlying variables used to compute the F-score. The F-score from Dechow et al. (2011) is computed as follows:

$$
\begin{aligned}
& \text { FSCORE }=-4.2388+1.2671 R_{S S T}+5.5275 C H \_R E C_{t}-11.1314 C H \_I N V_{t}+ \\
& 1.0695 S O F T \_A S S E T S_{t}+0.5511 C H \_C S_{t}-2.7419 C H \_R O A_{t}+0.2947 I S S U E_{t}- \\
& 0.5602 C H \_E M P_{t}-0.4097 L_{E A S E}-2.4602 R E T U R N_{t}-0.5417 R E T U R N_{t-1}
\end{aligned}
$$


See Appendix A for detailed variable definitions and Appendix D for the regression that generated the coefficients in equation (3). Following Price et al. (2011), for empirical tests I convert the estimated F-score to a probability using the following formula: $\exp (\mathrm{F}$-score $) /(1+\exp (\mathrm{F}$-score $))$.

Table 6 presents the results of regressions examining the predictive ability of IAF quality on accounting-related management misconduct. In the first column, I regress ACCOUNTING_MIS on IAF_QUAILTY and FSCORE. The coefficient on FSCORE is positive and significant, as expected. The coefficient on $I A F \_Q U A L I T Y$ is negative and significant, suggesting that IAF quality is a predictor of accounting-related management misconduct even after controlling for the F-score from Dechow et al. (2011). In column two I include the control variables from equation (1) in the regression. I exclude ISSUE because it is part of the F-score calculation. In the third column I include the underlying variables used to calculate the F-score within the regression. Finally, in column four I include control variables from equation (1) and the underlying variables used to calculate the F-score within the regression. Consistent with column one, the coefficients on $I A F \_Q U A L I T Y$ in columns two, three, and four are negative and significant. These results suggest that IAF quality is a good predictor of accounting-related management misconduct and provide empirical evidence of the claims of stakeholders in Archambeault et al. (2008) that disclosure of IAF quality could be beneficial to the market. 


\section{Chapter 7: Robustness Tests and Exploratory Analyses}

In this section I perform numerous robustness tests and exploratory analyses.

\subsection{Interaction of Competence and Objectivity}

External auditors are required to assess both IAF competence and objectivity when planning to rely on the work of the IAF (AICPA 1997; PCAOB 2010; IAASB 2012). Additionally, both international and U.S. auditing standards explicitly state that competence and objectivity are not substitutes (PCAOB 2007; IAASB 2012). That is high competence cannot overcome low objectivity and vice versa.

Next, I examine a possible interactive effect of IAF competence and objectivity on the likelihood of management misconduct. $O B J$ is an indicator variable that is set to one when OBJECTIVITY is greater than zero, and zero otherwise. COMP is an indicator variable that is set to one when COMPETENCE is greater than zero, and zero otherwise.

Table 7 presents the results. The coefficient on COMP is negative and significant, suggesting that IAF competence is negatively associated with the likelihood of management misconduct. The coefficient on $O B J$ is insignificant, which suggests there is no relation between IAF objectivity and the likelihood of management misconduct. The coefficient on the interaction of $C O M P$ and $O B J$ is also insignificant, suggesting there is no interactive effect of IAF competence and objectivity on the likelihood of management misconduct. Caution should be used when interpreting these results because it is possible that all firm-years in my sample have high enough IAF objectivity such that greater IAF competence has an increased negative effect on the likelihood of management misconduct. 


\subsection{Time-Period Analyses}

In this section, I re-estimate equation (1) for the following time periods: 2000 through 2001, 2000 through 2003, 2000 through 2005, and 2002 through 2009. I perform this analysis because (1) the rate of management misconduct and the average IAF quality are relatively stable in the early years of the sample, (2) corporate governance changes were implemented in 2002 as a result of the passage of SOX, (3) internal control testing requirements were implemented in 2004 as a result of the passage of SOX, and (4) the Global Auditing Information Network survey question relating to the use of the IAF as a management training ground is the same from 2001 through 2006 (for firm-years 2000 through 2005) and is removed from the survey after 2006.

Results are presented in Table 8. Table 8, Panel A presents results for years 2000 through 2001. Inferences are consistent with the main analysis. In column one, the coefficient on IAF_QUALITY is negative and significant, and in column two the coefficient on COMPETENCE is negative and significant, but the coefficient on OBJECTIVITY is positive and insignificant. Similar to the main analysis, these results suggest that IAF quality, and in particular competence, are negatively associated with the likelihood of management misconduct. In column three, the coefficient on CERTIFICATION is negative and significant, consistent with the main analysis. Also, the coefficient on IAF_SIZE is negative and significant, which suggests that a higher industry-adjusted IAF budget is negatively associated with the likelihood of management misconduct. The coefficient on CEOFOUNDER in each column is negative and very large in absolute value. This results from there only being two observations in years 2000 
and 2001 where CEOFOUNDER equals one, and in both of these cases there is no management misconduct.

Table 8, Panel B presents results for years 2000 through 2003, and Table 8, Panel C presents results for years 2000 through 2005. Results for these time periods are generally consistent with prior findings. Specifically, the coefficients on QUALITY, COMPETENCE, CERTIFICATION, and IAF_SIZE are negative and significant. Additionally, the coefficient on TRAINING is negative and significant for these time periods (see column three in both panels). This suggests that the amount of training the IAF completes during the year is negatively associated with the likelihood of management misconduct.

Table 8, Panel D presents results for years 2002 through 2009. Results for this time period are generally consistent with the analysis from 2000 through 2001. Specifically, the coefficients on QUALITY, COMPETENCE, and CERTIFICATION are negative and significant.

Overall, Table 8 demonstrates that the negative association between IAF quality and the likelihood of management misconduct, the negative association between IAF competence and the likelihood of management misconduct, and the insignificant association between IAF objectivity and the likelihood of management misconduct are robust to time-period analyses and potential shocks to governance created by SOX.

\subsection{External Auditor Expertise}

In the main analysis (see Table 3), the coefficient on AUDITOR_SPECIALIST is insignificant, suggesting that external auditor quality is not associated with the likelihood 
of management misconduct. Despite the vast literature examining external auditor quality and financial reporting quality, there is little literature that links external auditor quality to observable instances of management misconduct. Based on a sample from 1981 to 2001, Lennox and Pitman (2010) find that clients of Big 5 auditors have fewer instances of SEC Accounting and Auditing Enforcement Releases compared to clients of non-Big 5 auditors. Their results are consistent with the proposition that Big $\mathrm{N}$ auditors provide better audit quality and that they can deter accounting-related management misconduct. However, with respect to deterring accounting-related management misconduct, the literature has not examined differences within the Big N (e.g., industry expertise) or the post-SOX time period. It is possible that after the governance changes of SOX, external auditor quality does not significantly affect the likelihood of accounting-related management misconduct either because of improved overall corporate governance or because external auditor quality has improved and become more homogenous.

It is difficult to examine the effects of Big 4 auditors on management misconduct in my sample because only 67 firm-years in my sample do not have a Big 4 auditor. ${ }^{25}$ Thus, I focus on the industry expertise of the external auditor, which allows for greater variation in the auditor expertise variable. Francis et al. (2005) find that industry expertise is only priced when the auditor is both a national and city industry expert. To supplement the main analysis, I re-estimate equation (1) and replace AUDITOR_SPECIALIST with CITY_SPECIALIST and then with JOINT_SPECIALIST. CITY_SPECIALIST is set to one for year $t$ when the firm is audited by the external

\footnotetext{
${ }^{25}$ For equation (1), if I include an indicator set to one when the external auditor is a Big 4 auditor, it is insignificant. However, because of the low variation in the Big 4 indicator, there is little power for the test.
} 
auditor with the highest industry market share based upon the city where the firm's corporate headquarters is located. JOINT_SPECIALIST is set to one when the external auditor is both a national and a city industry expert (i.e., when both AUDITOR_SPECIALIST and CITY_SPECIALIST are equal to one) for year $t$.

Table 9 presents the results. The coefficient in column one on CITY_SPECIALIST and the coefficient in column two on JOINT_SPECIALIST are insignificant. These results suggest that external auditor quality, for my sample consisting of large firms, does not affect the likelihood of management misconduct. In untabulated results, I also estimate the effects of AUDITOR_SPECIALIST, CITY_SPECIALIST, and JOINT_SPECIALIST on the likelihood of accounting-related management misconduct, and results are consistent. Specifically, the coefficients on auditor industry expertise are insignificant under each specification.

7.4 Controlling for Material Weaknesses in Internal Control over Financial Reporting The IAF is part of the internal control structure of the firm. A firm that is committed to strong internal controls should have both a strong IAF and also strong internal controls over financial reporting. It is possible that a strong IAF is just one of many types of internal controls that would affect the likelihood of management misconduct. Next, I test whether IAF quality is negatively associated with the likelihood of management misconduct after controlling for material weaknesses in internal control over financial reporting. To perform this analysis I gather material weaknesses in internal control over financial reporting from Audit Analytics based upon SOX Section 302 and 404 disclosures. These disclosures are available starting in 2002. $M W$ is an indicator 
variable that is set to one for year $t$ when there is a material weakness in internal control over financial reporting during that year (e.g., if the quarterly SOX Section 302 reports or the annual SOX Section 404 reports for year $t$ indicate that a material weakness was present for year $t$, then $M W$ is set to one for year $t$ ).

Results are presented in Table 10. The coefficient on $M W$ in each of the three columns is positive and significant indicating that material weaknesses in internal controls over financial reporting are reported for years when management is committing misconduct. The results for the remaining variables, including for the variables relating to IAF quality, are the same as in the main analysis. The coefficients on QUALITY in the first column, COMPETENCE in the second column, and CERTIFICATION in the third column remain negative and significant after controlling for internal control quality. This is consistent with the proposition that, on average, IAF quality and competence deter management misconduct holding internal control quality constant.

\subsection{Response by Misconduct Firms - Supplemental Analysis}

In Chapter 5.3, results suggest that misconduct firms respond to revealed management misconduct by increasing IAF quality, and specifically IAF competence, as compared to a control sample. In this section, I explore whether misconduct firms respond to revealed misconduct by improving the underlying dimensions of IAF quality. Specifically, I re-estimate equation (2), but replace the dependent variable with EXPERIENCE, CERTIFICATION, TRAINING, NOT_TRAINING_GROUND, INDEPENDENT, and IAF_SIZE. Results are presented in Table 11. 
Table 11 presents results for equation (2) but with the dependent variable set to EXPERIENCE in column one, CERTIFICATION in column two, TRAINING in column three, NOT_TRAINING_GROUND in column four, INDEPENDENT in column five, and $I A F \_S I Z E$ in column six. Control variables are included in the regressions, but are not presented in the table for parsimony. The coefficient on MISCONDUCT_FIRM is negative and significant when the dependent variable is either EXPERIENCE or CERTIFICATION, but insignificant otherwise. The coefficient on the interaction of MISCONDUCT_FIRM and POST_MISCONDUCT is positive and significant when the dependent variable is either EXPERIENCE or CERTIFICATION, but insignificant otherwise. This suggests that firms that experienced management misconduct had IAFs with less experience and certification levels during misconduct years, but responded to the revealed misconduct by increasing IAF experience and certification. Thus, the evidence suggests that in response to management misconduct, firms seek to improve IAF competence by hiring internal auditors who are more experienced and who have demonstrated their competence by obtaining the CIA, CPA, or CFE certification.

\subsection{Controlling for the Extent of IAF Outsourcing}

When IAFs lack skills necessary to complete an audit, it is common for the firm to outsource the audit to a service provider with the requisite skills. In some cases firms have chosen to fully outsource their IAFs. It is unclear how IAF outsourcing may affect IAF quality and management misconduct. Next, I test whether IAF quality is negatively associated with the likelihood of management misconduct after controlling for the extent of IAF outsourcing. OUTSOURCED is a composite measure of the extent to which the 
IAF is outsourced. The variable can range from zero to four. It is set to zero when there are no IAF audits that are outsourced or co-sourced; it is set to one when there is more than zero and up to 25 percent outsourcing or co-sourcing of the IAF; it is set to two when there is more than 25 percent and up to 50 percent outsourcing or co-sourcing of the IAF; it is set to three when there is more than 50 percent and less than 100 percent outsourcing or co-sourcing of the IAF; it is set to four when there is 100 percent outsourcing or co-sourcing of the IAF.

Results are presented in Table 12. The coefficient on OUTSOURCED in each of the three columns is insignificant indicating that IAF outsourcing is unrelated to the likelihood of management misconduct. The results for the remaining variables, including for the variables relating to IAF quality, are the same as in the main analysis. The coefficients on QUALITY in the first column, COMPETENCE in the second column, and CERTIFICATION in the third column remain negative and significant after controlling for internal control quality. This is consistent with the proposition that, on average, IAF quality and competence deter management misconduct holding IAF outsourcing constant. 7.7 Controlling for the Financial Focus of the IAF

The focus of the IAF could have an effect on the deterrence of specific types of management misconduct. For example, an IAF that focuses more time on financial accounting related audits could have more of a deterrent effect on accounting-related management misconduct versus non-accounting-related management misconduct. Next, I test whether IAF quality is negatively associated with the likelihood of accounting- 
related management misconduct and non-accounting-related management misconduct after controlling for the financial focus of the IAF.

One challenge with this analysis is that questions pertaining to the focus of the IAF change throughout the time period. However, there is a set of questions relating to the financial focus of the IAF that is consistently asked within the 2001 through 2006 surveys. Thus, this analysis includes firm-years from 2000 through 2005 . FINANCIAL_FOCUS is an average of five survey questions that rate the frequency with which the IAF audits financial accounting activities (Pizzini et al. 2012). The audit activities are (1) the adequacy of internal accounting controls, (2) the accuracy, reliability, and completeness of financial records, (3) the impact of changes in accounting rules or regulations, (4) interim financial results that are reported externally, and (5) Generally Accepted Accounting Principles. The responses for each of the activities are never $(=0)$, occasionally $(=1)$, and regularly $(=2)$.

Results are presented in Table 13. Panel A of Table 13 presents the results when the dependent variable is accounting-related management misconduct (i.e., ACCOUNTING_MIS). The coefficient on FINANCIAL_FOCUS in each of the three columns is insignificant suggesting that the financial focus of the IAF is insignificantly related to the likelihood of accounting-related management misconduct. The coefficient on COMPETENCE in the second column is negative and significant, and the coefficients on CERTIFICATION and IAF_SIZE in the third column are both negative and significant. These results are consistent with IAF competence, certification, and size deterring 
accounting-related management misconduct after controlling for the financial focus of the IAF.

Panel B of Table 13 presents the results when the dependent variable is nonaccounting-related management misconduct (i.e., NONACCOUNTING_MIS). The coefficient on FINANCIAL_FOCUS in each of the three columns is insignificant suggesting that the financial focus of the IAF is insignificantly related to the likelihood of non-accounting-related management misconduct. The coefficients on QUALITY in the first column and CERTIFICATION in the third column are both negative and significant. These results are consistent with IAF quality and certification deterring non-accountingrelated management misconduct after controlling for the financial focus of the IAF.

Overall, the results in this section support the main analysis. After controlling for the financial focus of the IAF, there is still a negative relation between measures of IAF quality and the likelihood of management misconduct, whether accounting-related or non-accounting-related. However, this analysis is limited in that it is performed for years 2000 through 2005 because survey data relating to the financial focus of the IAF are not available for years 2006 through 2009. Therefore, results should be considered in light of this limitation.

\subsection{Instrumental Variables Approach}

Firms committed to strong governance may choose high-quality IAFs and also choose managers who are less likely to engage in management misconduct. Thus, there could be a joint determination of high IAF quality and low likelihood of management misconduct. Accordingly, in my main analysis I include control variables which proxy 
for a firm's commitment to strong governance. Specifically, I control for audit committee accounting expertise, director independence, institutional ownership, chief executive officer duality, the existence of a chief executive officer who is also the firm founder, and external auditor industry expertise. Also, I provide evidence that misconduct firms improve IAF quality in response to revealed management misconduct. However, it is still possible that correlated omitted variables affect my results.

An instrumental variables method is another approach to attempt to further mitigate this endogeneity concern. However, a major challenge with an instrumental variables approach is selecting an instrument that is correlated with the potentially endogenous variable (i.e., QUALITY) and also uncorrelated with the error term in the structural equation (Larcker and Rusticus 2010). In this section I explore two possible instruments: industry-average IAF quality and listing on the New York Stock Exchange.

The industry-average IAF quality should be a strong predictor of firm-specific IAF quality. For example, firms respond to the Global Auditing Information Network survey in order to benchmark their IAF function against industry practices. However, industry-average IAF quality combines both the endogenous and exogenous portions of firm-specific IAF quality, and thus, industry averages are generally not very good instruments (Larcker and Rusticus 2010). As an instrument for firm i's IAF quality, I use the average IAF quality for the other firms in the same industry as firm $i$ (Lev and Sougiannis 1996). In untabulated results industry-average IAF quality is positively associated with firm-specific IAF quality in the first stage, but in the second stage the coefficient on the predicted value of IAF quality is insignificant. 
Listing on the New York Stock Exchange could be a predictor of firm-specific IAF quality because the New York Stock Exchange requires listed firms to have an IAF. Therefore, as compared to NASDAQ firms, New York Stock Exchange firms might invest in IAFs because they have to have them. However, because the firms in my sample choose to participate in benchmarking their IAFs, it is likely that all sample firms are committed to investing in their IAFs. Therefore, there is likely no difference in IAF quality between sample firms that list on the New York Stock Exchange and those that list on NASDAQ. In untabulated results, listing on the New York Stock Exchange is unassociated with firm-specific IAF quality in the first stage. This suggests that listing on the New York Stock Exchange is not a good instrument for IAF quality.

An instrumental variables method requires justification of the instruments (Larcker and Rusticus 2010). There are arguments for why the industry-average of IAF quality and listing on the New York Stock Exchange could be valid instruments for firmspecific IAF quality. However, there are also strong reasons to think otherwise. While I attempt to control for firm governance and show that misconduct firms improve IAF quality post misconduct, my results should be considered in light of being unable to demonstrate results via an instrumental variables approach. 


\section{Chapter 8: Conclusion}

Standard-setters claim IAF quality deters management misconduct. In response to management misconduct in the early 2000s, regulators passed regulation to enforce board, audit committee, and external auditor quality, but did not pass regulation that enforces IAF quality or requires IAF-related disclosures. I find that a composite measure of IAF quality, as well as IAF competence, is negatively associated with the likelihood of management misconduct, controlling for other determinants of management misconduct including board, audit committee, and external auditor quality. This result is economically significant. Holding all other variables at their means, a one standard deviation increase in the IAF quality measure represents a 0.5 percentage point decrease in the likelihood of management misconduct, a 29.7 percent decrease compared to the base rate of 1.6 percent. Additionally, I find evidence consistent with firms improving IAF quality, by increasing IAF competence, after management misconduct is revealed. Specifically, misconduct firms appear to hire internal auditors who have more experience and more certifications after revealed management misconduct as compared to control firms. Overall, this evidence is consistent with IAFs serving as an important deterrent to management misconduct. Accordingly, regulators and audit committees should consider ways to improve IAF quality and more specifically, IAF competence. For example, firms listed on the New York Stock Exchange are required to have an IAF that meets privately with the audit committee, and it appears that firms listed on NASDAQ will soon have similar requirements. Access to the audit committee could improve IAF objectivity, but listing requirements do not directly address IAF competence. My study suggests that 
these stock exchanges should also consider whether audit committees are ensuring a proper level of IAF competence.

I also find that IAF quality is negatively associated with accounting-related management misconduct even after controlling for other observable predictors of misconduct (Dechow et al. 2011). This suggests that IAF quality is a good predictor of accounting-related management misconduct and supports survey and experimental evidence that reports that disclosure of information related to the IAF would increase stakeholder confidence in governance quality and potentially affect investment decisions (Archambeault et al. 2008; Holt and DeZoort 2009). Accordingly, investors could benefit from disclosures pertaining to IAF quality.

This study contributes to the IAF literature and the management misconduct literature because it is the first study to link IAF quality to observable instances of management misconduct. I also add to the literature by demonstrating that under the current regulatory regime, IAF competence is at least as important as IAF objectivity as it relates to deterring management misconduct. Finally, I add to the governance literature that investigates governance changes that occur after management misconduct is revealed. My findings are especially important to practice given anecdotal evidence that IAF quality is low for some firms. Additionally, results support the Institute of Internal Auditors' standards, which call for IAFs to be competent and objective.

There are several limitations to this study. First, it is possible that IAF quality and the likelihood of management misconduct are jointly determined. Because of this, I included control variables in the levels analysis that capture corporate governance 
quality. Additionally, the changes analysis helps to allay some endogeneity concerns as the evidence is consistent with firms viewing improving IAF quality as an important response to revealed management misconduct. Second, the no result between IAF objectivity and the likelihood of management misconduct should be interpreted with caution. It is possible that all firms in the sample have sufficiently high levels of IAF objectivity and / or that there is not enough variation on the IAF objectivity measures within the sample to demonstrate a significant association between IAF objectivity and the likelihood of management misconduct. My results should not be interpreted as IAF objectivity does not affect the likelihood of management misconduct. Future studies should consider the effects of IAF objectivity on the likelihood of management misconduct as better measures of IAF objectivity become available. Third, it is possible that survey respondents introduced errors in the data. These errors should introduce noise into the analyses rather than biases in one direction or the other, but the reader should consider the potential for errors in the survey responses. 


\section{Tables}

\section{Table 1, Panel A: Response Frequency of Firms}

\begin{tabular}{|ccc|}
\hline \multicolumn{3}{|c|}{ Total firm-years = 1,398 } \\
\hline $\begin{array}{c}\text { Number of firm-years } \\
\text { for each firm }\end{array}$ & $\begin{array}{c}\text { Number of } \\
\text { firms }\end{array}$ & $\begin{array}{c}\text { Percent of } \\
\text { firms }\end{array}$ \\
\hline & 322 & $52 \%$ \\
1 & 114 & $18 \%$ \\
2 & 66 & $11 \%$ \\
3 & 45 & $7 \%$ \\
4 & 19 & $3 \%$ \\
5 & 18 & $3 \%$ \\
6 & 13 & $2 \%$ \\
7 & 10 & $2 \%$ \\
8 & 4 & $1 \%$ \\
9 & 6 & $1 \%$ \\
10 & 617 & $100 \%$ \\
\hline Total & & \\
\hline
\end{tabular}

This panel provides a count and related percentage of how many times sample firms responded to the Global Auditing Information Network survey from 2000 through 2009. 
Table 1, Panel B: Firm-Years by Industry

\begin{tabular}{|lcccc|}
\hline Industry & Firm-Years & $\begin{array}{c}\text { Firm-Years With } \\
\text { Misconduct }\end{array}$ & $\begin{array}{c}\text { Percent with } \\
\text { Misconduct }\end{array}$ & $\begin{array}{c}\text { Average } \\
\text { QUALITY }\end{array}$ \\
\hline Consumer Non-Durables & & & & \\
Consumer Durables & 90 & 0 & $0 \%$ & 2.88 \\
Manufacturing & 34 & 1 & $3 \%$ & 2.82 \\
Oil, Gas, and Coal Extraction Products & 132 & 2 & $2 \%$ & 2.83 \\
Chemicals and Allied Products & 48 & 5 & $10 \%$ & 3.15 \\
Computer, Software, and Electronic Equipment & 60 & 2 & $3 \%$ & 2.88 \\
Telephone and Television Transmission & 191 & 47 & $25 \%$ & 2.86 \\
Utilities & 60 & 11 & $18 \%$ & 3.10 \\
Wholesale, Retail, and Some Services & 243 & 8 & $3 \%$ & 4.22 \\
Healthcare, Medical Equipment, and Drugs & 104 & 5 & $5 \%$ & 3.02 \\
Finance & 63 & 17 & $27 \%$ & 3.11 \\
Other & 245 & 33 & $13 \%$ & 3.53 \\
& 128 & 7 & $5 \%$ & 3.19 \\
\hline
\end{tabular}

This table provides the number of firm-years and misconduct years in the sample by the Fama-French 12 industry classification. Misconduct includes (1) violation years from the Federal Securities Regulation Database where fraud or other intentional misconduct is alleged, (2) class period years for settled securities class-action lawsuits per Stanford Securities Class Action Clearinghouse, and (3) violation years for SEC and Department of Justice Enforcement Actions claiming violation of the bribery provisions of the Foreign Corrupt Practices Act of 1977. QUALITY is a composite measure of IAF quality that ranges from zero to six with zero representing the lowest quality and six representing the highest quality. 
Table 1, Panel C: Comparison of Governance Outcomes

\begin{tabular}{|lccc|}
\hline \multicolumn{1}{|c}{ Outcome Variable } & $\begin{array}{c}\text { Average for Sample } \\
\text { Firms }\end{array}$ & $\begin{array}{c}\text { Average for Matched } \\
\text { Firms }\end{array}$ & Difference (t-stat) \\
\hline & & & $-0.002(-0.66)$ \\
Signed Discretionary Accruals & 0.018 & 0.020 & $-0.009(-2.35)$ \\
Income-Increasing Discretionary Accruals & 0.063 & 0.072 & $0.004(1.10)$ \\
Income-Decreasing Discretionary Accruals & -0.051 & -0.055 & $0.032(3.10)$ \\
Material Weaknesses in Internal Control & 0.084 & 0.052 & $0.012(2.17)$ \\
Accounting Management Misconduct & 0.029 & 0.017 & \\
\hline
\end{tabular}

This table presents comparative statistics between selected governance outcome variables for the sample that responded to the Global Auditing Information Network survey and a matched sample of firms that did not respond to the Global Auditing Information Network survey. Sample firms are matched based upon year, industry, and closest market capitalization. There are a different set of firms for each governance outcome comparison based upon available data. For example, banks are removed for the discretionary accrual calculations. Discretionary accruals are the error term from the following calculation estimated by year and two-digit Standard Industrial Classification code: TOTAL_ACCRUALS $S_{i t}=\beta_{0}+\beta_{1} *\left(1 / A S S E T S_{i t-1}\right)+\beta_{2} *\left(\Delta R E V_{i t}-\triangle A R_{i t}\right)+\beta_{3} * P P E_{i t}+\varepsilon$. TOTAL_ACCRUALS $S_{i t}$ is calculated as income before extraordinary items divided by ASSETS $_{i t-1}$ minus net cash flow from operating activities divided by ASSETS $_{i t-1}$. ASSETS ${ }_{l}$ is total assets for firm $i$ in year $t-1 . \triangle R E V_{i t}$ is the change in revenue for firm $i$ in year $t$ scaled by $A S S E T S_{i t-1} . \triangle A R_{i t}$ is the change in receivables for firm $i$ in year $t$ scaled by

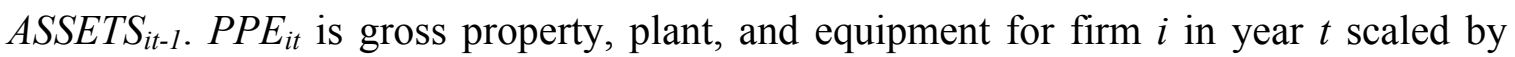
ASSETS $_{i t-1}$. Material weaknesses in internal control are gathered from SOX Section 302 and 404 disclosures within Audit Analytics. Firm-years are identified as having a material weakness if one or more material weaknesses in internal control over financial reporting are disclosed for that firm-year. Accounting management misconduct are violation years from the Federal Securities Regulation Database where fraud is alleged. 
Table 1, Panel D: Sample Descriptive Statistics

\begin{tabular}{|c|c|c|c|c|c|}
\hline \multicolumn{6}{|c|}{$\mathrm{n}=\mathbf{1 , 3 9 8}$} \\
\hline & Mean & Std Dev & 25th Pctl & Median & 75th Pctl \\
\hline \multicolumn{6}{|l|}{ Management Misconduct } \\
\hline MISCONDUCT & 0.099 & 0.298 & 0.000 & 0.000 & 0.000 \\
\hline \multicolumn{6}{|l|}{ IAF Quality } \\
\hline QUALITY & 3.286 & 1.292 & 2.000 & 3.000 & 4.000 \\
\hline COMPETENCE & 0.000 & 1.000 & -0.698 & -0.087 & 0.605 \\
\hline OBJECTIVITY & 0.000 & 1.000 & -0.486 & 0.099 & 0.564 \\
\hline EXPERIENCE & 6.358 & 3.676 & 3.852 & 6.000 & 8.275 \\
\hline CERTIFICATION & 0.613 & 0.313 & 0.400 & 0.571 & 0.769 \\
\hline TRAINING & 52.273 & 27.025 & 40.000 & 46.000 & 70.000 \\
\hline NOT_TRAINING_GROUND & 0.667 & 0.472 & 0.000 & 1.000 & 1.000 \\
\hline INDEPENDENT & 0.873 & 0.333 & 1.000 & 1.000 & 1.000 \\
\hline$I A F \_S I Z E$ & 0.000 & 1.393 & -0.579 & -0.303 & 0.213 \\
\hline \multicolumn{6}{|l|}{ Control Variables } \\
\hline ASSISTS_AUDITOR & 0.029 & 0.051 & 0.000 & 0.010 & 0.050 \\
\hline$A C \_A C C O U N T I N G \_E X P$ & 0.307 & 0.230 & 0.167 & 0.250 & 0.500 \\
\hline$B R D \_P C T \_I N D$ & 0.667 & 0.105 & 0.615 & 0.667 & 0.706 \\
\hline CEOISCHAIR & 0.657 & 0.465 & 0.000 & 1.000 & 1.000 \\
\hline CEOFOUNDER & 0.046 & 0.211 & 0.000 & 0.000 & 0.000 \\
\hline INSTITUTIONAL_OWN & 0.525 & 0.335 & 0.280 & 0.600 & 0.792 \\
\hline AUDITOR_SPECIALIST & 0.338 & 0.473 & 0.000 & 0.000 & 1.000 \\
\hline LMARKETCAP & 22.307 & 1.668 & 21.130 & 22.270 & 23.414 \\
\hline$B M$ & 0.545 & 0.617 & 0.293 & 0.471 & 0.681 \\
\hline LEVERAGE & 0.262 & 0.173 & 0.132 & 0.256 & 0.364 \\
\hline PCTFORSALES & 0.197 & 0.297 & 0.000 & 0.010 & 0.351 \\
\hline ISSUE & 0.278 & 0.448 & 0.000 & 0.000 & 1.000 \\
\hline
\end{tabular}

This panel provides descriptive statistics for my sample. Variable definitions are provided in Appendix A. 
Table 1, Panel E: Sample Descriptive Statistics by Misconduct

\begin{tabular}{|c|c|c|c|c|c|c|c|c|}
\hline \multirow[b]{2}{*}{ Variables } & \multicolumn{3}{|c|}{ MISCONDUCT = $1(\mathrm{n}=138)$} & \multicolumn{3}{|c|}{ MISCONDUCT $=0(\mathrm{n}=1,260)$} & \multicolumn{2}{|c|}{ Differences } \\
\hline & Mean & Std Dev & Median & Mean & Std Dev & Median & Mean & Median \\
\hline IAF Quality & & & & & & & & \\
\hline QUALITY & 2.543 & 1.160 & 2.500 & 3.367 & 1.281 & 3.000 & $-0.824 * * *$ & $-0.500 * * *$ \\
\hline COMPETENCE & -0.479 & 0.859 & -0.561 & 0.052 & 1.001 & -0.030 & $-0.531 * * *$ & $-0.531 * * *$ \\
\hline OBJECTIVITY & -0.250 & 0.956 & -0.121 & 0.027 & 1.001 & 0.125 & $-0.277 * * *$ & $-0.246 * * *$ \\
\hline EXPERIENCE & 5.060 & 3.233 & 4.158 & 6.500 & 3.695 & 6.000 & $-1.439 * * *$ & $-1.842 * * *$ \\
\hline CERTIFICATION & 0.492 & 0.262 & 0.468 & 0.626 & 0.316 & 0.588 & $-0.134 * * *$ & $-0.121 * * *$ \\
\hline TRAINING & 54.116 & 28.149 & 50.000 & 52.071 & 26.903 & 46.000 & 2.045 & 4.000 \\
\hline NOT_TRAINING_GROUND & 0.551 & 0.499 & 1.000 & 0.679 & 0.467 & 1.000 & $-0.129 * * *$ & $0.000 * * *$ \\
\hline INDEPENDENT & 0.812 & 0.392 & 1.000 & 0.879 & 0.326 & 1.000 & $-0.068 * *$ & $0.000 * *$ \\
\hline$I A F \_S I Z E$ & -0.415 & 0.569 & -0.592 & 0.046 & 1.448 & -0.267 & $-0.461 * * *$ & $-0.324 * * *$ \\
\hline Control Variables & & & & & & & & \\
\hline ASSISTS_AUDITOR & 0.018 & 0.031 & 0.000 & 0.031 & 0.053 & 0.010 & $-0.013 * * *$ & $-0.010 * * *$ \\
\hline$A C \_A C C O U N T I N G \_E X P$ & 0.251 & 0.214 & 0.250 & 0.313 & 0.231 & 0.286 & $-0.062 * * *$ & $-0.036 * * *$ \\
\hline$B R \bar{D} \_P C T \_I N D$ & 0.657 & 0.091 & 0.667 & 0.668 & 0.106 & 0.667 & -0.011 & 0.000 \\
\hline CEOISCHAIR & 0.742 & 0.421 & 1.000 & 0.647 & 0.469 & 1.000 & $0.094 * *$ & $0.000 * *$ \\
\hline CEOFOUNDER & 0.109 & 0.312 & 0.000 & 0.040 & 0.195 & 0.000 & $0.069 * * *$ & $0.000 * * *$ \\
\hline INSTITUTIONAL_OWN & 0.383 & 0.331 & 0.455 & 0.540 & 0.332 & 0.619 & $-0.157 * * *$ & $-0.164 * * *$ \\
\hline AUDITOR_SPECIALIST & 0.355 & 0.480 & 0.000 & 0.336 & 0.472 & 0.000 & 0.019 & 0.000 \\
\hline LMARKETCAP & 23.692 & 1.727 & 23.956 & 22.155 & 1.591 & 22.162 & $1.537 * * *$ & $1.794 * * *$ \\
\hline$B M$ & 0.529 & 1.078 & 0.375 & 0.547 & 0.544 & 0.477 & -0.018 & $-0.102 * * *$ \\
\hline LEVERAGE & 0.261 & 0.195 & 0.231 & 0.262 & 0.170 & 0.259 & -0.001 & -0.028 \\
\hline PCTFORSALES & 0.317 & 0.524 & 0.253 & 0.184 & 0.257 & 0.000 & $0.132 * * *$ & $0.253 * * *$ \\
\hline ISSUE & 0.297 & 0.459 & 0.000 & 0.276 & 0.447 & 0.000 & 0.021 & 0.000 \\
\hline
\end{tabular}


The misconduct sample includes (1) violation years from the Federal Securities Regulation Database where fraud or other intentional misconduct is alleged, (2) class period years for settled securities class-action lawsuits per Stanford Securities Class Action Clearinghouse, (3) and violation years for SEC and Department of Justice Enforcement Actions claiming violations of the bribery provisions of the Foreign Corrupt Practices Act of 1977. I construct IAF quality measures using the Institute of Internal Auditors' Global Auditing Information Network database from 2000 through 2009. *,**, and *** represent two-tailed statistical significance at the 10\%, 5\%, and 1\% levels, respectively. Variable definitions are provided in Appendix A. 
Table 1, Panel F: Misconduct by Year, 2000 - 2009

\begin{tabular}{|cccc|}
\hline Year & MISCONDUCT & Total \# of Observations & \% with MISCONDUCT \\
\hline & & & \\
2000 & 17 & 75 & $23 \%$ \\
2001 & 22 & 101 & $22 \%$ \\
2002 & 21 & 101 & $21 \%$ \\
2004 & 14 & 87 & $16 \%$ \\
2005 & 12 & 133 & $9 \%$ \\
2006 & 17 & 201 & $8 \%$ \\
2007 & 15 & 208 & $7 \%$ \\
2008 & 12 & 186 & $6 \%$ \\
2009 & 6 & 163 & $4 \%$ \\
Total & 2 & 143 & $1 \%$ \\
& 138 & 1,398 & $10 \%$ \\
\hline \hline
\end{tabular}

This panel includes the number of misconduct years obtained from the Federal Securities Regulation Database, Stanford Securities Class Action Clearinghouse, SEC, and Department of Justice. Variable definitions are provided in Appendix A. 
Table 2: Pearson Correlations

\begin{tabular}{|c|c|c|c|c|c|c|c|c|c|c|c|c|c|c|c|c|c|c|c|c|c|}
\hline Variables & 1 & 2 & 3 & 4 & 5 & 6 & 7 & 8 & 9 & 10 & 11 & 12 & 13 & 14 & 15 & 16 & 17 & 18 & 19 & 20 & 21 \\
\hline $1 A L L$ & & & & & & & & & & & & & & & & & & & & & \\
\hline 2 QUALITY & -0.190 & & & & & & & & & & & & & & & & & & & & \\
\hline 3 COMPETENCE & -0.159 & 0.711 & & & & & & & & & & & & & & & & & & & \\
\hline 4 OBJECTIVITY & -0.083 & 0.151 & 0.000 & & & & & & & & & & & & & & & & & & \\
\hline 5 EXPERIENCE & -0.117 & 0.521 & 0.808 & 0.004 & & & & & & & & & & & & & & & & & \\
\hline 6 CERTIFICATION & -0.128 & 0.428 & 0.652 & -0.160 & 0.288 & & & & & & & & & & & & & & & & \\
\hline 7 TRAINING & 0.023 & 0.263 & 0.046 & -0.565 & -0.005 & -0.002 & & & & & & & & & & & & & & & \\
\hline 8 NOT_TRAINING_GROUND & -0.081 & 0.550 & 0.586 & 0.244 & 0.289 & 0.078 & -0.014 & & & & & & & & & & & & & & \\
\hline $9 \quad I N D E P E N D E N T$ & -0.061 & 0.309 & -0.066 & 0.636 & -0.016 & -0.029 & -0.046 & 0.076 & & & & & & & & & & & & & \\
\hline $10 I A F_{-} S I Z E$ & -0.099 & 0.204 & 0.190 & 0.589 & 0.090 & 0.049 & -0.088 & 0.074 & 0.075 & & & & & & & & & & & & \\
\hline 11 ASSISTS_AUDITOR & -0.075 & 0.060 & 0.035 & 0.044 & 0.042 & -0.021 & 0.012 & 0.063 & 0.057 & 0.009 & & & & & & & & & & & \\
\hline 12 AC_ACCOUNTING_EXP & -0.081 & 0.059 & -0.002 & 0.125 & -0.043 & 0.006 & -0.059 & 0.061 & 0.093 & 0.064 & -0.005 & & & & & & & & & & \\
\hline $13 B R D \_P C T \_I N D$ & -0.032 & 0.064 & 0.025 & 0.049 & 0.045 & -0.073 & 0.054 & 0.074 & 0.049 & 0.049 & -0.020 & 0.065 & & & & & & & & & \\
\hline 14 CEOISCHAIR & 0.061 & -0.070 & -0.068 & -0.153 & -0.013 & -0.074 & 0.072 & -0.071 & -0.105 & -0.119 & -0.077 & -0.161 & -0.066 & & & & & & & & \\
\hline 15 CEOFOUNDER & 0.098 & 0.014 & -0.020 & 0.068 & -0.043 & -0.004 & -0.067 & 0.034 & 0.044 & 0.006 & -0.039 & 0.077 & -0.072 & 0.079 & & & & & & & \\
\hline 16 INSTITUTIONAL_OWN & -0.140 & 0.035 & 0.039 & 0.083 & 0.008 & -0.007 & 0.028 & 0.099 & 0.098 & 0.046 & 0.114 & 0.035 & -0.042 & -0.017 & -0.057 & & & & & & \\
\hline 17 AUDITOR_SPECIALIST & 0.012 & -0.009 & -0.050 & -0.074 & -0.043 & -0.026 & 0.082 & -0.057 & -0.045 & -0.009 & -0.084 & -0.061 & 0.017 & 0.068 & 0.000 & 0.022 & & & & & \\
\hline 18 LMARKETCAP & 0.275 & -0.251 & -0.263 & -0.315 & -0.181 & -0.179 & 0.230 & -0.182 & -0.091 & -0.310 & -0.181 & -0.108 & -0.004 & 0.149 & -0.013 & -0.020 & 0.191 & & & & \\
\hline $19 B M$ & -0.009 & 0.095 & 0.145 & 0.089 & 0.130 & 0.065 & -0.031 & 0.105 & 0.051 & 0.084 & 0.097 & -0.004 & -0.014 & -0.006 & -0.044 & -0.022 & -0.001 & -0.283 & & & \\
\hline 20 LEVERAGE & -0.001 & 0.058 & 0.060 & -0.096 & 0.051 & 0.029 & 0.083 & 0.027 & -0.069 & -0.029 & -0.037 & 0.041 & 0.107 & 0.040 & -0.080 & -0.059 & 0.042 & -0.007 & -0.070 & & \\
\hline 21 PCTFORSALES & 0.133 & -0.212 & -0.198 & -0.022 & -0.198 & -0.082 & -0.023 & -0.136 & -0.050 & -0.005 & -0.071 & 0.067 & -0.008 & -0.023 & 0.051 & -0.040 & 0.081 & 0.186 & 0.140 & -0.170 & \\
\hline 22 ISSUE & 0.014 & -0.002 & 0.017 & 0.045 & -0.040 & 0.073 & -0.078 & 0.012 & -0.012 & 0.043 & 0.010 & 0.079 & -0.031 & -0.065 & 0.060 & -0.053 & -0.038 & -0.154 & 0.027 & 0.372 & -0.049 \\
\hline
\end{tabular}

Variable definitions are provided in Appendix A. Bolded coefficients are significant at the 10 percent level. 
Table 3, Panel A: Effect of IAF Quality on Management Misconduct

\begin{tabular}{|c|c|c|c|c|}
\hline \multicolumn{5}{|c|}{ Prob $($ MISCONDUCT $=1)=\mathrm{F}\left(\beta_{0}+\beta_{1} Q U A L I T Y+\right.$ Controls $)$} \\
\hline Independent Variables & Predicted Sign & $(1)$ & $(2)$ & (3) \\
\hline QUALITY & - & $\begin{array}{l}-0.2762 * * \\
(0.121)\end{array}$ & & \\
\hline COMPETENCE & - & & $\begin{array}{l}-0.3163 * * \\
(0.163)\end{array}$ & \\
\hline OBJECTIVITY & - & & $\begin{array}{l}0.1191 \\
(0.122)\end{array}$ & \\
\hline EXPERIENCE & - & & & $\begin{array}{r}-0.0451 \\
(0.047)\end{array}$ \\
\hline CERTIFICATION & - & & & $\begin{array}{c}-0.9760 * \\
(0.606)\end{array}$ \\
\hline TRAINING & - & & & $\begin{array}{r}-0.0038 \\
(0.004)\end{array}$ \\
\hline NOT_TRAINING_GROUND & - & & & $\begin{array}{l}0.0510 \\
(0.321)\end{array}$ \\
\hline INDEPENDENT & - & & & $\begin{array}{l}0.1782 \\
(0.326)\end{array}$ \\
\hline$I A F \_S I Z E$ & - & & & $\begin{array}{l}-0.2914 \\
(0.304)\end{array}$ \\
\hline ASSISTS_AUDITOR & $?$ & $\begin{array}{r}-2.5833 \\
(3.284)\end{array}$ & $\begin{array}{r}-2.4241 \\
(3.405)\end{array}$ & $\begin{array}{l}-2.9678 \\
(3.453)\end{array}$ \\
\hline$A C \_A C C O U N T I N G \_E X P$ & - & $\begin{array}{r}-0.5881 \\
(0.635)\end{array}$ & $\begin{array}{r}-0.6447 \\
(0.653)\end{array}$ & $\begin{array}{l}-0.6838 \\
(0.660)\end{array}$ \\
\hline$B R D \_P C T \_I N D$ & - & $\begin{array}{r}-0.8194 \\
(1.612)\end{array}$ & $\begin{array}{r}-0.7950 \\
(1.645)\end{array}$ & $\begin{array}{r}-0.8335 \\
(1.644)\end{array}$ \\
\hline CEOISCHAIR & + & $\begin{array}{l}0.0655 \\
(0.321)\end{array}$ & $\begin{array}{l}0.1504 \\
(0.327)\end{array}$ & $\begin{array}{l}0.1174 \\
(0.322)\end{array}$ \\
\hline CEOFOUNDER & + & $\begin{array}{l}1.1804 * * * \\
(0.497)\end{array}$ & $\begin{array}{l}1.1438 * * * \\
(0.486)\end{array}$ & $\begin{array}{l}1.1196^{* * *} \\
(0.472)\end{array}$ \\
\hline INSTITUTIONAL_OWN & - & $\begin{array}{l}-1.1448 * * \\
(0.497)\end{array}$ & $\begin{array}{l}-1.0932 * * \\
(0.495)\end{array}$ & $\begin{array}{l}-1.1097 * * \\
(0.490)\end{array}$ \\
\hline AUDITOR_SPECIALIST & - & $\begin{array}{l}-0.1536 \\
(0.323)\end{array}$ & $\begin{array}{l}-0.2013 \\
(0.326)\end{array}$ & $\begin{array}{l}-0.1853 \\
(0.324)\end{array}$ \\
\hline LMARKETCAP & + & $\begin{array}{l}0.4659 * * * \\
(0.123)\end{array}$ & $\begin{array}{l}0.4872 * * * \\
(0.127)\end{array}$ & $\begin{array}{l}0.4214 \text { *** } \\
(0.148)\end{array}$ \\
\hline$B M$ & - & $\begin{array}{l}0.5545 * * * \\
(0.185)\end{array}$ & $\begin{array}{l}0.6190 * * * \\
(0.185)\end{array}$ & $\begin{array}{l}0.5760 * * * \\
(0.202)\end{array}$ \\
\hline LEVERAGE & + & $\begin{array}{l}1.9988 * * * \\
(0.753)\end{array}$ & $\begin{array}{l}2.2570 * * * \\
(0.761)\end{array}$ & $\begin{array}{l}2.1371 * * * \\
(0.771)\end{array}$ \\
\hline PCTFORSALES & + & $\begin{array}{l}0.8739 \\
(0.773)\end{array}$ & $\begin{array}{l}0.8848 \\
(0.841)\end{array}$ & $\begin{array}{l}0.8436 \\
(0.856)\end{array}$ \\
\hline ISSUE & + & $\begin{array}{l}0.0283 \\
(0.318)\end{array}$ & $\begin{array}{l}0.0162 \\
(0.320)\end{array}$ & $\begin{array}{l}0.0517 \\
(0.333)\end{array}$ \\
\hline Year Fixed Effects? & & Yes & Yes & Yes \\
\hline Industry Fixed Effects? & & Yes & Yes & Yes \\
\hline Obs. where $M I S C O N D U C T=1$ & & 138 & 138 & 138 \\
\hline Total Obs. & & 1,398 & 1,398 & 1,398 \\
\hline Pseudo $\mathrm{R}^{2}$ & & 0.20 & 0.20 & 0.20 \\
\hline
\end{tabular}


This table reports the results of a logistic regression examining the effect of IAF quality on the likelihood of management misconduct based on the following model:

$$
\operatorname{Prob}(M I S C O N D U C T=1)=\mathrm{F}\left(\beta_{0}+\beta_{1} \text { QUALITY }+ \text { Controls }\right)
$$

The misconduct sample includes (1) violation years from the Federal Securities Regulation Database where fraud or other intentional misconduct is alleged, (2) class period years for settled securities class-action lawsuits per Stanford Securities Class Action Clearinghouse, (3) and violation years for SEC and Department of Justice Enforcement Actions claiming violations of the bribery provisions of the Foreign Corrupt Practices Act of 1977. In columns two and three, the composite IAF quality measure is replaced with underlying components of IAF quality. Specifically, column two includes COMPETENCE and OBJECTIVITY in place of QUALITY, and column three includes EXPERIENCE, CERTIFICATION, TRAINING,NOT_TRAINING_GROUND, INDEPENDENT, and IAF_SIZE in place of QUALITY.

Variable definitions are provided in Appendix A. Standard errors clustered by firm are in parentheses. *, $* *$, and $* * *$ denote statistical significance at the $10 \%, 5 \%$, and $1 \%$ levels, respectively, using a one-tailed test where the coefficient sign is consistent with the predicted direction. 
Table 3, Panel B: Average Marginal Effects of IAF Quality on Management Misconduct

\begin{tabular}{|c|c|c|c|c|}
\hline \multicolumn{5}{|c|}{ Prob $($ MISCONDUCT $=1)=\mathrm{F}\left(\beta_{0}+\beta_{1} Q U A L I T Y+\right.$ Controls $)$} \\
\hline Independent Variables & Predicted Sign & $(1)$ & $(2)$ & $(3)$ \\
\hline QUALITY & - & $\begin{array}{l}-0.0181 * * * \\
(0.008)\end{array}$ & & \\
\hline COMPETENCE & - & & $\begin{array}{l}-0.0208 \text { ** } \\
(0.010)\end{array}$ & \\
\hline OBJECTIVITY & - & & $\begin{array}{l}0.0078 \\
(0.008)\end{array}$ & \\
\hline EXPERIENCE & - & & & $\begin{array}{r}-0.0030 \\
(0.003)\end{array}$ \\
\hline CERTIFICATION & - & & & $\begin{array}{l}-0.0639 * \\
(0.039)\end{array}$ \\
\hline TRAINING & - & & & $\begin{array}{r}-0.0003 \\
(0.000)\end{array}$ \\
\hline NOT_TRAINING_GROUND & - & & & $\begin{array}{l}0.0033 \\
(0.021)\end{array}$ \\
\hline INDEPENDENT & - & & & $\begin{array}{l}0.0113 \\
(0.020)\end{array}$ \\
\hline$I A F \_S I Z E$ & - & & & $\begin{array}{l}-0.0191 \\
(0.020)\end{array}$ \\
\hline ASSISTS_AUDITOR & $?$ & $\begin{array}{l}-0.1695 \\
(0.214)\end{array}$ & $\begin{array}{l}-0.1594 \\
(0.222)\end{array}$ & $\begin{array}{l}-0.1943 \\
(0.224)\end{array}$ \\
\hline$A C \_A C C O U N T I N G \_E X P$ & - & $\begin{array}{r}-0.0386 \\
(0.041)\end{array}$ & $\begin{array}{r}-0.0424 \\
(0.042)\end{array}$ & $\begin{array}{r}-0.0448 \\
(0.043)\end{array}$ \\
\hline$B R D \_P C T \_I N D$ & - & $\begin{array}{l}-0.0537 \\
(0.105)\end{array}$ & $\begin{array}{r}-0.0522 \\
(0.108)\end{array}$ & $\begin{array}{r}-0.0545 \\
(0.107)\end{array}$ \\
\hline CEOISCHAIR & + & $\begin{array}{l}0.0043 \\
(0.021)\end{array}$ & $\begin{array}{l}0.0099 \\
(0.021)\end{array}$ & $\begin{array}{l}0.0077 \\
(0.021)\end{array}$ \\
\hline CEOFOUNDER & + & $\begin{array}{l}0.0993 * * \\
(0.051)\end{array}$ & $\begin{array}{l}0.0954 * * \\
(0.049)\end{array}$ & $\begin{array}{l}0.0922 * * \\
(0.047)\end{array}$ \\
\hline INSTITUTIONAL_OWN & - & $\begin{array}{l}-0.0751 * * * \\
(0.032)\end{array}$ & $\begin{array}{l}-0.0719 * * \\
(0.032)\end{array}$ & $\begin{array}{l}-0.0727 \text { *** } \\
(0.031)\end{array}$ \\
\hline AUDITOR_SPECIALIST & - & $\begin{array}{l}-0.0100 \\
(0.020)\end{array}$ & $\begin{array}{l}-0.0130 \\
(0.020)\end{array}$ & $\begin{array}{r}-0.0120 \\
(0.020)\end{array}$ \\
\hline LMARKETCAP & + & $\begin{array}{l}0.0306 * * * \\
(0.008)\end{array}$ & $\begin{array}{l}0.0320 * * * \\
(0.008)\end{array}$ & $\begin{array}{l}0.0276 \text { *** } \\
(0.009)\end{array}$ \\
\hline$B M$ & - & $\begin{array}{l}0.0364 \text { *** } \\
(0.012)\end{array}$ & $\begin{array}{l}0.0407 * * * \\
(0.012)\end{array}$ & $\begin{array}{l}0.0377 \text { *** } \\
(0.013)\end{array}$ \\
\hline LEVERAGE & + & $\begin{array}{l}0.1311 * * * \\
(0.048)\end{array}$ & $\begin{array}{l}0.1484 * * * \\
(0.048)\end{array}$ & $\begin{array}{l}0.1399 * * * \\
(0.049)\end{array}$ \\
\hline PCTFORSALES & + & $\begin{array}{l}0.0573 \\
(0.051)\end{array}$ & $\begin{array}{l}0.0582 \\
(0.055)\end{array}$ & $\begin{array}{l}0.0552 \\
(0.056)\end{array}$ \\
\hline ISSUE & + & $\begin{array}{l}0.0019 \\
(0.021)\end{array}$ & $\begin{array}{l}0.0011 \\
(0.021)\end{array}$ & $\begin{array}{l}0.0034 \\
(0.022)\end{array}$ \\
\hline Year Fixed Effects? & & Yes & Yes & Yes \\
\hline Industry Fixed Effects? & & Yes & Yes & Yes \\
\hline Obs. where MISCONDUCT $=1$ & & 138 & 138 & 138 \\
\hline Total Obs. & & 1,398 & 1,398 & 1,398 \\
\hline
\end{tabular}


This table reports the average marginal effects for the following logistic regression using the average of discrete or partial changes over all observations (Bartus 2005):

$$
\operatorname{Prob}(M I S C O N D U C T=1)=\mathrm{F}\left(\beta_{0}+\beta_{1} \text { QUALITY }+ \text { Controls }\right)
$$

The misconduct sample includes (1) violation years from the Federal Securities Regulation Database where fraud or other intentional misconduct is alleged, (2) class period years for settled securities class-action lawsuits per Stanford Securities Class Action Clearinghouse, (3) and violation years for SEC and Department of Justice Enforcement Actions claiming violations of the bribery provisions of the Foreign Corrupt Practices Act of 1977. In columns two and three, the composite IAF quality measure is replaced with underlying components of IAF quality. Specifically, column two includes COMPETENCE and OBJECTIVITY in place of QUALITY, and column three includes EXPERIENCE, CERTIFICATION, TRAINING,NOT_TRAINING_GROUND, INDEPENDENT, and IAF_SIZE in place of QUALITY.

Variable definitions are provided in Appendix A. Standard errors clustered by firm are in parentheses. *, $* *$, and $* * *$ denote statistical significance at the $10 \%, 5 \%$, and $1 \%$ levels, respectively, using a one-tailed test where the coefficient sign is consistent with the predicted direction. 
Table 4: Misconduct Firm Response to Revealed Management Misconduct

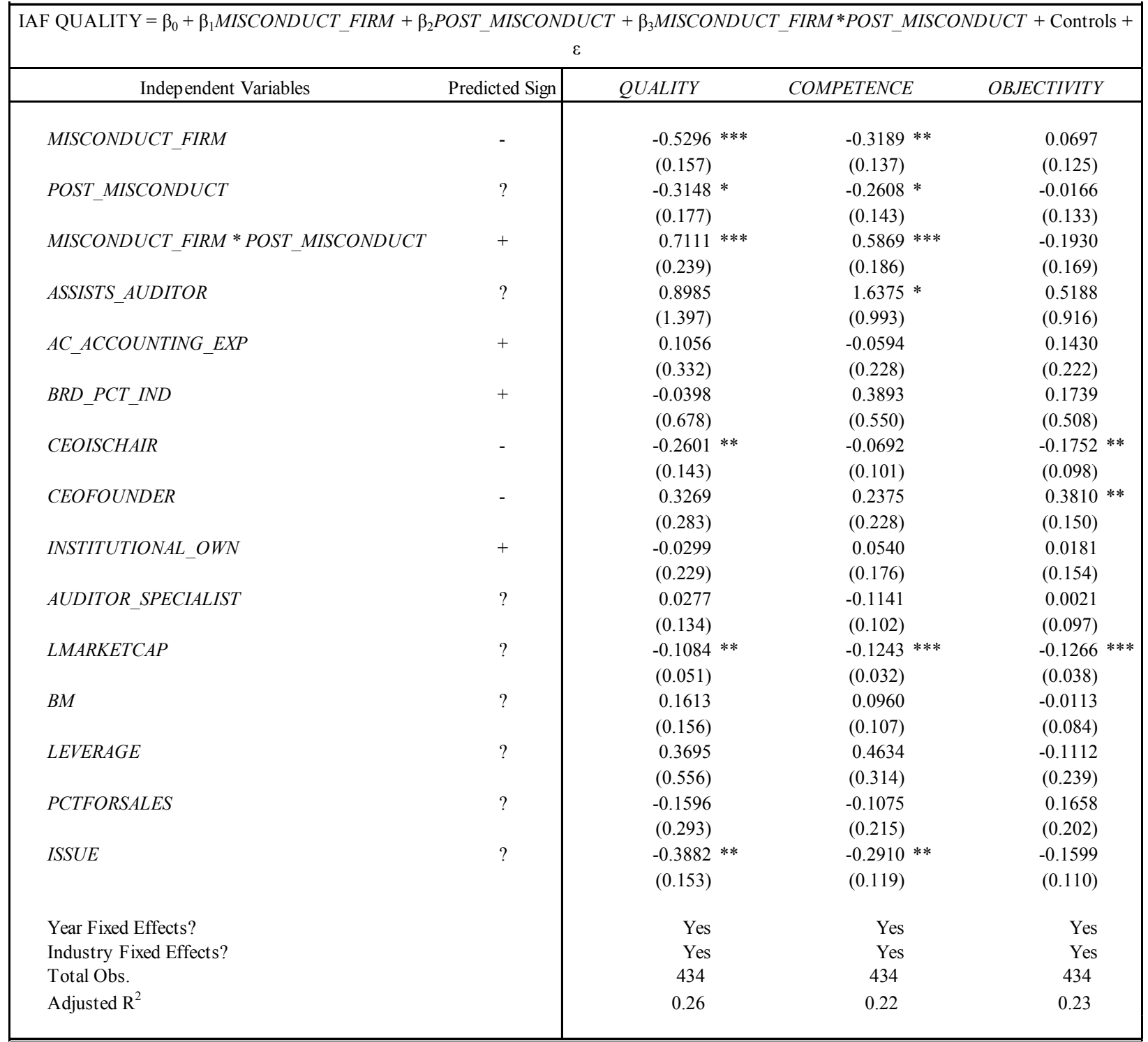


This table reports the results of an ordinary least squares regression examining the response of misconduct firms, as it relates to IAF quality, to revealed management misconduct as compared to a set of control firms. Violation and post-violation firm-years from misconduct firms are matched to firm-years from nonmisconduct firms based upon year, industry, and closest market capitalization. The final sample includes 217 firm-years from misconduct firms, of which 129 are from misconduct years and 88 are from postmisconduct years, and a matched set of 217 firm-years from firms that never had misconduct during the sample period. Utilizing a difference-in-differences design, the response by misconduct firms to revealed misconduct is estimated based upon the following model:

$$
\begin{aligned}
& \text { QUALITY }_{\mathrm{t}}=\beta_{0}+\beta_{1} \text { MISCONDUCT_FIRM }+\beta_{2} \text { POST_MISCONDUCT }+ \\
& \beta_{3} \text { MISCONDUCT_FIRM }{ }_{t} * P O S T \_ \text {MISCONDUCT } T_{t}+\text { Controls }+\varepsilon
\end{aligned}
$$

MISCONDUCT FIRM is an indicator variable that is set to one for observations from a firm that had misconduct during the sample period, and zero otherwise. For example, if firm $i$ had misconduct for years 2003 and 2004 and was in the sample from 2000 through 2009, then MISCONDUCT_FIRM would equal one for all ten firm-years. POST_MISCONDUCT is an indicator variable that is set to one for firm-years from misconduct firms that are subsequent to the violation years (i.e., where MISCONDUCT $=0$ for year $t$, but $M I S C O N D U C T=1$ for year $t-x$ ) and for matched firm-years from the control sample. Column one estimates the effect on IAF quailty; column two estimates the effect on IAF competence; and column three estimates the effect on IAF objectivity.

Variable definitions are provided in Appendix A. Standard errors clustered by firm are in parentheses. *, $* *$, and $* * *$ denote statistical significance at the $10 \%, 5 \%$, and $1 \%$ levels, respectively, using a one-tailed test where the coefficient sign is consistent with the predicted direction. 
Table 5, Panel A: Effect of IAF Quality on Accounting-Related Management Misconduct

\begin{tabular}{|c|c|c|c|c|}
\hline \multicolumn{5}{|c|}{$\operatorname{Prob}\left(A C C O U N T I N G \_M I S=1\right)=\mathrm{F}\left(\beta_{0}+\beta_{1} Q U A L I T Y+\right.$ Controls $)$} \\
\hline Indep endent Variables & Predicted Sign & $(1)$ & $(2)$ & (3) \\
\hline QUALITY & - & $\begin{array}{l}-0.2350 * \\
(0.148)\end{array}$ & & \\
\hline COMPETENCE & - & & $\begin{array}{l}-0.4380 * * \\
(0.256)\end{array}$ & \\
\hline OBJECTIVITY & - & & $\begin{array}{l}0.1675 \\
(0.181)\end{array}$ & \\
\hline EXPERIENCE & - & & & $\begin{array}{r}-0.0795 \\
(0.072)\end{array}$ \\
\hline CERTIFICATION & - & & & $\begin{array}{c}-0.9522 * \\
(0.646)\end{array}$ \\
\hline TRAINING & - & & & $\begin{array}{r}-0.0021 \\
(0.006)\end{array}$ \\
\hline NOT_TRAINING_GROUND & - & & & $\begin{array}{l}0.0258 \\
(0.422)\end{array}$ \\
\hline INDEPENDENT & - & & & $\begin{array}{l}0.6943 \\
(0.503)\end{array}$ \\
\hline$I A F \_S I Z E$ & - & & & $\begin{array}{r}-0.5174 \\
(0.590)\end{array}$ \\
\hline ASSISTS_AUDITOR & $?$ & $\begin{array}{r}-2.6483 \\
(4.020)\end{array}$ & $\begin{array}{r}-2.2197 \\
(3.880)\end{array}$ & $\begin{array}{r}-2.5248 \\
(3.962)\end{array}$ \\
\hline$A C \_A C C O U N T I N G \_E X P$ & - & $\begin{array}{r}-0.4009 \\
(0.893)\end{array}$ & $\begin{array}{r}-0.4757 \\
(0.904)\end{array}$ & $\begin{array}{r}-0.3768 \\
(0.910)\end{array}$ \\
\hline BRD_PCT_IND & - & $\begin{array}{r}-2.3806 \\
(1.894)\end{array}$ & $\begin{array}{l}-2.4267 \\
(1.943)\end{array}$ & $\begin{array}{l}-2.6000 \\
(2.058)\end{array}$ \\
\hline CEOISCHAIR & + & $\begin{array}{l}0.1880 \\
(0.453)\end{array}$ & $\begin{array}{l}0.2921 \\
(0.431)\end{array}$ & $\begin{array}{l}0.3008 \\
(0.442)\end{array}$ \\
\hline CEOFOUNDER & + & $\begin{array}{l}1.2535 * \\
(0.808)\end{array}$ & $\begin{array}{l}1.2041 * \\
(0.795)\end{array}$ & $\begin{array}{l}1.1678 * \\
(0.782)\end{array}$ \\
\hline INSTITUTIONAL_OWN & - & $\begin{array}{l}-1.45555^{* *} \\
(0.711)\end{array}$ & $\begin{array}{l}-1.4583 * * \\
(0.700)\end{array}$ & $\begin{array}{l}-1.5392 * * \\
(0.675)\end{array}$ \\
\hline AUDITOR_SPECIALIST & - & $\begin{array}{r}-0.2968 \\
(0.510)\end{array}$ & $\begin{array}{r}-0.3170 \\
(0.503)\end{array}$ & $\begin{array}{r}-0.2516 \\
(0.509)\end{array}$ \\
\hline LMARKETCAP & + & $\begin{array}{l}0.2055 * \\
(0.137)\end{array}$ & $\begin{array}{l}0.2243 * \\
(0.138)\end{array}$ & $\begin{array}{l}0.1128 \\
(0.151)\end{array}$ \\
\hline$B M$ & - & $\begin{array}{l}0.5826 * \\
(0.301)\end{array}$ & $\begin{array}{l}0.6664 \text { ** } \\
(0.338)\end{array}$ & $\begin{array}{l}0.6459 * * \\
(0.328)\end{array}$ \\
\hline LEVERAGE & + & $\begin{array}{l}1.8058 * * \\
(1.049)\end{array}$ & $\begin{array}{l}2.0873 * * \\
(1.081)\end{array}$ & $\begin{array}{l}2.0128 * * \\
(1.134)\end{array}$ \\
\hline PCTFORSALES & + & $\begin{array}{l}0.4902 \\
(0.768)\end{array}$ & $\begin{array}{l}0.3968 \\
(0.882)\end{array}$ & $\begin{array}{l}0.4426 \\
(0.832)\end{array}$ \\
\hline ISSUE & + & $\begin{array}{l}0.2683 \\
(0.365)\end{array}$ & $\begin{array}{l}0.2328 \\
(0.386)\end{array}$ & $\begin{array}{l}0.2901 \\
(0.396)\end{array}$ \\
\hline Year Fixed Effects? & & Yes & Yes & Yes \\
\hline Industry Fixed Effects? & & Yes & Yes & Yes \\
\hline Obs. where MISCONDUCT $=1$ & & 56 & 56 & 56 \\
\hline Total Obs. & & 1,398 & 1,398 & 1,398 \\
\hline Pseudo $\mathrm{R}^{2}$ & & 0.10 & 0.10 & 0.10 \\
\hline
\end{tabular}


This table reports the results of a logistic regression examining the effect of IAF quality on the likelihood of accounting-related management misconduct based on the following model:

$$
\operatorname{Prob}(\text { ACCOUNTING_MIS }=1)=\mathrm{F}\left(\beta_{0}+\beta_{1} Q U A L I T Y+\text { Controls }\right)
$$

The accounting-related misconduct sample includes (1) violation years from the Federal Securities Regulation Database where fraud or other intentional misconduct is alleged unless the violation stems from a violation of the bribery provision of the Foreign Corrupt Practices Act of 1977 and (2) class period years for settled securities class-action lawsuits that allege violations of Generally Accepted Accounting Principles per Stanford Securities Class Action Clearinghouse. In columns two and three, the composite IAF quality measure is replaced with underlying components of IAF quality. Specifically, column two includes COMPETENCE and OBJECTIVITY in place of QUALITY, and column three includes EXPERIENCE, CERTIFICATION, TRAINING, NOT_TRAINING_GROUND, INDEPENDENT, and $I A F \_S I Z E$ in place of QUALITY.

Variable definitions are provided in Appendix A. Standard errors clustered by firm are in parentheses. *, $* *$, and $* * *$ denote statistical significance at the $10 \%, 5 \%$, and $1 \%$ levels, respectively, using a one-tailed test where the coefficient sign is consistent with the predicted direction. 
Table 5, Panel B: Effect of IAF Quality on Non-Accounting-Related Management Misconduct

\begin{tabular}{|c|c|c|c|c|}
\hline \multicolumn{5}{|c|}{$\operatorname{Prob}\left(N O N A C C O U N T I N G \_M I S=1\right)=\mathrm{F}\left(\beta_{0}+\beta_{1} Q U A L I T Y+\right.$ Controls $)$} \\
\hline Independent Variables & Predicted Sign & $(1)$ & $(2)$ & (3) \\
\hline QUALITY & - & $\begin{array}{c}-0.2218 * \\
(0.148)\end{array}$ & & \\
\hline COMPETENCE & - & & $\begin{array}{r}-0.1178 \\
(0.191)\end{array}$ & \\
\hline OBJECTIVITY & - & & $\begin{array}{l}0.0691 \\
(0.144)\end{array}$ & \\
\hline EXPERIENCE & - & & & $\begin{array}{r}-0.0056 \\
(0.058)\end{array}$ \\
\hline CERTIFICATION & - & & & $\begin{array}{r}-0.8450 \\
(0.795)\end{array}$ \\
\hline TRAINING & - & & & $\begin{array}{l}-0.0048 \\
(0.005)\end{array}$ \\
\hline NOT_TRAINING_GROUND & - & & & $\begin{array}{l}0.2019 \\
(0.397)\end{array}$ \\
\hline INDEPENDENT & - & & & $\begin{array}{r}-0.1658 \\
(0.413)\end{array}$ \\
\hline$I A F \_S I Z E$ & - & & & $\begin{array}{r}-0.2574 \\
(0.304)\end{array}$ \\
\hline ASSISTS_AUDITOR & $?$ & $\begin{array}{l}-2.8367 \\
(5.622)\end{array}$ & $\begin{array}{r}-2.8971 \\
(5.774)\end{array}$ & $\begin{array}{r}-3.5408 \\
(5.680)\end{array}$ \\
\hline AC_ACCOUNTING_EXP & - & $\begin{array}{r}-0.7485 \\
(0.809)\end{array}$ & $\begin{array}{r}-0.7609 \\
(0.818)\end{array}$ & $\begin{array}{r}-0.8604 \\
(0.822)\end{array}$ \\
\hline$B R D \_P C T \_I N D$ & - & $\begin{array}{l}0.7636 \\
(2.504)\end{array}$ & $\begin{array}{l}0.8112 \\
(2.542)\end{array}$ & $\begin{array}{l}0.7821 \\
(2.506)\end{array}$ \\
\hline CEOISCHAIR & + & $\begin{array}{r}-0.0117 \\
(0.412)\end{array}$ & $\begin{array}{l}0.0638 \\
(0.427)\end{array}$ & $\begin{array}{l}0.0150 \\
(0.416)\end{array}$ \\
\hline CEOFOUNDER & + & $\begin{array}{c}0.5262 \\
(0.750)\end{array}$ & $\begin{array}{c}0.5184 \\
(0.747)\end{array}$ & $\begin{array}{l}0.4917 \\
(0.712)\end{array}$ \\
\hline INSTITUTIONAL_OWN & - & $\begin{array}{r}-0.6476 \\
(0.708)\end{array}$ & $\begin{array}{r}-0.6314 \\
(0.706)\end{array}$ & $\begin{array}{r}-0.6121 \\
(0.689)\end{array}$ \\
\hline AUDITOR_SPECIALIST & - & $\begin{array}{r}-0.0419 \\
(0.463)\end{array}$ & $\begin{array}{l}-0.0453 \\
(0.451)\end{array}$ & $\begin{array}{r}-0.0455 \\
(0.448)\end{array}$ \\
\hline LMARKETCAP & + & $\begin{array}{l}0.4818 * * * \\
(0.173)\end{array}$ & $\begin{array}{l}0.5056 * * * \\
(0.180)\end{array}$ & $\begin{array}{l}0.4546^{* *} \\
(0.210)\end{array}$ \\
\hline$B M$ & - & $\begin{array}{l}0.0431 \\
(0.369)\end{array}$ & $\begin{array}{l}0.0137 \\
(0.381)\end{array}$ & $\begin{array}{l}0.0291 \\
(0.369)\end{array}$ \\
\hline LEVERAGE & + & $\begin{array}{l}0.7597 \\
(1.448)\end{array}$ & $\begin{array}{l}0.9672 \\
(1.399)\end{array}$ & $\begin{array}{l}0.8880 \\
(1.408)\end{array}$ \\
\hline PCTFORSALES & + & $\begin{array}{c}0.3972 \\
(0.816)\end{array}$ & $\begin{array}{c}0.4228 \\
(0.846)\end{array}$ & $\begin{array}{l}0.5131 \\
(0.853)\end{array}$ \\
\hline ISSUE & + & $\begin{array}{r}-0.1128 \\
(0.474)\end{array}$ & $\begin{array}{r}-0.0878 \\
(0.470)\end{array}$ & $\begin{array}{r}-0.0912 \\
(0.481)\end{array}$ \\
\hline Year Fixed Effects? & & Yes & Yes & Yes \\
\hline Industry Fixed Effects? & & Yes & Yes & Yes \\
\hline Obs. where MISCONDUCT $=1$ & & 82 & 82 & 82 \\
\hline Total Obs. & & 1,398 & 1,398 & 1,398 \\
\hline Pseudo $\mathrm{R}^{2}$ & & 0.14 & 0.13 & 0.14 \\
\hline
\end{tabular}


This table reports the results of a logistic regression examining the effect of IAF quality on the likelihood of non-accounting-related management misconduct based on the following model:

$$
\operatorname{Prob}\left(N O N A C C O U N T I N G \_M I S=1\right)=\mathrm{F}\left(\beta_{0}+\beta_{1} Q U A L I T Y+\text { Controls }\right)
$$

The non-accounting-related misconduct sample includes (1) class period years for settled securities classaction lawsuits that do not allege violations of Generally Accepted Accounting Principles per Stanford Securities Class Action Clearinghouse and (2) violation years for SEC and Department of Justice Enforcement Actions claiming violation of the bribery provisions of the Foreign Corrupt Practices Act of 1977. In columns two and three, the composite IAF quality measure is replaced with underlying components of IAF quality. Specifically, column two includes COMPETENCE and OBJECTIVITY in place of QUALITY, and column three includes EXPERIENCE, CERTIFICATION, TRAINING, NOT_TRAINING_GROUND, INDEPENDENT, and IAF_SIZE in place of QUALITY.

Variable definitions are provided in Appendix A. Standard errors clustered by firm are in parentheses. *, $* *$, and $* * *$ denote statistical significance at the $10 \%, 5 \%$, and $1 \%$ levels, respectively, using a one-tailed test where the coefficient sign is consistent with the predicted direction. 
Table 6: Predictive Ability of IAF Quality on Accounting-Related Management Misconduct

\begin{tabular}{|c|c|c|c|c|c|}
\hline \multicolumn{6}{|c|}{$\operatorname{Prob}\left(A C C O U N T I N G_{-} M I S=1\right)=\mathrm{F}\left(\beta_{0}+\beta_{1} Q U A L I T Y+\right.$ Controls $)$} \\
\hline Independent Variables & Predicted Sign & $(1)$ & $(2)$ & (3) & $(4)$ \\
\hline QUALITY & - & $\begin{array}{l}-0.5216 * * * \\
(0.172)\end{array}$ & $\begin{array}{l}-0.3149 * \\
(0.202)\end{array}$ & $\begin{array}{l}-0.5767 * * * \\
(0.162)\end{array}$ & $\begin{array}{l}-0.3661 * * \\
(0.211)\end{array}$ \\
\hline FSCORE & + & $\begin{array}{c}49.3260 * * * \\
(9.324)\end{array}$ & $\begin{array}{l}40.6610 * * * \\
(13.526)\end{array}$ & & \\
\hline ASSISTS_AUDITOR & $?$ & & $\begin{array}{r}-5.2965 \\
(7.488)\end{array}$ & & $\begin{array}{r}-9.0807 \\
(10.560)\end{array}$ \\
\hline$A C \_A C C O U N T I N G \_E X P$ & - & & $\begin{array}{r}-1.3379 \\
(1.465)\end{array}$ & & $\begin{array}{r}-1.3776 \\
(1.650)\end{array}$ \\
\hline$B R D \_P C T \_I N D$ & - & & $\begin{array}{r}-1.3827 \\
(3.088)\end{array}$ & & $\begin{array}{r}-2.1901 \\
(3.201)\end{array}$ \\
\hline CEOISCHAIR & + & & $\begin{array}{r}-0.0473 \\
(0.590)\end{array}$ & & $\begin{array}{r}0.1409 \\
(0.660)\end{array}$ \\
\hline CEOFOUNDER & + & & $\begin{array}{l}0.8386 \\
(1.256)\end{array}$ & & $\begin{array}{r}0.6485 \\
(1.495)\end{array}$ \\
\hline INSTITUTIONAL_OWN & - & & $\begin{array}{l}-2.1113 * * \\
(0.999)\end{array}$ & & $\begin{array}{l}-2.3083 * * \\
(1.087)\end{array}$ \\
\hline AUDITOR_SPECIALIST & - & & $\begin{array}{r}-0.5834 \\
(0.608)\end{array}$ & & $\begin{array}{l}-0.6520 \\
(0.617)\end{array}$ \\
\hline LMARKETCAP & + & & $\begin{array}{r}0.0565 \\
(0.176)\end{array}$ & & $\begin{array}{r}0.1410 \\
(0.183)\end{array}$ \\
\hline$B M$ & - & & $\begin{array}{r}0.0932 \\
(0.496)\end{array}$ & & $\begin{array}{r}-0.2490 \\
(0.501)\end{array}$ \\
\hline LEVERAGE & + & & $\begin{array}{l}1.5796 \\
(1.885)\end{array}$ & & $\begin{array}{r}-0.2808 \\
(2.437)\end{array}$ \\
\hline PCTFORSALES & + & & $\begin{array}{r}1.3529 \\
(1.279)\end{array}$ & & $\begin{array}{r}1.5347 \\
(1.373)\end{array}$ \\
\hline$R S S T \_A C C$ & + & & & $\begin{array}{r}1.2882 \\
(1.893)\end{array}$ & $\begin{array}{r}-0.3612 \\
(2.605)\end{array}$ \\
\hline CH_REC & + & & & $\begin{array}{l}7.8632 * \\
(4.923)\end{array}$ & $\begin{array}{l}8.4899 * \\
(5.270)\end{array}$ \\
\hline CH_INV & + & & & $\begin{array}{c}-12.3858 * \\
(6.839)\end{array}$ & $\begin{array}{r}-6.3293 \\
(11.692)\end{array}$ \\
\hline SOFT_ASSETS & + & & & $\begin{array}{r}0.6940 \\
(0.949)\end{array}$ & $\begin{array}{r}1.7776 \\
(1.692)\end{array}$ \\
\hline $\mathrm{CH}_{-} \mathrm{CS}$ & + & & & $\begin{array}{l}0.5834 * * \\
(0.261)\end{array}$ & $\begin{array}{l}0.6237 * * \\
(0.336)\end{array}$ \\
\hline $\mathrm{CH} \mathrm{ROA}_{-}$ & - & & & $\begin{array}{l}-3.6131 * \\
(2.391)\end{array}$ & $\begin{array}{l}-5.7796 * * \\
(2.999)\end{array}$ \\
\hline ISSUE & + & & & $\begin{array}{l}0.3348 \\
(0.486)\end{array}$ & $\begin{array}{l}0.8175 * * \\
(0.455)\end{array}$ \\
\hline CH_EMP & - & & & $\begin{array}{r}-0.4354 \\
(0.619)\end{array}$ & $\begin{array}{l}-0.0125 \\
(1.169)\end{array}$ \\
\hline LEASE & + & & & $\begin{array}{l}-0.9370 * \\
(0.554)\end{array}$ & $\begin{array}{l}-2.5648 * * * \\
(0.875)\end{array}$ \\
\hline$R_{E T U R N_{t}}$ & + & & & $\begin{array}{l}-2.6304 * * * \\
(0.423)\end{array}$ & $\begin{array}{l}-2.2049 * * * \\
(0.744)\end{array}$ \\
\hline$R_{E T U R N_{t-1}}$ & + & & & $\begin{array}{r}-0.3411 \\
(0.559)\end{array}$ & $\begin{array}{l}0.2019 \\
(0.514)\end{array}$ \\
\hline Year Fixed Effects? & & No & Yes & No & Yes \\
\hline Industry Fixed Effects? & & No & Yes & No & Yes \\
\hline Obs. where $M I S C O N D U C T=1$ & & 37 & 37 & 37 & 37 \\
\hline Total Obs. & & 1,044 & 1,044 & 1,044 & 1,044 \\
\hline Pseudo $\mathrm{R}^{2}$ & & 0.03 & 0.11 & 0.04 & 0.13 \\
\hline
\end{tabular}


This table reports the results of a logistic regression examining the effect of IAF quality on the likelihood of accounting-related management misconduct based on the following model:

$$
\operatorname{Prob}(\text { ACCOUNTING_MIS }=1)=\mathrm{F}\left(\beta_{0}+\beta_{1} Q U A L I T Y+\text { Controls }\right)
$$

The accounting-related misconduct sample includes (1) violation years from the Federal Securities Regulation Database where fraud or other intentional misconduct is alleged unless the violation stems from a violation of the bribery provision of the Foreign Corrupt Practices Act of 1977 and (2) class period years for settled securities class-action lawsuits that allege violations of Generally Accepted Accounting Principles per Stanford Securities Class Action Clearinghouse. In column one, I include the F-score based upon Dechow et al. (2011) as a control variable. In column two, I include the F-score and control variables from equation (1). In column three, I include the underlying variables from Dechow et al. (2011) that are used to calculate the F-score. In column four, I include control variables from equation (1) and the underlying variables from Dechow et al. (2011) that are used to calculate the F-score.

Variable defintions are provided in Appendix A. Standard errors clustered by firm are in parentheses. *, **, and $* * *$ denote statistical significance at the $10 \%, 5 \%$, and $1 \%$ levels, respectively, using a one-tailed test where the coefficient sign is consistent with the predicted direction. 
Table 7: Interactive Effect of IAF Competence and Objectivity on Management Misconduct

\begin{tabular}{|c|c|c|}
\hline \multicolumn{3}{|c|}{$\begin{array}{c}\operatorname{Prob}(M I S C O N D U C T=1)=\mathrm{F}\left(\beta_{0}+\beta_{1} C O M P+\beta_{2} O B J+\beta_{3} C O M P^{*} O B J+\right. \\
\text { Controls })\end{array}$} \\
\hline Independent Variables & Predicted Sign & (1) \\
\hline COMP & - & $\begin{array}{l}-0.9292 * * \\
(0.411)\end{array}$ \\
\hline$O B J$ & - & $\begin{array}{l}-0.1256 \\
(0.354)\end{array}$ \\
\hline$C O M P * O B J$ & - & $\begin{array}{r}0.8042 \\
(0.531)\end{array}$ \\
\hline ASSISTS_AUDITOR & ? & $\begin{array}{r}-2.2868 \\
(3.442)\end{array}$ \\
\hline$A C \_A C C O U N T I N G \_E X P$ & - & $\begin{array}{r}-0.6489 \\
(0.642)\end{array}$ \\
\hline$B R D \_P C T \_I N D$ & - & $\begin{array}{r}-0.9278 \\
(1.670)\end{array}$ \\
\hline CEOISCHAIR & + & $\begin{array}{l}0.1482 \\
(0.329)\end{array}$ \\
\hline CEOFOUNDER & + & $\begin{array}{l}1.1970 * * * \\
(0.502)\end{array}$ \\
\hline INSTITUTIONAL_OWN & - & $\begin{array}{l}-1.0728 * * \\
(0.500)\end{array}$ \\
\hline AUDITOR_SPECIALIST & - & $\begin{array}{r}-0.1808 \\
(0.330)\end{array}$ \\
\hline LMARKETCAP & + & $\begin{array}{l}0.4934 * * * \\
(0.127)\end{array}$ \\
\hline$B M$ & - & $\begin{array}{l}0.6191 * * * \\
(0.188)\end{array}$ \\
\hline LEVERAGE & + & $\begin{array}{l}2.1014 * * * \\
(0.767)\end{array}$ \\
\hline PCTFORSALES & + & $\begin{array}{l}0.9168 \\
(0.818)\end{array}$ \\
\hline ISSUE & + & $\begin{array}{l}0.0472 \\
(0.312)\end{array}$ \\
\hline Year Fixed Effects? & & Yes \\
\hline Industry Fixed Effects? & & Yes \\
\hline $\begin{array}{l}\text { Obs. where MISCONDUCT }=1 \\
\text { Total Obs. }\end{array}$ & & $\begin{array}{r}138 \\
1,398\end{array}$ \\
\hline Pseudo $\mathrm{R}^{2}$ & & 0.20 \\
\hline
\end{tabular}


This table reports the results of a logistic regression examining the effect of IAF quality on the likelihood of management misconduct based on the following model:

$$
\operatorname{Prob}(M I S C O N D U C T=1)=\mathrm{F}\left(\beta_{0}+\beta_{1} C O M P+\beta_{2} O B J+\beta_{3} C O M P * O B J+\text { Controls }\right)
$$

The misconduct sample includes (1) violation years from the Federal Securities Regulation Database where fraud or other intentional misconduct is alleged, (2) class period years for settled securities class-action lawsuits per Stanford Securities Class Action Clearinghouse, (3) and violation years for SEC and Department of Justice Enforcement Actions claiming violations of the bribery provisions of the Foreign Corrupt Practices Act of 1977. COMP is an indicator variable that is set to one when COMPETENCE is greater than zero, and zero otherwise. OBJ is an indicator variable that is set to one when OBJECTIVITY is greater than zero, and zero otherwise.

The remaining variable definitions are provided in Appendix A. Standard errors clustered by firm are in parentheses. *, **, and *** denote statistical significance at the $10 \%, 5 \%$, and $1 \%$ levels, respectively, using a one-tailed test where the coefficient sign is consistent with the predicted direction. 
Table 8, Panel A: Effect of IAF Quality on Management Misconduct for 2000 - 2001

\begin{tabular}{|c|c|c|c|c|}
\hline \multicolumn{5}{|c|}{$\operatorname{Prob}($ MISCONDUCT $=1)=\mathrm{F}\left(\beta_{0}+\beta_{1} Q U A L I T Y+\right.$ Controls $)$} \\
\hline Independent Variables & Predicted Sign & (1) & $(2)$ & (3) \\
\hline QUALITY & - & $\begin{array}{l}-0.8501 * * \\
(0.460)\end{array}$ & & \\
\hline COMPETENCE & - & & $\begin{array}{l}-0.8827 * * \\
(0.511)\end{array}$ & \\
\hline OBJECTIVITY & - & & $\begin{array}{l}0.4653 \\
(0.317)\end{array}$ & \\
\hline EXPERIENCE & - & & & $\begin{array}{r}-0.1036 \\
(0.203)\end{array}$ \\
\hline CERTIFICATION & - & & & $\begin{array}{l}-2.4187 * \\
(1.615)\end{array}$ \\
\hline TRAINING & - & & & $\begin{array}{r}-0.0115 \\
(0.009)\end{array}$ \\
\hline NOT_TRAINING_GROUND & - & & & $\begin{array}{r}-0.2398 \\
(0.820)\end{array}$ \\
\hline INDEPENDENT & - & & & $\begin{array}{l}0.8751 \\
(0.819)\end{array}$ \\
\hline$I A F \_S I Z E$ & - & & & $\begin{array}{l}-1.6896 * \\
(1.161)\end{array}$ \\
\hline ASSISTS_AUDITOR & $?$ & $\begin{array}{r}-3.8169 \\
(8.912)\end{array}$ & $\begin{array}{r}-8.0870 \\
(10.456)\end{array}$ & $\begin{array}{c}-7.9967 \\
(10.509)\end{array}$ \\
\hline$A C \_A C C O U N T I N G \_E X P$ & - & $\begin{array}{l}0.0853 \\
(3.090)\end{array}$ & $\begin{array}{l}1.8265 \\
(2.455)\end{array}$ & $\begin{array}{r}1.6230 \\
(2.790)\end{array}$ \\
\hline$B R D \_P C T \_I N D$ & - & $\begin{array}{r}0.1660 \\
(5.513)\end{array}$ & $\begin{array}{l}1.0957 \\
(5.436)\end{array}$ & $\begin{array}{r}0.3883 \\
(5.954)\end{array}$ \\
\hline CEOISCHAIR & + & $\begin{array}{r}-0.6936 \\
(0.749)\end{array}$ & $\begin{array}{r}-0.5497 \\
(0.726)\end{array}$ & $\begin{array}{r}-0.6289 \\
(0.731)\end{array}$ \\
\hline CEOFOUNDER & + & $\begin{array}{c}-12.5081 * * * \\
(2.252)\end{array}$ & $\begin{array}{l}-12.1240 * * * \\
(2.154)\end{array}$ & $\begin{array}{c}-12.6931 * * * \\
(2.252)\end{array}$ \\
\hline INSTITUTIONAL_OWN & - & $\begin{array}{r}-0.6385 \\
(1.088)\end{array}$ & $\begin{array}{r}-1.0999 \\
(1.052)\end{array}$ & $\begin{array}{r}-1.1415 \\
(0.994)\end{array}$ \\
\hline AUDITOR_SPECIALIST & - & $\begin{array}{l}-1.3946 * \\
(0.918)\end{array}$ & $\begin{array}{l}-1.4955 * \\
(0.954)\end{array}$ & $\begin{array}{r}-1.2837 \\
(1.031)\end{array}$ \\
\hline LMARKETCAP & + & $\begin{array}{l}1.1350 \text { *** } \\
(0.384)\end{array}$ & $\begin{array}{l}1.0323 * * * \\
(0.367)\end{array}$ & $\begin{array}{l}0.8666 \text { *** } \\
(0.313)\end{array}$ \\
\hline$B M$ & - & $\begin{array}{l}1.5053 \\
(2.670)\end{array}$ & $\begin{array}{l}0.4179 \\
(2.289)\end{array}$ & $\begin{array}{l}0.0165 \\
(2.715)\end{array}$ \\
\hline LEVERAGE & + & $\begin{array}{l}7.9459 * \\
(5.904)\end{array}$ & $\begin{array}{l}9.1706 * \\
(5.856)\end{array}$ & $\begin{array}{l}9.4071 * \\
(6.601)\end{array}$ \\
\hline PCTFORSALES & + & $\begin{array}{l}3.9143 \\
(3.118)\end{array}$ & $\begin{array}{l}3.9479 \\
(3.517)\end{array}$ & $\begin{array}{l}4.0171 \\
(3.742)\end{array}$ \\
\hline ISSUE & + & $\begin{array}{r}-0.1702 \\
(0.847)\end{array}$ & $\begin{array}{r}-0.0675 \\
(0.965)\end{array}$ & $\begin{array}{r}-0.1354 \\
(1.063)\end{array}$ \\
\hline Year Fixed Effects? & & Yes & Yes & Yes \\
\hline Industry Fixed Effects? & & Yes & Yes & Yes \\
\hline Obs. where $M I S C O N D U C T=1$ & & 39 & 39 & 39 \\
\hline Total Obs. & & 176 & 176 & 176 \\
\hline Pseudo $\mathrm{R}^{2}$ & & 0.41 & 0.42 & 0.43 \\
\hline
\end{tabular}


This table reports the results of a logistic regression examining the effect of IAF quality on the likelihood of management misconduct based on the following model for calendar years 2000 through 2001:

$$
\operatorname{Prob}(M I S C O N D U C T=1)=\mathrm{F}\left(\beta_{0}+\beta_{1} \text { QUALITY }+ \text { Controls }\right)
$$

The misconduct sample includes (1) violation years from the Federal Securities Regulation Database where fraud or other intentional misconduct is alleged, (2) class period years for settled securities class-action lawsuits per Stanford Securities Class Action Clearinghouse, (3) and violation years for SEC and Department of Justice Enforcement Actions claiming violations of the bribery provisions of the Foreign Corrupt Practices Act of 1977. In columns two and three, the composite IAF quality measure is replaced with underlying components of IAF quality. Specifically, column two includes COMPETENCE and OBJECTIVITY in place of QUALITY, and column three includes EXPERIENCE, CERTIFICATION, TRAINING,NOT_TRAINING_GROUND, INDEPENDENT, and IAF_SIZE in place of QUALITY.

Variable definitions are provided in Appendix A. Standard errors clustered by firm are in parentheses. *, $* *$, and $* * *$ denote statistical significance at the $10 \%, 5 \%$, and $1 \%$ levels, respectively, using a one-tailed test where the coefficient sign is consistent with the predicted direction. 
Table 8, Panel B: Effect of IAF Quality on Management Misconduct for 2000 - 2003

\begin{tabular}{|c|c|c|c|c|}
\hline \multicolumn{5}{|c|}{$\operatorname{Prob}(M I S C O N D U C T=1)=\mathrm{F}\left(\beta_{0}+\beta_{1} Q U A L I T Y+\right.$ Controls $)$} \\
\hline Independent Variables & Predicted Sign & $(1)$ & $(2)$ & $(3)$ \\
\hline QUALITY & - & $\begin{array}{l}-0.4680 \text { ** } \\
(0.202)\end{array}$ & & \\
\hline COMPETENCE & - & & $\begin{array}{l}-0.5689 * * \\
(0.285)\end{array}$ & \\
\hline OВJECTIVITY & - & & $\begin{array}{l}0.2825 \\
(0.230)\end{array}$ & \\
\hline EXPERIENCE & - & & & $\begin{array}{r}-0.0739 \\
(0.090)\end{array}$ \\
\hline CERTIFICATION & - & & & $\begin{array}{l}-2.0401 * * \\
(0.950)\end{array}$ \\
\hline TRAINING & - & & & $\begin{array}{l}-0.0144 * * \\
(0.007)\end{array}$ \\
\hline NOT_TRAINING_GROUND & - & & & $\begin{array}{l}0.1193 \\
(0.552)\end{array}$ \\
\hline INDEPENDENT & - & & & $\begin{array}{c}0.1328 \\
(0.509)\end{array}$ \\
\hline$I A F \_S I Z E$ & - & & & $\begin{array}{l}-1.4136 * * \\
(0.733)\end{array}$ \\
\hline ASSISTS_AUDITOR & $?$ & $\begin{array}{r}-2.7989 \\
(5.820)\end{array}$ & $\begin{array}{r}-2.4247 \\
(7.598)\end{array}$ & $\begin{array}{r}-4.4541 \\
(6.641)\end{array}$ \\
\hline$A C \_A C C O U N T I N G \_E X P$ & - & $\begin{array}{r}-1.0855 \\
(1.233)\end{array}$ & $\begin{array}{r}-0.7964 \\
(1.233)\end{array}$ & $\begin{array}{r}-1.0501 \\
(1.250)\end{array}$ \\
\hline$B R D \_P C T \_I N D$ & - & $\begin{array}{l}1.1021 \\
(2.825)\end{array}$ & $\begin{array}{l}1.3153 \\
(2.904)\end{array}$ & $\begin{array}{l}1.0625 \\
(2.658)\end{array}$ \\
\hline CEOISCHAIR & + & $\begin{array}{c}-0.8527 * \\
(0.572)\end{array}$ & $\begin{array}{r}-0.5739 \\
(0.634)\end{array}$ & $\begin{array}{r}-0.6762 \\
(0.674)\end{array}$ \\
\hline CEOFOUNDER & + & $\begin{array}{c}1.6691 \\
(1.409)\end{array}$ & $\begin{array}{l}1.5306 \\
(1.361)\end{array}$ & $\begin{array}{c}1.2422 \\
(1.350)\end{array}$ \\
\hline INSTITUTIONAL_OWN & - & $\begin{array}{l}-1.4279 * \\
(0.985)\end{array}$ & $\begin{array}{r}-1.2996 \\
(1.048)\end{array}$ & $\begin{array}{l}-1.4709 * \\
(0.998)\end{array}$ \\
\hline AUDITOR_SPECIALIST & - & $\begin{array}{l}-0.4975 \\
(0.472)\end{array}$ & $\begin{array}{r}-0.5622 \\
(0.475)\end{array}$ & $\begin{array}{r}-0.4416 \\
(0.480)\end{array}$ \\
\hline LMARKETCAP & + & $\begin{array}{l}0.6720 \text { *** } \\
(0.178)\end{array}$ & $\begin{array}{l}0.7145 * * * \\
(0.193)\end{array}$ & $\begin{array}{l}0.5583 \text { *** } \\
(0.187)\end{array}$ \\
\hline$B M$ & - & $\begin{array}{l}0.5382 \\
(0.451)\end{array}$ & $\begin{array}{l}0.5777 \\
(0.465)\end{array}$ & $\begin{array}{l}0.3464 \\
(0.544)\end{array}$ \\
\hline LEVERAGE & + & $\begin{array}{l}5.2542 * * * \\
(2.028)\end{array}$ & $\begin{array}{l}6.1531 * * * \\
(2.094)\end{array}$ & $\begin{array}{l}6.1030 \text { *** } \\
(2.311)\end{array}$ \\
\hline PCTFORSALES & + & $\begin{array}{l}3.6716^{* *} \\
(1.863)\end{array}$ & $\begin{array}{l}3.4730 * * \\
(1.929)\end{array}$ & $\begin{array}{l}3.5377 * * \\
(1.987)\end{array}$ \\
\hline ISSUE & + & $\begin{array}{l}0.1207 \\
(0.464)\end{array}$ & $\begin{array}{c}0.1608 \\
(0.480)\end{array}$ & $\begin{array}{c}0.1881 \\
(0.525)\end{array}$ \\
\hline Year Fixed Effects? & & Yes & Yes & Yes \\
\hline Industry Fixed Effects? & & Yes & Yes & Yes \\
\hline Obs. where $M I S C O N D U C T=1$ & & 74 & 74 & 74 \\
\hline Total Obs. & & 364 & 364 & 364 \\
\hline Pseudo $\mathrm{R}^{2}$ & & 0.33 & 0.34 & 0.35 \\
\hline
\end{tabular}


This table reports the results of a logistic regression examining the effect of IAF quality on the likelihood of management misconduct based on the following model for calendar years 2000 through 2003:

$$
\operatorname{Prob}(M I S C O N D U C T=1)=\mathrm{F}\left(\beta_{0}+\beta_{1} \text { QUALITY }+ \text { Controls }\right)
$$

The misconduct sample includes (1) violation years from the Federal Securities Regulation Database where fraud or other intentional misconduct is alleged, (2) class period years for settled securities class-action lawsuits per Stanford Securities Class Action Clearinghouse, (3) and violation years for SEC and Department of Justice Enforcement Actions claiming violations of the bribery provisions of the Foreign Corrupt Practices Act of 1977. In columns two and three, the composite IAF quality measure is replaced with underlying components of IAF quality. Specifically, column two includes COMPETENCE and OBJECTIVITY in place of QUALITY, and column three includes EXPERIENCE, CERTIFICATION, TRAINING,NOT_TRAINING_GROUND, INDEPENDENT, and IAF_SIZE in place of QUALITY.

Variable definitions are provided in Appendix A. Standard errors clustered by firm are in parentheses. *, $* *$, and $* * *$ denote statistical significance at the $10 \%, 5 \%$, and $1 \%$ levels, respectively, using a one-tailed test where the coefficient sign is consistent with the predicted direction. 
Table 8, Panel C: Effect of IAF Quality on Management Misconduct for 2000 - 2005

\begin{tabular}{|c|c|c|c|c|}
\hline \multicolumn{5}{|c|}{$\operatorname{Prob}(M I S C O N D U C T=1)=\mathrm{F}\left(\beta_{0}+\beta_{1} Q U A L I T Y+\right.$ Controls $)$} \\
\hline Independent Variables & Predicted Sign & $(1)$ & $(2)$ & $(3)$ \\
\hline QUALITY & - & $\begin{array}{l}-0.3252 * * * \\
(0.137)\end{array}$ & & \\
\hline COMPETENCE & - & & $\begin{array}{l}-0.3293 * \\
(0.207)\end{array}$ & \\
\hline OВJECTIVITY & - & & $\begin{array}{c}0.2268 \\
(0.174)\end{array}$ & \\
\hline EXPERIENCE & - & & & $\begin{array}{r}-0.0220 \\
(0.062)\end{array}$ \\
\hline CERTIFICATION & - & & & $\begin{array}{l}-1.4975 * * \\
(0.758)\end{array}$ \\
\hline TRAINING & - & & & $\begin{array}{l}-0.0080 * \\
(0.005)\end{array}$ \\
\hline NOT_TRAINING_GROUND & - & & & $\begin{array}{r}0.0614 \\
(0.391)\end{array}$ \\
\hline INDEPENDENT & - & & & $\begin{array}{c}0.2182 \\
(0.375)\end{array}$ \\
\hline$I A F \_S I Z E$ & - & & & $\begin{array}{l}-0.5578 * \\
(0.396)\end{array}$ \\
\hline ASSISTS_AUDITOR & $?$ & $\begin{array}{r}-0.4185 \\
(4.868)\end{array}$ & $\begin{array}{r}0.0237 \\
(5.397)\end{array}$ & $\begin{array}{r}-1.2310 \\
(5.337)\end{array}$ \\
\hline$A C \_A C C O U N T I N G \_E X P$ & - & $\begin{array}{l}-1.2525 * \\
(0.849)\end{array}$ & $\begin{array}{l}-1.2564 * \\
(0.866)\end{array}$ & $\begin{array}{l}-1.4001 * \\
(0.873)\end{array}$ \\
\hline$B R D \_P C T \_I N D$ & - & $\begin{array}{l}-0.6196 \\
(2.006)\end{array}$ & $\begin{array}{r}-0.6475 \\
(2.063)\end{array}$ & $\begin{array}{l}-0.6315 \\
(2.006)\end{array}$ \\
\hline CEOISCHAIR & + & $\begin{array}{r}-0.1871 \\
(0.388)\end{array}$ & $\begin{array}{r}-0.0165 \\
(0.409)\end{array}$ & $\begin{array}{r}-0.0851 \\
(0.416)\end{array}$ \\
\hline CEOFOUNDER & + & $\begin{array}{c}0.8504 \\
(0.826)\end{array}$ & $\begin{array}{c}0.7463 \\
(0.788)\end{array}$ & $\begin{array}{c}0.7218 \\
(0.726)\end{array}$ \\
\hline INSTITUTIONAL_OWN & - & $\begin{array}{l}-1.2341 \text { ** } \\
(0.667)\end{array}$ & $\begin{array}{l}-1.2390 * * \\
(0.678)\end{array}$ & $\begin{array}{l}-1.2093 \text { ** } \\
(0.649)\end{array}$ \\
\hline AUDITOR_SPECIALIST & - & $\begin{array}{l}-0.0631 \\
(0.373)\end{array}$ & $\begin{array}{l}-0.0930 \\
(0.381)\end{array}$ & $\begin{array}{r}-0.0570 \\
(0.374)\end{array}$ \\
\hline LMARKETCAP & + & $\begin{array}{l}0.4669 \text { *** } \\
(0.148)\end{array}$ & $\begin{array}{l}0.5147 \text { *** } \\
(0.158)\end{array}$ & $\begin{array}{l}0.4066^{* * *} \\
(0.172)\end{array}$ \\
\hline$B M$ & - & $\begin{array}{l}0.5844 \\
(0.378)\end{array}$ & $\begin{array}{l}0.6608 * \\
(0.385)\end{array}$ & $\begin{array}{l}0.5186 \\
(0.394)\end{array}$ \\
\hline LEVERAGE & + & $\begin{array}{l}3.5336 * * * \\
(1.212)\end{array}$ & $\begin{array}{l}3.8615 * * * \\
(1.205)\end{array}$ & $\begin{array}{l}3.5559 * * * \\
(1.230)\end{array}$ \\
\hline PCTFORSALES & + & $\begin{array}{l}1.7187 * \\
(1.070)\end{array}$ & $\begin{array}{l}1.6892 * \\
(1.138)\end{array}$ & $\begin{array}{l}1.6667 * \\
(1.155)\end{array}$ \\
\hline ISSUE & + & $\begin{array}{r}-0.0539 \\
(0.373)\end{array}$ & $\begin{array}{r}-0.0309 \\
(0.370)\end{array}$ & $\begin{array}{c}0.0362 \\
(0.387)\end{array}$ \\
\hline Year Fixed Effects? & & Yes & Yes & Yes \\
\hline Industry Fixed Effects? & & Yes & Yes & Yes \\
\hline Obs. where $M I S C O N D U C T=1$ & & 103 & 103 & 103 \\
\hline Total Obs. & & 698 & 698 & 698 \\
\hline Pseudo $\mathrm{R}^{2}$ & & 0.24 & 0.24 & 0.25 \\
\hline
\end{tabular}


This table reports the results of a logistic regression examining the effect of IAF quality on the likelihood of management misconduct based on the following model for calendar years 2000 through 2005:

$$
\operatorname{Prob}(M I S C O N D U C T=1)=\mathrm{F}\left(\beta_{0}+\beta_{1} \text { QUALITY }+ \text { Controls }\right)
$$

The misconduct sample includes (1) violation years from the Federal Securities Regulation Database where fraud or other intentional misconduct is alleged, (2) class period years for settled securities class-action lawsuits per Stanford Securities Class Action Clearinghouse, (3) and violation years for SEC and Department of Justice Enforcement Actions claiming violations of the bribery provisions of the Foreign Corrupt Practices Act of 1977. In columns two and three, the composite IAF quality measure is replaced with underlying components of IAF quality. Specifically, column two includes COMPETENCE and OBJECTIVITY in place of QUALITY, and column three includes EXPERIENCE, CERTIFICATION, TRAINING,NOT_TRAINING_GROUND, INDEPENDENT, and IAF_SIZE in place of QUALITY.

Variable definitions are provided in Appendix A. Standard errors clustered by firm are in parentheses. *, $* *$, and $* * *$ denote statistical significance at the $10 \%, 5 \%$, and $1 \%$ levels, respectively, using a one-tailed test where the coefficient sign is consistent with the predicted direction. 
Table 8, Panel D: Effect of IAF Quality on Management Misconduct for 2002 - 2009

\begin{tabular}{|c|c|c|c|c|}
\hline \multicolumn{5}{|c|}{$\operatorname{Prob}(M I S C O N D U C T=1)=\mathrm{F}\left(\beta_{0}+\beta_{1} Q U A L I T Y+\right.$ Controls $)$} \\
\hline Independent Variables & Predicted Sign & (1) & (2) & (3) \\
\hline QUALITY & - & $\begin{array}{c}-0.2130 * \\
(0.137)\end{array}$ & & \\
\hline COMPETENCE & - & & $\begin{array}{l}-0.2644 * \\
(0.179)\end{array}$ & \\
\hline OBJECTIVITY & - & & $\begin{array}{l}0.0421 \\
(0.147)\end{array}$ & \\
\hline EXPERIENCE & - & & & $\begin{array}{r}-0.0236 \\
(0.046)\end{array}$ \\
\hline CERTIFICATION & - & & & $\begin{array}{l}-0.9519 * \\
(0.682)\end{array}$ \\
\hline TRAINING & - & & & $\begin{array}{l}-0.0001 \\
(0.005)\end{array}$ \\
\hline NOT_TRAINING_GROUND & - & & & $\begin{array}{l}-0.0045 \\
(0.364)\end{array}$ \\
\hline INDEPENDENT & - & & & $\begin{array}{l}0.2390 \\
(0.419)\end{array}$ \\
\hline$I A F \_S I Z E$ & - & & & $\begin{array}{r}-0.2562 \\
(0.302)\end{array}$ \\
\hline ASSISTS_AUDITOR & $?$ & $\begin{array}{r}-2.9192 \\
(3.230)\end{array}$ & $\begin{array}{r}-2.8169 \\
(3.249)\end{array}$ & $\begin{array}{r}-3.4131 \\
(3.395)\end{array}$ \\
\hline$A C \_A C C O U N T I N G \_E X P$ & - & $\begin{array}{l}-1.0904 * \\
(0.722)\end{array}$ & $\begin{array}{l}-1.1972 * \\
(0.747)\end{array}$ & $\begin{array}{l}-1.2369 * \\
(0.752)\end{array}$ \\
\hline BRD_PCT_IND & - & $\begin{array}{r}-1.3210 \\
(1.840)\end{array}$ & $\begin{array}{r}-1.3992 \\
(1.864)\end{array}$ & $\begin{array}{r}-1.5907 \\
(1.912)\end{array}$ \\
\hline CEOISCHAIR & + & $\begin{array}{l}0.1941 \\
(0.360)\end{array}$ & $\begin{array}{l}0.2241 \\
(0.367)\end{array}$ & $\begin{array}{l}0.1760 \\
(0.369)\end{array}$ \\
\hline CEOFOUNDER & + & $\begin{array}{l}1.1863 \text { *** } \\
(0.451)\end{array}$ & $\begin{array}{l}1.1697 \text { *** } \\
(0.441)\end{array}$ & $\begin{array}{l}1.1860 \text { *** } \\
(0.428)\end{array}$ \\
\hline INSTITUTIONAL_OWN & - & $\begin{array}{l}-1.2770 * * * \\
(0.518)\end{array}$ & $\begin{array}{l}-1.2174 * * * \\
(0.514)\end{array}$ & $\begin{array}{l}-1.2279 * * * \\
(0.506)\end{array}$ \\
\hline AUDITOR_SPECIALIST & - & $\begin{array}{l}0.1100 \\
(0.357)\end{array}$ & $\begin{array}{l}0.0451 \\
(0.355)\end{array}$ & $\begin{array}{l}0.0379 \\
(0.356)\end{array}$ \\
\hline LMARKETCAP & + & $\begin{array}{l}0.4393 * * * \\
(0.126)\end{array}$ & $\begin{array}{l}0.4510 * * * \\
(0.129)\end{array}$ & $\begin{array}{l}0.3801 * * * \\
(0.160)\end{array}$ \\
\hline$B M$ & - & $\begin{array}{l}0.5367 * * * \\
(0.175)\end{array}$ & $\begin{array}{l}0.5896 * * * \\
(0.170)\end{array}$ & $\begin{array}{l}0.5548 * * * \\
(0.178)\end{array}$ \\
\hline LEVERAGE & + & $\begin{array}{l}1.4435 * * \\
(0.817)\end{array}$ & $\begin{array}{l}1.6474 * * \\
(0.831)\end{array}$ & $\begin{array}{l}1.4517 * * \\
(0.868)\end{array}$ \\
\hline PCTFORSALES & + & $\begin{array}{l}0.3689 \\
(0.728)\end{array}$ & $\begin{array}{l}0.3510 \\
(0.791)\end{array}$ & $\begin{array}{l}0.3209 \\
(0.749)\end{array}$ \\
\hline ISSUE & + & $\begin{array}{l}0.1012 \\
(0.365)\end{array}$ & $\begin{array}{c}0.0681 \\
(0.368)\end{array}$ & $\begin{array}{l}0.1388 \\
(0.385)\end{array}$ \\
\hline Year Fixed Effects? & & Yes & Yes & Yes \\
\hline Industry Fixed Effects? & & Yes & Yes & Yes \\
\hline Obs. where $M I S C O N D U C T=1$ & & 99 & 99 & 99 \\
\hline Total Obs. & & 1,222 & 1,222 & 1,222 \\
\hline Pseudo $\mathrm{R}^{2}$ & & 0.18 & 0.18 & 0.18 \\
\hline
\end{tabular}


This table reports the results of a logistic regression examining the effect of IAF quality on the likelihood of management misconduct based on the following model for calendar years 2002 through 2009:

$$
\operatorname{Prob}(M I S C O N D U C T=1)=\mathrm{F}\left(\beta_{0}+\beta_{1} \text { QUALITY }+ \text { Controls }\right)
$$

The misconduct sample includes (1) violation years from the Federal Securities Regulation Database where fraud or other intentional misconduct is alleged, (2) class period years for settled securities class-action lawsuits per Stanford Securities Class Action Clearinghouse, (3) and violation years for SEC and Department of Justice Enforcement Actions claiming violations of the bribery provisions of the Foreign Corrupt Practices Act of 1977. In columns two and three, the composite IAF quality measure is replaced with underlying components of IAF quality. Specifically, column two includes COMPETENCE and OBJECTIVITY in place of QUALITY, and column three includes EXPERIENCE, CERTIFICATION, TRAINING,NOT_TRAINING_GROUND, INDEPENDENT, and IAF_SIZE in place of QUALITY.

Variable definitions are provided in Appendix A. Standard errors clustered by firm are in parentheses. *, $* *$, and $* * *$ denote statistical significance at the $10 \%, 5 \%$, and $1 \%$ levels, respectively, using a one-tailed test where the coefficient sign is consistent with the predicted direction. 
Table 9: Effect of IAF Quality on Management Misconduct Controlling for Different External Auditor Quality Definitions

\begin{tabular}{|c|c|c|c|}
\hline \multicolumn{4}{|c|}{$\operatorname{Prob}($ MISCONDUCT $=1)=\mathrm{F}\left(\beta_{0}+\beta_{1} Q U A L I T Y+\right.$ Controls $)$} \\
\hline Indep endent Variables & Predicted Sign & $(1)$ & $(2)$ \\
\hline QUALITY & - & $\begin{array}{l}-0.2650 * * \\
(0.119)\end{array}$ & $\begin{array}{l}-0.2717 * * \\
(0.121)\end{array}$ \\
\hline ASSISTS_AUDITOR & $?$ & $\begin{array}{l}-2.1967 \\
(3.191)\end{array}$ & $\begin{array}{l}-2.2518 \\
(3.196)\end{array}$ \\
\hline$A C \_A C C O U N T I N G \_E X P$ & - & $\begin{array}{l}-0.6407 \\
(0.644)\end{array}$ & $\begin{array}{r}-0.5905 \\
(0.640)\end{array}$ \\
\hline$B R D \_P C T \_I N D$ & - & $\begin{array}{r}-0.8145 \\
(1.609)\end{array}$ & $\begin{array}{r}-0.7142 \\
(1.611)\end{array}$ \\
\hline CEOISCHAIR & + & $\begin{array}{l}0.0584 \\
(0.316)\end{array}$ & $\begin{array}{r}0.0397 \\
(0.316)\end{array}$ \\
\hline CEOFOUNDER & + & $\begin{array}{l}1.1370 * * \\
(0.494)\end{array}$ & $\begin{array}{l}1.1597 * * * \\
(0.492)\end{array}$ \\
\hline INSTITUTIONAL_OWN & - & $\begin{array}{l}-1.1228 * * * \\
(0.479)\end{array}$ & $\begin{array}{l}-1.1678 * * * \\
(0.486)\end{array}$ \\
\hline CITY_SPECIALIST & - & $\begin{array}{l}0.3984 \\
(0.283)\end{array}$ & \\
\hline JOINT_SPECIALIST & - & & $\begin{array}{l}0.1664 \\
(0.335)\end{array}$ \\
\hline LMARKETCAP & + & $\begin{array}{l}0.4228 * * * \\
(0.124)\end{array}$ & $\begin{array}{l}0.4520 * * * \\
(0.121)\end{array}$ \\
\hline$B M$ & - & $\begin{array}{l}0.5225 * * * \\
(0.187)\end{array}$ & $\begin{array}{l}0.5431 * * * \\
(0.180)\end{array}$ \\
\hline LEVERAGE & + & $\begin{array}{l}1.9387 * * * \\
(0.739)\end{array}$ & $\begin{array}{l}1.9376 * * * \\
(0.755)\end{array}$ \\
\hline PCTFORSALES & + & $\begin{array}{l}0.9056 \\
(0.804)\end{array}$ & $\begin{array}{l}0.8722 \\
(0.771)\end{array}$ \\
\hline ISSUE & + & $\begin{array}{r}0.0592 \\
(0.315)\end{array}$ & $\begin{array}{r}0.0605 \\
(0.321)\end{array}$ \\
\hline Year Fixed Effects? & & Yes & Yes \\
\hline Industry Fixed Effects? & & Yes & Yes \\
\hline Obs. where MISCONDUCT $=1$ & & 138 & 138 \\
\hline Total Obs. & & 1,398 & 1,398 \\
\hline Pseudo $\mathrm{R}^{2}$ & & 0.20 & 0.20 \\
\hline
\end{tabular}


This table reports the results of a logistic regression examining the effect of IAF quality on the likelihood of management misconduct based on the following model:

$$
\operatorname{Prob}(M I S C O N D U C T=1)=\mathrm{F}\left(\beta_{0}+\beta_{1} \text { QUALITY }+ \text { Controls }\right)
$$

The misconduct sample includes (1) violation years from the Federal Securities Regulation Database where fraud or other intentional misconduct is alleged, (2) class period years for settled securities class-action lawsuits per Stanford Securities Class Action Clearinghouse, (3) and violation years for SEC and Department of Justice Enforcement Actions claiming violations of the bribery provisions of the Foreign Corrupt Practices Act of 1977. CITY_SPECIALIST is set to one for year $t$ when the firm is audited by the external auditor with the highest industry market share based upon the city where the firm's corporate headquarters is located. JOINT_SPECIALIST is set to one when the external auditor is both a national and a city industry expert (i.e., when both AUDITOR_SPECIALIST and CITY_SPECIALIST are equal to one) for year $t$.

The remaining variable definitions are provided in Appendix A. Standard errors clustered by firm are in parentheses. *, **, and *** denote statistical significance at the $10 \%, 5 \%$, and $1 \%$ levels, respectively, using a one-tailed test where the coefficient sign is consistent with the predicted direction. 
Table 10: Effect of IAF Quality on Management Misconduct Controlling for Internal Control Quality

\begin{tabular}{|c|c|c|c|c|}
\hline \multicolumn{5}{|c|}{ Prob $($ MISCONDUCT $=1)=\mathrm{F}\left(\beta_{0}+\beta_{1} Q U A L I T Y+\right.$ Controls $)$} \\
\hline Indep endent Variables & Predicted Sign & $(1)$ & $(2)$ & (3) \\
\hline QUALITY & - & $\begin{array}{l}-0.2874 * * \\
(0.142)\end{array}$ & & \\
\hline COMPETENCE & - & & $\begin{array}{c}-0.3856 \text { ** } \\
(0.184)\end{array}$ & \\
\hline OBJECTIVITY & - & & $\begin{array}{l}0.0079 \\
(0.152)\end{array}$ & \\
\hline EXPERIENCE & - & & & $\begin{array}{r}-0.0440 \\
(0.048)\end{array}$ \\
\hline CERTIFICATION & - & & & $\begin{array}{c}-1.0710 * \\
(0.699)\end{array}$ \\
\hline TRAINING & - & & & $\begin{array}{c}0.0003 \\
(0.005)\end{array}$ \\
\hline NOT_TRAINING_GROUND & - & & & $\begin{array}{r}-0.0975 \\
(0.364)\end{array}$ \\
\hline INDEPENDENT & - & & & $\begin{array}{l}0.1899 \\
(0.422)\end{array}$ \\
\hline IAF_SIZE & - & & & $\begin{array}{r}-0.2874 \\
(0.285)\end{array}$ \\
\hline$M W$ & $?$ & $\begin{array}{l}1.1138 \text { ** } \\
(0.456)\end{array}$ & $\begin{array}{l}1.2012 \text { *** } \\
(0.456)\end{array}$ & $\begin{array}{l}1.2389 \text { *** } \\
(0.447)\end{array}$ \\
\hline ASSISTS_AUDITOR & ? & $\begin{array}{l}-2.3305 \\
(3.170)\end{array}$ & $\begin{array}{l}-2.3027 \\
(3.164)\end{array}$ & $\begin{array}{r}-2.9751 \\
(3.337)\end{array}$ \\
\hline$A C \_A C C O U N T I N G \_E X P$ & - & $\begin{array}{c}-0.9732 * \\
(0.714)\end{array}$ & $\begin{array}{l}-1.0514 * \\
(0.744)\end{array}$ & $\begin{array}{c}-1.0881 * \\
(0.746)\end{array}$ \\
\hline$B R D_{-} P C T_{-} I N D$ & - & $\begin{array}{r}-1.3528 \\
(1.908)\end{array}$ & $\begin{array}{r}-1.4395 \\
(1.944)\end{array}$ & $\begin{array}{r}-1.6524 \\
(1.986)\end{array}$ \\
\hline CEOISCHAIR & + & $\begin{array}{l}0.2388 \\
(0.394)\end{array}$ & $\begin{array}{l}0.2762 \\
(0.402)\end{array}$ & $\begin{array}{l}0.2298 \\
(0.403)\end{array}$ \\
\hline CEOFOUNDER & + & $\begin{array}{l}1.2660 \text { *** } \\
(0.458)\end{array}$ & $\begin{array}{l}1.2461 * * * \\
(0.456)\end{array}$ & $\begin{array}{l}1.2570 \text { *** } \\
(0.447)\end{array}$ \\
\hline INSTITUTIONAL_OWN & - & $\begin{array}{l}-1.2108^{* * *} \\
(0.512)\end{array}$ & $\begin{array}{l}-1.1191 * * \\
(0.507)\end{array}$ & $\begin{array}{l}-1.1183 \text { ** } \\
(0.500)\end{array}$ \\
\hline AUDITOR_SPECIALIST & - & $\begin{array}{l}-0.0354 \\
(0.353)\end{array}$ & $\begin{array}{l}-0.1198 \\
(0.353)\end{array}$ & $\begin{array}{r}-0.1250 \\
(0.354)\end{array}$ \\
\hline LMARKETCAP & + & $\begin{array}{l}0.4938^{* * *} \\
(0.135)\end{array}$ & $\begin{array}{l}0.5006 * * * \\
(0.143)\end{array}$ & $\begin{array}{l}0.4292 \text { *** } \\
(0.173)\end{array}$ \\
\hline$B M$ & - & $\begin{array}{l}0.5239 \text { *** } \\
(0.195)\end{array}$ & $\begin{array}{l}0.6068 * * * \\
(0.180)\end{array}$ & $\begin{array}{l}0.5742 * * * \\
(0.185)\end{array}$ \\
\hline LEVERAGE & + & $\begin{array}{l}1.0577 \\
(0.871)\end{array}$ & $\begin{array}{l}1.3491 * \\
(0.885)\end{array}$ & $\begin{array}{l}1.1936 * \\
(0.913)\end{array}$ \\
\hline PCTFORSALES & + & $\begin{array}{l}0.1846 \\
(0.750)\end{array}$ & $\begin{array}{c}0.1216 \\
(0.848)\end{array}$ & $\begin{array}{l}0.0735 \\
(0.778)\end{array}$ \\
\hline ISSUE & + & $\begin{array}{l}0.1354 \\
(0.371)\end{array}$ & $\begin{array}{l}0.0708 \\
(0.373)\end{array}$ & $\begin{array}{l}0.1388 \\
(0.395)\end{array}$ \\
\hline Year Fixed Effects? & & Yes & Yes & Yes \\
\hline Industry Fixed Effects? & & Yes & Yes & Yes \\
\hline Obs. where MISCONDUCT $=1$ & & 96 & 96 & 96 \\
\hline Total Obs. & & 1,195 & 1,195 & 1,195 \\
\hline Pseudo $\mathrm{R}^{2}$ & & 0.18 & 0.18 & 0.19 \\
\hline
\end{tabular}


This table reports the results of a logistic regression examining the effect of IAF quality on the likelihood of management misconduct based on the following model which includes a control for internal control quality:

$$
\operatorname{Prob}(\text { MISCONDUCT }=1)=\mathrm{F}\left(\beta_{0}+\beta_{1} \text { QUALITY }+ \text { Controls }\right)
$$

The misconduct sample includes (1) violation years from the Federal Securities Regulation Database where fraud or other intentional misconduct is alleged, (2) class period years for settled securities class-action lawsuits per Stanford Securities Class Action Clearinghouse, (3) and violation years for SEC and Department of Justice Enforcement Actions claiming violations of the bribery provisions of the Foreign Corrupt Practices Act of 1977. In columns two and three, the composite IAF quality measure is replaced with underlying components of IAF quality. Specifically, column two includes COMPETENCE and OBJECTIVITY in place of QUALITY, and column three includes EXPERIENCE, CERTIFICATION, TRAINING, NOT_TRAINING_GROUND, INDEPENDENT, and IAF_SIZE in place of QUALITY. MW is equal to one for firm-years for which a SOX Section 302 or 404 disclosure indicates a material weakness in internal control over financial reporting existed.

The remaining variable definitions are provided in Appendix A. Standard errors clustered by firm are in parentheses. *, **, and *** denote statistical significance at the $10 \%, 5 \%$, and $1 \%$ levels, respectively, using a one-tailed test where the coefficient sign is consistent with the predicted direction. 
Table 11: Changes in IAF Quality Characteristics in Response to Revealed Management Misconduct

\begin{tabular}{|c|c|c|c|c|c|c|c|}
\hline Independent Variables & Predicted Sign & EXPERIENCE & CERTIFICATION & TRAINING & NOT_TRAINING_GROUND & INDEPENDENT & $I A F \_S I Z E$ \\
\hline MISCONDUCT_FIRM & - & $\begin{array}{l}-0.9392 * \\
(0.581)\end{array}$ & $\begin{array}{l}-0.1038 * * * \\
(0.044)\end{array}$ & $\begin{array}{r}-1.4328 \\
(3.952)\end{array}$ & $\begin{array}{r}-0.0273 \\
(0.076)\end{array}$ & $\begin{array}{l}-0.0035 \\
(0.049)\end{array}$ & $\begin{array}{l}-0.0194 \\
(0.080)\end{array}$ \\
\hline POST_MISCONDUCT & ? & $\begin{array}{c}-0.8690 \\
(0.561)\end{array}$ & $\begin{array}{l}-0.0863 * \\
(0.045)\end{array}$ & $\begin{array}{r}-1.3866 \\
(4.403)\end{array}$ & $\begin{array}{r}-0.0073 \\
(0.072)\end{array}$ & $\begin{array}{l}-0.0424 \\
(0.054)\end{array}$ & $\begin{array}{r}-0.0691 \\
(0.088)\end{array}$ \\
\hline MISCONDUCT_FIRM * POST_MISCONDUCT & + & $\begin{array}{l}1.4089 \text { ** } \\
(0.696)\end{array}$ & $\begin{array}{l}0.19711^{* * *} \\
(0.059)\end{array}$ & $\begin{array}{r}5.2369 \\
(5.963)\end{array}$ & $\begin{array}{l}0.0926 \\
(0.100)\end{array}$ & $\begin{array}{r}-0.0028 \\
(0.066)\end{array}$ & $\begin{array}{r}-0.0148 \\
(0.115)\end{array}$ \\
\hline Controls? & & Yes & Yes & Yes & Yes & Yes & Yes \\
\hline Year Fixed Effects? & & Yes & Yes & Yes & Yes & Yes & Yes \\
\hline Industry Fixed Effects? & & Yes & Yes & Yes & Yes & Yes & Yes \\
\hline Total Obs. & & 434 & 434 & 434 & 434 & 434 & 434 \\
\hline Adjusted $\mathrm{R}^{2}$ & & 0.20 & 0.14 & 0.13 & 0.17 & 0.18 & 0.35 \\
\hline
\end{tabular}

This table reports the results of an ordinary least squares regression examining the response of misconduct firms, as it relates to measures of IAF quality, to revealed management misconduct as compared to a set of control firms. Violation and post-violation firm-years from misconduct firms are matched to firm-years from non-misconduct firms based upon year, industry, and closest market capitalization. The final sample includes 217 firm-years from misconduct firms, of which 129 are from misconduct years and 88 are from post-misconduct years, and a matched set of 217 firm-years from firms that never had misconduct during the sample period. Utilizing a difference-in-differences design, the response by misconduct firms to revealed misconduct is estimated based upon the following model:

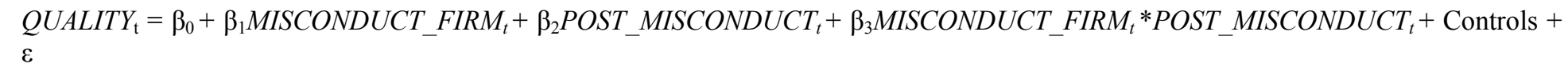

MISCONDUCT_FIRM is an indicator variable that is set to one for observations from a firm that had misconduct during the sample period, and zero otherwise. For example, if firm $i$ had misconduct for years 2003 and 2004 and was in the sample from 2000 through 2009, then MISCONDUCT FIRM would equal one for all ten firm-years. POST_MISCONDUCT is an indicator variable that is set to one for firm-years from misconduct firms that are subsequent to the violation years (i.e., where $\bar{M} I S C O N D U C T=0$ for year $t$, but $M I S C O N D U C T=1$ for year $t-x$ ) and for matched firm-years from the control sample. Column one estimates the effect on IAF experience; column two estimates the effect on IAF certification; column three estimates the effect on IAF training; column four estimates the effect on not using the IAF as a management training ground; column five estimates the effect on the independence of the IAF; and column six estimates the effect on the industry-adjusted IAF size. Control varaibles are included in the regression but not presented in the table for parsimony.

Variable definitions are provided in Appendix A. Standard errors clustered by firm are in parentheses. ${ }^{*}, * *$, and ${ }^{* * *}$ denote statistical significance at the $10 \%, 5 \%$, and $1 \%$ levels, respectively, using a one-tailed test where the coefficient sign is consistent with the predicted direction. 
Table 12: Effect of IAF Quality on Management Misconduct Controlling for IAF Outsourcing

\begin{tabular}{|c|c|c|c|c|}
\hline \multicolumn{5}{|c|}{ Prob $(M I S C O N D U C T=1)=\mathrm{F}\left(\beta_{0}+\beta_{1} Q U A L I T Y+\right.$ Controls $)$} \\
\hline Independent Variables & Predicted Sign & (1) & (2) & (3) \\
\hline QUALITY & - & $\begin{array}{l}-0.2720 * * \\
(0.122)\end{array}$ & & \\
\hline COMPETENCE & - & & $\begin{array}{l}-0.3165 * * \\
(0.163)\end{array}$ & \\
\hline OBJECTIVITY & - & & $\begin{array}{l}0.1089 \\
(0.122)\end{array}$ & \\
\hline EXPERIENCE & - & & & $\begin{array}{r}-0.0449 \\
(0.047)\end{array}$ \\
\hline CERTIFICATION & - & & & $\begin{array}{l}-0.98777^{* *} \\
(0.598)\end{array}$ \\
\hline TRAINING & - & & & $\begin{array}{r}-0.0031 \\
(0.004)\end{array}$ \\
\hline NOT_TRAINING_GROUND & - & & & $\begin{array}{l}0.0589 \\
(0.321)\end{array}$ \\
\hline INDEPENDENT & - & & & $\begin{array}{l}0.2026 \\
(0.321)\end{array}$ \\
\hline$I A F \_S I Z E$ & - & & & $\begin{array}{l}-0.3566 \\
(0.315)\end{array}$ \\
\hline OUTSOURCED & $?$ & $\begin{array}{l}0.1551 \\
(0.173)\end{array}$ & $\begin{array}{l}0.1610 \\
(0.173)\end{array}$ & $\begin{array}{l}0.2078 \\
(0.175)\end{array}$ \\
\hline ASSISTS_AUDITOR & $?$ & $\begin{array}{l}-2.4421 \\
(3.293)\end{array}$ & $\begin{array}{l}-2.2616 \\
(3.382)\end{array}$ & $\begin{array}{l}-2.7867 \\
(3.437)\end{array}$ \\
\hline$A C \_A C C O U N T I N G \_E X P$ & - & $\begin{array}{l}-0.5868 \\
(0.641)\end{array}$ & $\begin{array}{r}-0.6392 \\
(0.658)\end{array}$ & $\begin{array}{l}-0.6677 \\
(0.669)\end{array}$ \\
\hline BRD_PCT_IND & - & $\begin{array}{l}-0.6410 \\
(1.593)\end{array}$ & $\begin{array}{l}-0.6046 \\
(1.626)\end{array}$ & $\begin{array}{l}-0.5984 \\
(1.637)\end{array}$ \\
\hline CEOISCHAIR & + & $\begin{array}{l}0.0933 \\
(0.323)\end{array}$ & $\begin{array}{l}0.1724 \\
(0.328)\end{array}$ & $\begin{array}{l}0.1389 \\
(0.324)\end{array}$ \\
\hline CEOFOUNDER & + & $\begin{array}{l}1.1607 \text { *** } \\
(0.493)\end{array}$ & $\begin{array}{l}1.1261 \text { *** } \\
(0.483)\end{array}$ & $\begin{array}{l}1.1084 \text { *** } \\
(0.470)\end{array}$ \\
\hline INSTITUTIONAL_OWN & - & $\begin{array}{l}-1.1460 * * \\
(0.494)\end{array}$ & $\begin{array}{l}-1.0972 * * \\
(0.493)\end{array}$ & $\begin{array}{l}-1.1219 * * \\
(0.487)\end{array}$ \\
\hline AUDITOR_SPECIALIST & - & $\begin{array}{l}-0.1678 \\
(0.320)\end{array}$ & $\begin{array}{l}-0.2175 \\
(0.325)\end{array}$ & $\begin{array}{l}-0.2022 \\
(0.322)\end{array}$ \\
\hline LMARKETCAP & + & $\begin{array}{l}0.4846 * * * \\
(0.121)\end{array}$ & $\begin{array}{l}0.5054 \text { *** } \\
(0.127)\end{array}$ & $\begin{array}{l}0.4306 \text { *** } \\
(0.149)\end{array}$ \\
\hline$B M$ & - & $\begin{array}{l}0.5542 * * * \\
(0.191)\end{array}$ & $\begin{array}{l}0.6185 * * * \\
(0.191)\end{array}$ & $\begin{array}{l}0.5604 * * * \\
(0.213)\end{array}$ \\
\hline LEVERAGE & + & $\begin{array}{l}2.0517 \text { *** } \\
(0.750)\end{array}$ & $\begin{array}{l}2.2996 \text { *** } \\
(0.760)\end{array}$ & $\begin{array}{l}2.1825 * * * \\
(0.772)\end{array}$ \\
\hline PCTFORSALES & + & $\begin{array}{l}0.9227 \\
(0.745)\end{array}$ & $\begin{array}{l}0.9335 \\
(0.811)\end{array}$ & $\begin{array}{l}0.9128 \\
(0.820)\end{array}$ \\
\hline ISSUE & + & $\begin{array}{l}0.0067 \\
(0.320)\end{array}$ & $\begin{array}{r}-0.0071 \\
(0.320)\end{array}$ & $\begin{array}{l}0.0271 \\
(0.333)\end{array}$ \\
\hline Year Fixed Effects? & & Yes & Yes & Yes \\
\hline Industry Fixed Effects? & & Yes & Yes & Yes \\
\hline Obs. where MISCONDUCT $=1$ & & 138 & 138 & 138 \\
\hline Total Obs. & & 1,398 & 1,398 & 1,398 \\
\hline Pseudo $\mathrm{R}^{2}$ & & 0.20 & 0.20 & 0.20 \\
\hline
\end{tabular}


This table reports the results of a logistic regression examining the effect of IAF quality on the likelihood of management misconduct based on the following model which includes a control for the percentage of IAF work that is outsourced:

$$
\operatorname{Prob}(\text { MISCONDUCT }=1)=\mathrm{F}\left(\beta_{0}+\beta_{1} \text { QUALITY }+ \text { Controls }\right)
$$

The misconduct sample includes (1) violation years from the Federal Securities Regulation Database where fraud or other intentional misconduct is alleged, (2) class period years for settled securities class-action lawsuits per Stanford Securities Class Action Clearinghouse, (3) and violation years for SEC and Department of Justice Enforcement Actions claiming violations of the bribery provisions of the Foreign Corrupt Practices Act of 1977. In columns two and three, the composite IAF quality measure is replaced with underlying components of IAF quality. Specifically, column two includes COMPETENCE and OBJECTIVITY in place of QUALITY, and column three includes EXPERIENCE, CERTIFICATION, TRAINING, NOT_TRAINING_GROUND, INDEPENDENT, and IAF_SIZE in place of QUALITY. OUTSOURCED is a composite measure of the extent to which the IAF is outsourced. The variable can range from zero to four. It is set to zero when there is zero outsourcing or co-sourcing of the IAF; it is set to one when there is more than zero and up to 25 percent outsourcing or co-sourcing of the IAF; it is set to two when there is more than 25 percent and up to 50 percent outsourcing or co-sourcing of the IAF; it is set to three when there is more than 50 percent and less than 100 percent outsourcing or co-sourcing of the IAF; it is set to four when there is 100 percent outsourcing or co-sourcing of the IAF.

The remaining variable definitions are provided in Appendix A. Standard errors clustered by firm are in parentheses. *, $* *$, and $* * *$ denote statistical significance at the $10 \%, 5 \%$, and $1 \%$ levels, respectively, using a one-tailed test where the coefficient sign is consistent with the predicted direction. 
Table 13, Panel A: Effect of IAF Quality on Accounting-Related Management Misconduct Controlling for IAF Focus

\begin{tabular}{|c|c|c|c|c|}
\hline \multicolumn{5}{|c|}{$\operatorname{Prob}\left(A C C O U N T I N G_{-} M I S=1\right)=\mathrm{F}\left(\beta_{0}+\beta_{1} Q U A L I T Y+\right.$ Controls $)$} \\
\hline Independent Variables & Predicted Sign & $(1)$ & $(2)$ & (3) \\
\hline QUALITY & - & $\begin{array}{r}-0.1669 \\
(0.190)\end{array}$ & & \\
\hline COMPETENCE & - & & $\begin{array}{l}-0.4322 * \\
(0.336)\end{array}$ & \\
\hline OBJECTIVITY & - & & $\begin{array}{l}0.3746 \\
(0.228)\end{array}$ & \\
\hline EXPERIENCE & - & & & $\begin{array}{r}-0.0731 \\
(0.102)\end{array}$ \\
\hline CERTIFICATION & - & & & $\begin{array}{c}-1.1369 * \\
(0.818)\end{array}$ \\
\hline TRAINING & - & & & $\begin{array}{r}-0.0046 \\
(0.007)\end{array}$ \\
\hline NOT_TRAINING_GROUND & - & & & $\begin{array}{l}0.0216 \\
(0.488)\end{array}$ \\
\hline INDEPENDENT & - & & & $\begin{array}{c}1.2913 \\
(0.558)\end{array}$ \\
\hline$I A F \_S I Z E$ & - & & & $\begin{array}{l}-0.9403 * \\
(0.725)\end{array}$ \\
\hline FINANCIAL_FOCUS & $?$ & $\begin{array}{r}-0.0263 \\
(0.645)\end{array}$ & $\begin{array}{r}-0.0266 \\
(0.640)\end{array}$ & $\begin{array}{l}0.0442 \\
(0.632)\end{array}$ \\
\hline ASSISTS_AUDITOR & $?$ & $\begin{array}{l}1.6471 \\
(6.469)\end{array}$ & $\begin{array}{l}2.3315 \\
(6.196)\end{array}$ & $\begin{array}{l}1.3847 \\
(6.373)\end{array}$ \\
\hline$A C_{-} A C C O U N T I N G_{-} E X P$ & - & $\begin{array}{r}-0.5326 \\
(1.119)\end{array}$ & $\begin{array}{l}-0.4511 \\
(1.070)\end{array}$ & $\begin{array}{l}-0.0763 \\
(1.024)\end{array}$ \\
\hline$B R D \_P C T \_I N D$ & - & $\begin{array}{l}-3.0066 \\
(2.967)\end{array}$ & $\begin{array}{l}-2.7657 \\
(3.165)\end{array}$ & $\begin{array}{l}-3.4573 \\
(3.125)\end{array}$ \\
\hline CEOISCHAIR & + & $\begin{array}{l}0.2205 \\
(0.530)\end{array}$ & $\begin{array}{l}0.4141 \\
(0.514)\end{array}$ & $\begin{array}{l}0.4127 \\
(0.508)\end{array}$ \\
\hline CEOFOUNDER & + & $\begin{array}{c}1.2765 \\
(1.380)\end{array}$ & $\begin{array}{r}0.9220 \\
(1.274)\end{array}$ & $\begin{array}{r}0.8316 \\
(1.336)\end{array}$ \\
\hline INSTITUTIONAL_OWN & - & $\begin{array}{l}-1.3154 * \\
(0.992)\end{array}$ & $\begin{array}{l}-1.4621 * \\
(0.953)\end{array}$ & $\begin{array}{l}-1.53911^{* *} \\
(0.911)\end{array}$ \\
\hline AUDITOR_SPECIALIST & - & $\begin{array}{r}-0.4261 \\
(0.533)\end{array}$ & $\begin{array}{l}-0.3735 \\
(0.548)\end{array}$ & $\begin{array}{r}-0.3081 \\
(0.546)\end{array}$ \\
\hline LMARKETCAP & + & $\begin{array}{l}0.2909 * * \\
(0.157)\end{array}$ & $\begin{array}{l}0.3672 \text { *** } \\
(0.156)\end{array}$ & $\begin{array}{l}0.2273 * \\
(0.159)\end{array}$ \\
\hline$B M$ & - & $\begin{array}{l}0.5808 \\
(0.489)\end{array}$ & $\begin{array}{l}0.6068 \\
(0.540)\end{array}$ & $\begin{array}{l}0.5188 \\
(0.512)\end{array}$ \\
\hline LEVERAGE & + & $\begin{array}{l}3.2315 * * \\
(1.655)\end{array}$ & $\begin{array}{l}3.7797 * * \\
(1.719)\end{array}$ & $\begin{array}{l}3.9231 \text { ** } \\
(1.836)\end{array}$ \\
\hline PCTFORSALES & + & $\begin{array}{r}1.5533 \\
(1.318)\end{array}$ & $\begin{array}{r}1.5826 \\
(1.334)\end{array}$ & $\begin{array}{r}1.3133 \\
(1.468)\end{array}$ \\
\hline ISSUE & + & $\begin{array}{l}0.3920 \\
(0.428)\end{array}$ & $\begin{array}{l}0.2619 \\
(0.482)\end{array}$ & $\begin{array}{l}0.2838 \\
(0.497)\end{array}$ \\
\hline Year Fixed Effects? & & Yes & Yes & Yes \\
\hline Industry Fixed Effects? & & Yes & Yes & Yes \\
\hline Obs. where $M I S C O N D U C T=1$ & & 40 & 40 & 40 \\
\hline Total Obs. & & 691 & 691 & 691 \\
\hline Pseudo $\mathrm{R}^{2}$ & & 0.12 & 0.13 & 0.14 \\
\hline
\end{tabular}


This table reports the results of a logistic regression examining the effect of IAF quality on the likelihood of accounting-related management misconduct based on the following model which includes a control for the finanical focus of the IAF:

$$
\operatorname{Prob}\left(A C C O U N T I N G \_M I S=1\right)=\mathrm{F}\left(\beta_{0}+\beta_{1} Q U A L I T Y+\text { Controls }\right)
$$

The accounting-related misconduct sample includes (1) violation years from the Federal Securities Regulation Database where fraud or other intentional misconduct is alleged unless the violation stems from a violation of the bribery provision of the Foreign Corrupt Practices Act of 1977 and (2) class period years for settled securities class-action lawsuits that allege violations of Generally Accepted Accounting Principles per Stanford Securities Class Action Clearinghouse. In columns two and three, the composite IAF quality measure is replaced with underlying components of IAF quality. Specifically, column two includes COMPETENCE and OBJECTIVITY in place of QUALITY, and column three includes EXPERIENCE, CERTIFICATION, TRAINING, NOT_TRAINING_GROUND, INDEPENDENT, and IAF_SIZE in place of QUALITY. FINANCIAL_FOCUS is an average of five survey questions that rate the frequency with which the IAF audits financial accounting activities. The audit activities are (1) the adequacy of internal accounting controls, (2) the accuracy, reliability, and completeness of financial records, (3) the impact of changes in accounting rules or regulations, (4) interim financial results that are reported externally, and (5) Generally Accepted Accounting Principles. The responses for each of the activities are never $(=0)$, occasionally $(=1)$, and regularly $(=2)$. These questions are only asked for surveys from 2001 through 2006. Thus, this analysis includes firm-years from 2000 through 2005.

Variable definitions are provided in Appendix A. Standard errors clustered by firm are in parentheses. *, $* *$, and $* * *$ denote statistical significance at the $10 \%, 5 \%$, and $1 \%$ levels, respectively, using a one-tailed test where the coefficient sign is consistent with the predicted direction. 
Table 13, Panel B: Effect of IAF Quality on Non-Accounting-Related Management Misconduct Controlling for IAF Focus

\begin{tabular}{|c|c|c|c|c|}
\hline \multicolumn{5}{|c|}{$\operatorname{Prob}\left(N O N A C C O U N T I N G_{-} M I S=1\right)=\mathrm{F}\left(\beta_{0}+\beta_{1} Q U A L I T Y+\right.$ Controls $)$} \\
\hline Independent Variables & Predicted Sign & (1) & (2) & (3) \\
\hline QUALITY & - & $\begin{array}{l}-0.3120 * * \\
(0.173)\end{array}$ & & \\
\hline COMPETENCE & - & & $\begin{array}{r}-0.0979 \\
(0.226)\end{array}$ & \\
\hline OBJECTIVITY & - & & $\begin{array}{l}0.0700 \\
(0.196)\end{array}$ & \\
\hline EXPERIENCE & - & & & $\begin{array}{l}0.0333 \\
(0.074)\end{array}$ \\
\hline CERTIFICATION & - & & & $\begin{array}{c}-1.6099 * \\
(0.988)\end{array}$ \\
\hline TRAINING & - & & & $\begin{array}{r}-0.0061 \\
(0.006)\end{array}$ \\
\hline NOT_TRAINING_GROUND & - & & & $\begin{array}{l}0.2757 \\
(0.457)\end{array}$ \\
\hline INDEPENDENT & - & & & $\begin{array}{l}-0.4620 \\
(0.481)\end{array}$ \\
\hline$I A F \_S I Z E$ & - & & & $\begin{array}{l}-0.3687 \\
(0.373)\end{array}$ \\
\hline FINANCIAL_FOCUS & $?$ & $\begin{array}{r}-0.4004 \\
(0.554)\end{array}$ & $\begin{array}{r}-0.4726 \\
(0.559)\end{array}$ & $\begin{array}{l}-0.5595 \\
(0.564)\end{array}$ \\
\hline ASSISTS_AUDITOR & $?$ & $\begin{array}{r}-1.3508 \\
(8.508)\end{array}$ & $\begin{array}{r}-1.0053 \\
(9.751)\end{array}$ & $\begin{array}{r}-2.5368 \\
(9.210)\end{array}$ \\
\hline$A C \_A C C O U N T I N G \_E X P$ & - & $\begin{array}{l}-1.5850 * \\
(1.185)\end{array}$ & $\begin{array}{r}-1.5529 \\
(1.221)\end{array}$ & $\begin{array}{l}-2.0131 * * \\
(1.158)\end{array}$ \\
\hline BRD_PCT_IND & - & $\begin{array}{l}1.4904 \\
(2.961)\end{array}$ & $\begin{array}{l}1.8085 \\
(2.863)\end{array}$ & $\begin{array}{l}2.0298 \\
(2.869)\end{array}$ \\
\hline CEOISCHAIR & + & $\begin{array}{l}-0.4259 \\
(0.437)\end{array}$ & $\begin{array}{r}-0.2818 \\
(0.475)\end{array}$ & $\begin{array}{l}-0.3824 \\
(0.478)\end{array}$ \\
\hline CEOFOUNDER & + & $\begin{array}{l}-0.2730 \\
(1.154)\end{array}$ & $\begin{array}{l}-0.2024 \\
(1.150)\end{array}$ & $\begin{array}{l}-0.3052 \\
(1.195)\end{array}$ \\
\hline INSTITUTIONAL_OWN & - & $\begin{array}{l}-0.9426 \\
(0.910)\end{array}$ & $\begin{array}{l}-0.9293 \\
(0.906)\end{array}$ & $\begin{array}{l}-0.9316 \\
(0.881)\end{array}$ \\
\hline AUDITOR_SPECIALIST & - & $\begin{array}{l}0.2359 \\
(0.544)\end{array}$ & $\begin{array}{l}0.2357 \\
(0.534)\end{array}$ & $\begin{array}{l}0.2165 \\
(0.523)\end{array}$ \\
\hline LMARKETCAP & + & $\begin{array}{l}0.4560 \text { *** } \\
(0.170)\end{array}$ & $\begin{array}{l}0.5221 \text { *** } \\
(0.187)\end{array}$ & $\begin{array}{l}0.4381 \text { ** } \\
(0.201)\end{array}$ \\
\hline$B M$ & - & $\begin{array}{l}0.3029 \\
(0.598)\end{array}$ & $\begin{array}{l}0.2884 \\
(0.598)\end{array}$ & $\begin{array}{l}0.0667 \\
(0.678)\end{array}$ \\
\hline LEVERAGE & + & $\begin{array}{l}0.6707 \\
(1.982)\end{array}$ & $\begin{array}{l}1.1023 \\
(2.015)\end{array}$ & $\begin{array}{c}0.7282 \\
(1.948)\end{array}$ \\
\hline PCTFORSALES & + & $\begin{array}{l}1.2547 \\
(1.202)\end{array}$ & $\begin{array}{l}1.5217 * \\
(1.182)\end{array}$ & $\begin{array}{l}1.5729 * \\
(1.210)\end{array}$ \\
\hline ISSUE & + & $\begin{array}{r}-0.2012 \\
(0.496)\end{array}$ & $\begin{array}{r}-0.1534 \\
(0.480)\end{array}$ & $\begin{array}{r}-0.1402 \\
(0.507)\end{array}$ \\
\hline Year Fixed Effects? & & Yes & Yes & Yes \\
\hline Industry Fixed Effects? & & Yes & Yes & Yes \\
\hline Obs. where MISCONDUCT $=1$ & & 62 & 62 & 62 \\
\hline Total Obs. & & 691 & 691 & 691 \\
\hline Pseudo $\mathrm{R}^{2}$ & & 0.19 & 0.19 & 0.20 \\
\hline
\end{tabular}


This table reports the results of a logistic regression examining the effect of IAF quality on the likelihood of non-accounting-related management misconduct based on the following model which includes a control for the finanical focus of the IAF:

$$
\operatorname{Prob}\left(N O N A C C O U N T I N G \_M I S=1\right)=\mathrm{F}\left(\beta_{0}+\beta_{1} Q U A L I T Y+\text { Controls }\right)
$$

The non-accounting-related misconduct sample includes (1) class period years for settled securities classaction lawsuits that do not allege violations of Generally Accepted Accounting Principles per Stanford Securities Class Action Clearinghouse and (2) violation years for SEC and Department of Justice Enforcement Actions claiming violation of the bribery provisions of the Foreign Corrupt Practices Act of 1977. In columns two and three, the composite IAF quality measure is replaced with underlying components of IAF quality. Specifically, column two includes COMPETENCE and OBJECTIVITY in place of QUALITY, and column three includes EXPERIENCE, CERTIFICATION, TRAINING, NOT_TRAINING_GROUND, INDEPENDENT, and IAF_SIZE in place of QUALITY. FINANCIAL_FOCUS is an average of five survey questions that rate the frequency with which the IAF audits financial accounting activities. The audit activities are (1) the adequacy of internal accounting controls, (2) the accuracy, reliability, and completeness of financial records, (3) the impact of changes in accounting rules or regulations, (4) interim financial results that are reported externally, and (5) Generally Accepted Accounting Principles. The responses for each of the activities are never $(=0)$, occasionally $(=1)$, and regularly $(=2)$. These questions are only asked for surveys from 2001 through 2006 . Thus, this analysis includes firm-years from 2000 through 2005.

Variable definitions are provided in Appendix A. Standard errors clustered by firm are in parentheses. *, $* *$, and $* *$ denote statistical significance at the $10 \%, 5 \%$, and $1 \%$ levels, respectively, using a one-tailed test where the coefficient sign is consistent with the predicted direction. 


\section{Appendix A - Variable Definitions}

\begin{tabular}{|l|l|l|}
\hline \multicolumn{2}{|l|}{} & \multicolumn{1}{|c|}{ Definition } \\
\hline Dependent Variables & MISCONDUCT & $\begin{array}{l}\text { An indicator variable equal to one for (1) violation years from the Federal Securities Regulation } \\
\text { Database where fraud or other intentional misconduct is alleged, (2) class period years for settled } \\
\text { securities class-action lawsuits per Stanford Securities Class Action Clearinghouse, and (3) violation } \\
\text { years for SEC and Department of Justice Enforcement Actions claiming violation of the bribery } \\
\text { provisions of the Foreign Corrupt Practices Act. }\end{array}$ \\
\hline \multirow{2}{|l|}{ ACCOUNTING_MIS } & $\begin{array}{l}\text { An indicator variable equal to one for (1) violation years from the Federal Securities Regulation } \\
\text { Database where fraud or other intentional misconduct is alleged unless the violation stems from a } \\
\text { violation of the bribery provision of the Foreign Corrupt Practices Act and (2) class period years for } \\
\text { settled securities class-action lawsuits that allege violations of Generally Accepted Accounting } \\
\text { Principles per Stanford Securities Class Action Clearinghouse. }\end{array}$ \\
\hline NONACCOUNTING_MIS & $\begin{array}{l}\text { An indicator variable equal to one for (1) class period years for settled securities class-action lawsuits } \\
\text { that do not allege violations of Generally Accepted Accounting Principles per Stanford Securities } \\
\text { Class Action Clearinghouse and (2) violation years for SEC and Department of Justice Enforcement } \\
\text { Actions claiming violation of the bribery provisions of the Foreign Corrupt Practices Act. }\end{array}$ \\
\hline
\end{tabular}




\section{Appendix A (continued) - Variable Definitions}

\begin{tabular}{|c|c|}
\hline \multicolumn{2}{|c|}{$\begin{array}{l}\text { Internal Audit Variables - all data come from the Global Auditing Information Network and Compustat databases. Compustat } \\
\text { variables names are in parenthesis. }\end{array}$} \\
\hline QUALITY & $\begin{array}{l}\text { A composite measure of internal audit function quality. The variable can range from zero to six with } \\
\text { zero representing lowest quality and six representing highest quality. The score is formed by summing } \\
\text { EXPERIENCE_IND, CERTIFICATION_IND, TRAINING_IND, NOT_TRAINING_GROUND, } \\
\text { INDEPENDENT, and IAF_SIZE_IND. }\end{array}$ \\
\hline COMPETENCE & $\begin{array}{l}\text { A factor score derived from a principal-component factor analysis of standardized measures of } \\
\text { EXPERIENCE, CERTIFICATION, TRAINING, NOT_TRAINING_GROUND, INDEPENDENT, } \\
\text { and IAF_SIZE. See Appendix C for related factor loadings. }\end{array}$ \\
\hline OBJECTIVITY & $\begin{array}{l}\text { A factor score derived from a principal-component factor analysis of standardized measures of } \\
\text { EXPERIENCE, CERTIFICATION, TRAINING, NOT_TRAINING_GROUND, INDEPENDENT, } \\
\text { and IAF_SIZE. See Appendix C for related factor loadings. }\end{array}$ \\
\hline EXPERIENCE & The average number of years of internal audit experience for year $t$ \\
\hline EXPERIENCE_IND & An indicator equal to one if EXPERIENCE is above the median, and zero otherwise. \\
\hline CERTIFICATION & The percentage of internal auditors who have CIA, CPA, or CFE certifications in year $t$. \\
\hline CERTIFICATION_IND & An indicator equal to one if CERTIFICATION is above the median, and zero otherwise. \\
\hline TRAINING & The average number of training hours internal auditors attend in year $t$. \\
\hline TRAINING_IND & An indicator equal to one if TRAINING is above the median, and zero otherwise. \\
\hline INDEPENDENT & $\begin{array}{l}\text { An indicator that is equal to one if the chief audit executive functionally reports to the audit committee } \\
\text { in year } t \text {, and zero otherwise. }\end{array}$ \\
\hline NOT_TRAINING_GROUND & $\begin{array}{l}\text { An indicator equal to one if the internal audit function is not used as a management training ground } \\
\text { during the year, and zero otherwise. }\end{array}$ \\
\hline$I A F \_S I Z E$ & $\begin{array}{l}\text { The average dollar amount spent on internal auditing for the industry in year } t \text { divided by the average } \\
\text { total sales (sale) of the industry in year } t \text {, subtracted from the dollar amount spent on internal auditing } \\
\text { per company in year } t \text { divided by the company's total sales (sale) in year } t \text {. This amount is then } \\
\text { divided by the average dollar amount spent on internal auditing for the industry in year } t \text {, divided by the } \\
\text { average total sales (sale) of the industry in year } t \text {. }\end{array}$ \\
\hline$I A F \_S I Z E_{-} I N D$ & An indicator equal to one if $I A F \_S I Z E$ is positive, and zero otherwise. \\
\hline ASSISTS_AUDITOR & The percentage of time the internal audit function spends assisting the external auditors in year $t$. \\
\hline \multicolumn{2}{|c|}{ Variables for Difference-in-Differences Design } \\
\hline MISCONDUCT_FIRM & $\begin{array}{l}\text { An indicator variable coded one if the observation is from a firm that had misconduct during the } \\
\text { sample period, and zero otherwise. For example, if firm } i \text { had misconduct for years } 2003 \text { and } 2004 \text { and } \\
\text { was in the sample from } 2000 \text { through 2009, then MISCONDUCT_FIRM would equal one for all ten } \\
\text { firm-years. }\end{array}$ \\
\hline POST_MISCONDUCT & $\begin{array}{l}\text { An indicator variable that is set to one for firm-years from misconduct firms that are subsequent to the } \\
\text { violation years (i.e., where MISCONDUCT }=0 \text { for year } t \text {, but MISCONDUCT }=1 \text { for year } t-x \text { ) and } \\
\text { for matched firm-years from the control sample. }\end{array}$ \\
\hline
\end{tabular}




\section{Appendix A (continued) - Variable Definitions}

\begin{tabular}{|c|c|}
\hline & \begin{tabular}{|c|} 
Definition \\
\end{tabular} \\
\hline \multicolumn{2}{|c|}{$\begin{array}{l}\text { Control Variables - data come from BoardEx, Compustat, Corporate Library, CRSP, and Thompson Reuters. Compustat } \\
\text { variables names are in parenthesis. }\end{array}$} \\
\hline $\mid A C \_A C C O U N T I N G \_E X P$ & $\begin{array}{l}\text { The percentage of audit committee members with accounting expertise in year } t \text {. Data for this } \\
\text { variable come from BoardEx. Accounting expertise is defined as work experience as a public auditor } \\
\text { at one of the } 25 \text { audit firms listed in Compustat, as a CPA or Chartered Accountant, or in an } \\
\text { accounting-specific position, such as CFO, Treasurer, Controller, Head of Accounting, etc. }\end{array}$ \\
\hline BRD_PCT_IND & $\begin{array}{l}\text { The percentage of directors that are independent in year } t \text {. Data for this variable come from } \\
\text { BoardEx. }\end{array}$ \\
\hline CEOISCHAIR & $\begin{array}{l}\text { An indicator variable that is equal to one if the CEO is also the chair of the board of directors in year } \\
t \text {, and zero otherwise. Data for this variable come from BoardEx. }\end{array}$ \\
\hline CEOFOUNDER & $\begin{array}{l}\text { An indicator variable that is equal to one if the CEO in year } t \text { is also the founder of the firm, and zero } \\
\text { otherwise. Data for this variable come from BoardEx and Corporate Library. }\end{array}$ \\
\hline INSTITUTIONAL_OWN & $\begin{array}{l}\text { The percentage of shares outstanding held by institutional investors at the end of year } t . \text { Data for this } \\
\text { variable come from Thompson Reuters and Compustat (csho). }\end{array}$ \\
\hline AUDITOR_SPECIALIST & $\begin{array}{l}\text { An indicator variable that is equal to one if the external auditor has the highest industry market share } \\
\text { for year } t \text {, and zero otherwise. Industry market share is calculated as the amount of annual sales } \\
\text { revenue (sale) audited in year } t \text { for a specific industry. }\end{array}$ \\
\hline LMARKETCAP & The natural log of market capitalization (prcc_f* ${ }^{*}$ csho)at the end of year $t$. \\
\hline$B M$ & $\begin{array}{l}\text { The book value of common equity (ceq) divided by the market value of common equity (prcc_f*csho) } \\
\text { at the end of year } t \text {. }\end{array}$ \\
\hline LEVERAGE & The total debt (dltt + dlc) divided by total assets (at) at the end of year $t$ \\
\hline PCTFORSALES & $\begin{array}{l}\text { Percentage of foreign sales as reported in the Compustat Segments database as a percentage of total } \\
\text { sales (sale) reported in year } t \text {. }\end{array}$ \\
\hline ISSUE & $\begin{array}{l}\text { An indicator variable coded one if the sum of issued securities (sstk }>0 \text { or ditis }>0 \text { ) during year } t \text { is } \\
\text { greater than ten percent of total assets (at) at the end of year } t \text {, and zero otherwise. }\end{array}$ \\
\hline$R S S T \_A C C$ & $\begin{array}{l}(\Delta \mathrm{WC}+\Delta \mathrm{NCO}+\Delta \mathrm{FIN}) / \text { Average total assets for year } t, \text { where } \mathrm{WC}=[\text { Current Assets (act) }- \text { Cash } \\
\text { and Short-term Investments (che)] - [Current Liabilities (lct) }- \text { Debt in Current Liabilities (dlc)]; NCO } \\
=[\text { Total Assets (at) - Current Assets (act) }- \text { Investments and Advances (ivao)] }-[\text { Total Liabilities } \\
(\text { (t) }- \text { Current Liabilities (dct) }- \text { Long-term Debt (ditt)]; FIN=[Short-term Investments (ivst) + Long- } \\
\text { term Investments (ivao)] - [Long-term Debt (dltt) + Debt in Current Liabilities (dlc) + Preferred } \\
\text { Stock (pstk)]; following Richardson et al. (2005). }\end{array}$ \\
\hline CH_REC & $\Delta$ Accounts Receivable (rect)/Average Total Assets for year $t$. \\
\hline CH_INV & $\Delta$ Inventory (invt) / Average Total Assets for year $t$. \\
\hline SOFT_ASSETS & $\begin{array}{l}\text { (Total Assets (at) - PP\&E (ppent) - Cash and Cash Equivalent (che)) / Total Assets (at) at the end } \\
\text { of year } t \text {. }\end{array}$ \\
\hline $\mathrm{CH}_{-} \mathrm{CS}$ & Percentage change in cash sales [Sales (sale) - $\Delta$ Accounts Receivable (rect)] for year $t$. \\
\hline CH_ROA & {$\left[\right.$ Earnings $_{\mathrm{t}}(\mathrm{ib}) /$ Average total assets $\left.\mathrm{t}\right]-\left[\right.$ Earnings $_{\mathrm{t}-1} /{\left.\text { Average total } \text { assets }_{\mathrm{t}-1}\right]}$} \\
\hline CH_EMP & Percentage change in the number of employees (emp) / percentage change in assets (at) for year $t$. \\
\hline$L E A S E$ & $\begin{array}{l}\text { An indicator variable coded } 1 \text { if future operating lease obligations }(\mathrm{mrc} 1, \operatorname{mrc} 2, \operatorname{mrc} 3, \operatorname{mrc} 4 \text {, and } \operatorname{mrc} 5) \\
\text { are greater than zero for year } t \text {, and zero otherwise. }\end{array}$ \\
\hline RETURN & $\begin{array}{l}\text { Annual buy-and-hold return inclusive of delisting returns minus the annual buy-and-hold value- } \\
\text { weighted market return for year } t \text {. }\end{array}$ \\
\hline FSCORE & 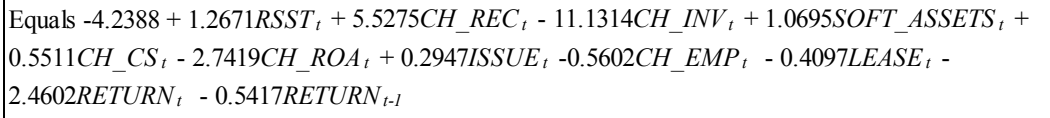 \\
\hline
\end{tabular}




\section{Appendix B - Selected Portions of the Global Auditing Information Network Survey}

This appendix presents survey questions from the Global Auditing Information Network survey that were used to calculate variables for this study. The surveys may be obtained from The Institute of Internal Auditors.

I use this question from the 2001 through 2006 surveys to calculate EXPERIENCE.

- B6. Indicate the average years of experience in the following categories:

o Average years in Internal Auditing

o Average years in Public Auditing

o Average years other than Internal Auditing

In the 2007 through 2010 surveys the question is presented by employee level (i.e., Chief Audit Executives, Directors, Seniors, and Staff). Accordingly, in order to calculate EXPERIENCE for the corresponding firm-years, I take the average internal audit experience by level and multiply these averages by the number of full time employees and sourced staff at each level. I then calculate the overall average years of internal audit experience.

I use this survey question to calculate CERTIFICATION.

- B6 (for 2007 survey) or B9 (for 2008 through 2010 surveys). Total \# of Professional Staff with the following Certifications:

o Certified Internal Auditor (CIA) or member of the Institute of Internal Auditors - United Kingdom (MIIA)

o Certified Public Accountant (CPA) or Chartered Accountant (CA) 
o Certified Information Systems Auditor (CISA) or Qualification in Computer Auditing (QiCA)

o Certified Bank Auditor (CBA) or Certified Financial Services Auditor (CFSA)

o Certified Management Accountant (CMA)

o Certified Fraud Examiner (CFE)

o Other

The question wording varies slightly across the sample period, but in each year the question did ask specifically for the number of professional staff with a CIA, CPA, and CFE. To calculate CERTIFICATION I add the numbers entered above for the CIA, CPA, and CFE and then divide this summation by the total number of professional staff.

I use this survey question to calculate TRAINING.

- B15 (for 2001 through 2006 surveys), H9 (for 2007 and 2008 surveys), or H6 (for 2009 survey), or H3 (for 2010 survey). Including both internal and external courses, how many hours of training per auditor were:

o Budgeted (hours per auditor)

o Actually Performed (hours per auditor)

TRAINING is the number actually performed. In the 2007 through 2010 surveys, the question specifically notes that the answers should exclude hours for travel.

I use this question from the 2001 through 2006 surveys to calculate NOT_TRAINING_GROUND. 
- B16. Are staff auditors encouraged to make auditing their career (vs. rotational auditors that are "developed in audit" but placed elsewhere in the organization):

o Rotational / prepare for other areas of the company

o Mostly rotational but some auditors career or changing to career oriented

o Career

o Career but moving towards rotational

The 2005 survey lists the following as response options to the question:

- Rotational

- Rotational but moving towards permanent career

- Career but moving towards rotational

- Career

I set NOT_TRAINING_GROUND to zero for firm-years with a response of "Rotational / prepare for other areas of the company" or "Rotational", and to one otherwise. A question regarding the use of the IAF as a management training ground was not asked in the 2007 through 2010 surveys. For these years, I predict whether the firm is using the IAF in this manner by first calculating the percentage of professional staff turnover that was placed inside the company by using the following question:

- B7 (for 2001 through 2006 surveys), B9 (for 2007 survey), or B13 (for 2008 through 2010 surveys). What was your internal audit staff turnover for the year:

o Placed inside the organization

o Voluntarily left organization

o Retirements 
o Other

I then determine the average placed inside the organization for years 2000 through 2005 (i.e., years associated with 2001 through 2006 survey questions) where NOT_TRAINING_GROUND is set to zero. Then, for years 2006 through 2009, I set NOT_TRAINING_GROUND to zero for firm-years where the percentage of staff turnover that was placed inside the company was above the average for years 2000 through 2005 where NOT_TRAINING_GROUND is set to zero.

I use this survey question to calculate INDEPENDENT.

- For 2001 through 2002 surveys

o E6b. CAE Reporting Relationship: Functionally - Who is responsible for policy and general direction?

- Audit Committee

- Chief Executive Officer

- President

- Chief Financial Officer

- Controller

- Other

- E6b. For 2003 through 2006 surveys

o CAE Reporting Relationship: Functionally - Approves CAE Audit Plan

- Audit Committee

- Chief Executive Officer

- President 
- Chief Financial Officer

- Controller

- Other

- C2 (for 2007 survey) or C3 (for 2008 survey). For 2007 through 2008 surveys

o The CAE reports functionally to:

- Audit Committee, or equivalent

- General / Legal Counsel

- Chief Executive Officer (CEO)

- President or Government Agency Head

- Chief Financial Officer (CFO)

- Chief Operating Officer (COO)

- Controller

- Other

- C3. For 2009 through 2010 surveys

o The CAE reports functionally to:

- Audit Committee, or equivalent

- General / Legal Counsel

- Chief Executive Officer (CEO)

- President or Government Agency Head

- Chief Financial Officer (CFO)

- Chief Operating Officer (COO)

- Chief Risk Officer (CRO) 
- Controller

- Other

When "Audit Committee" or "Audit Committee, or equivalent" is selected, I set INDEPENDENT equal to one, and zero otherwise.

In order to calculate $I A F \_$SIZE I utilize a question that asks for the total departmental costs. This question lists different options each year, but a total cost can be calculated for each year. Following is an example from the 2001 survey:

- B1. These costs apply to everyone in B4 below
o Total Salary Costs

o Total Travel Costs

o Total Training Costs

o Total Costs of Purchasing Internal Audit services through $3^{\text {rd }}$ Parties other than Salary Earners

o Major Non-recurring Expenses

o Total of all Other Costs

o Total Department Costs

I use this survey question to calculate ASSISTS_AUDITOR.

- F5 (for 2001 through 2006 surveys), E1 (for 2007 through 2010 surveys). What \% of your audit staff time was actually devoted to:

o Auditing (Non-Information Technology)

o IT Auditing

o Fraud Investigation 
o Special Projects (Management requests; Key is that management requests either during annual planning or during the year)

o External Audit Assistance

o Auditor Administration

o Supporting Company-wide Reengineering Process

o Supporting Company-wide Quality Efforts

o Supporting Company-wide Control Self-assessment Programs

o Providing Internal Control Programs for the Corporation

o Training

o Absences (Holidays, Vacation, Sick-time, Etc.)

o Travel

o Other

The response options for this question varies significantly across the sample period, but in each year the question did provide an option that specifically asks about external audit assistance. I include two additional examples of this question to provide the reader insight into the different options provided throughout the sample period. The verbiage above is from the 2001 survey. The 2006 survey options for this question were:

- Financial - Auditing annual accounts, financial statements and reports

- Operational / general Auditing

- IT Auditing

- Fraud Investigations

- Special - Management requests during annual planning or during the year 
- External Audit Assistance

- Auditor Administration / other

- Supporting Company-wide Reengineering Process

- Supporting Company-wide Quality Efforts

- Supporting Company-wide Control Self-assessment Programs

- Providing Internal Control Programs for the Corporation

- Training

- Absences (Holidays, Vacation, Sick-time, Etc.)

- Travel

- $\mathrm{SOX}$

- Other

The 2009 survey options for this question were:

- Assurance engagements

- Consulting engagements

- Management requests

- Fraud investigations

- Follow-up audits

The questions I use to calculate the percentage of IAF outsourcing change with the 2007 survey. I use the following survey questions to calculate OUTSOURCED (see Table 12) for firm-years 2000 through 2005 (i.e., 2001 through 2006 surveys).

- A8. Extent of General Internal Audit $3^{\text {rd }}$ party work?

o $100 \%$ 

$0 \quad>50 \%$
o $>25 \%$
o Some
o None

- A9. Extent of IT Internal Audit $3^{\text {rd }}$ party work?
o $100 \%$
o $>50 \%$
o $>25 \%$
o Some
o None

I then create a variable for each question that equals zero, one, two, three, or four if the response is none, some, $>25 \%,>50 \%$, or $100 \%$, respectively. Finally, I average the composite variables for these two questions. For example, if for A8 the answer is $>25 \%$ and for A9 the answer is $>50 \%$, then OUTSOURCED $=2.5$.

For firm-years 2006 through 2009 (i.e., 2007 through 2010 surveys), I use the following survey question to calculate OUTSOURCED:

- B14. What percentage of your audit engagements are (must add to $100 \%$ )
o Staffed internally
o Co-sourced
o Outsourced

I then create a variable that equals zero, one, two, three, or four if the sum of the percentages for co-sourced and outsourced is none, greater than zero and less than or 
equal to 25 percent, greater than 25 percent and less than or equal to 50 percent, greater than 50 percent and less than 100 percent, or 100 percent, respectively. For example, if for B14 the answer is 25 percent for co-sourced and 5 percent for outsourced, then OUTSOURCED $=2$.

To calculate FINANCIAL_FOCUS (see Table 13) I use the following questions from the 2001 through 2006 surveys.

- How frequently were the following types of audits performed (Regularly, Occasionally, or Never)?

o G1a. Adequacy of Internal Accounting Controls

o G1b. Accuracy, Reliability, and Completeness of Financial Records

o G1d. Impact of changes in Accounting Rules or Regulations

o G1e. Interim quarterly Financial Results reported Externally

o G3e. Generally Accepted Accounting Principles

I assign a zero to each response of never, a one to each response of occasionally, and a two to each response of regularly. FINANCIAL_FOCUS is the average of these five responses. 


\section{Appendix C - IAF Quality Factor Loadings}

\begin{tabular}{|lcc|}
\hline \multicolumn{1}{|c|}{ Variables } & Factor 1 - Competence & Factor 2 - Objectivity \\
\hline EXPERIENCE & & \\
CERTIFICATION & 0.554 & -0.038 \\
TRAINING & 0.456 & -0.172 \\
NOT_TRAINING_GROUND & 0.061 & -0.494 \\
INDEPENDENT & 0.390 & 0.182 \\
IAF_SIZE & -0.078 & 0.556 \\
& 0.100 & 0.502 \\
\hline \hline
\end{tabular}

This table presents standardized scoring coefficients for the two factors with eigenvalues greater than one that result from a principal components factor analysis of EXPERIENCE, CERTIFICATION, TRAINING, NOT_TRAINING_GROUND, $I N D E P E N D E N T$, and IAF_SIZE. Variable definitions are provided in Appendix A. 


\section{Appendix D - F-score Coefficient Regression}

\begin{tabular}{|c|c|c|}
\hline \multicolumn{3}{|c|}{ Prob $\left(A C C O U N T I N G_{-} M I S=1\right)=\mathrm{F}\left(\beta_{0}+\right.$ Controls $)$} \\
\hline Independent Variables & Predicted Sign & ACCOUNTING \\
\hline Intercept & $?$ & $\begin{array}{l}-4.2388 * * * \\
(0.623)\end{array}$ \\
\hline$R S S T \_A C C$ & + & $\begin{array}{l}1.2671 \\
(2.118)\end{array}$ \\
\hline CH_REC & + & $\begin{array}{l}5.5275 \\
(4.898)\end{array}$ \\
\hline CH_INV & + & $\begin{array}{c}-11.1314 \\
(6.715)\end{array}$ \\
\hline SOFT_ASSETS & + & $\begin{array}{r}1.0695 \\
(0.908)\end{array}$ \\
\hline $\mathrm{CH}_{-} \mathrm{CS}$ & + & $\begin{array}{l}0.55111^{* *} \\
(0.285)\end{array}$ \\
\hline CH_ROA & - & $\begin{array}{r}-2.7419 \\
(2.260)\end{array}$ \\
\hline ISSUE & + & $\begin{array}{l}0.2947 \\
(0.510)\end{array}$ \\
\hline $\mathrm{CH}_{-} E M P$ & - & $\begin{array}{r}-0.5602 \\
(0.644)\end{array}$ \\
\hline LEASE & + & $\begin{array}{l}-0.4097 \\
(0.609)\end{array}$ \\
\hline$R_{E T U R N_{t}}$ & + & $\begin{array}{l}-2.4602 \text { *** } \\
(0.380)\end{array}$ \\
\hline$R E T U R N_{t-1}$ & + & $\begin{array}{l}-0.5417 \\
(0.591)\end{array}$ \\
\hline Obs. where $A C C O U N T I N G=1$ & & 37 \\
\hline Total Obs. & & 1,044 \\
\hline
\end{tabular}


This table reports the results of a logistic regression based upon Model 3 from Dechow et al. (2011). The model is as follows:

$$
\begin{aligned}
& \text { Prob (ACCOUNTING_MIS }=1) \mathrm{F}\left(\beta_{0}+\beta_{1} \mathrm{RSST}_{\mathrm{t}}+\beta_{2} \mathrm{CH}_{-} \mathrm{REC}_{\mathrm{t}}+\beta_{3} \mathrm{CH}_{-} \mathrm{INV}_{\mathrm{t}}+\right. \\
& \beta_{4} \text { SOFT_ASSETS }_{\mathrm{t}}+\beta_{5} \mathrm{CH}_{-} \mathrm{CS}_{\mathrm{t}}+\beta_{6} \mathrm{CH}_{-} \mathrm{ROA}_{\mathrm{t}}+\beta_{7} \mathrm{ISSUE}_{\mathrm{t}}+\beta_{8} \mathrm{CH}_{-} \mathrm{EMP}_{\mathrm{t}}+\beta_{9} \text { LEASE }_{\mathrm{t}}+ \\
& \left.\beta_{10} \text { RETURN }_{\mathrm{t}}+\beta_{11} \text { RETURN }_{\mathrm{t}-1}\right)
\end{aligned}
$$

The accounting-related misconduct sample includes (1) violation years from the Federal Securities Regulation Database where fraud or other intentional misconduct is alleged unless the violation stems from a violation of the bribery provision of the Foreign Corrupt Practices Act of 1977 and (2) class period years for settled securities class-action lawsuits that allege violations of Generally Accepted Accounting Principles per Stanford Securities Class Action Clearinghouse. The coefficients from this regression are used in equation (3) in the text.

Variable defintions are provided in Appendix A. Standard errors clustered by firm are in parentheses. *, **, and $* * *$ denote statistical significance at the $10 \%, 5 \%$, and $1 \%$ levels, respectively, using a one-tailed test where the coefficient sign is consistent with the predicted direction. 


\section{References}

American Institute of Certified Public Accountants (AICPA). 2008. Managing the business risk of fraud: a practical guide. Also sponsored by The Institute of Internal Auditors and Association of Certified Fraud Examiners. Available at http://www.aicpa.org/InterestAreas/ForensicAndValuation/Resources/FraudPreve ntionDetectionResponse/DownloadableDocuments/managing business risk frau d.pdf (accessed May 2, 2012).

American Institute of Certified Public Accountants (AICPA). 2007. Consideration of fraud in a financial statement audit. Statement on Auditing Standards No. 99. Available at: http://www.aicpa.org/Research/Standards/AuditAttest/DownloadableDocuments/ AU-00316.pdf (accessed November 29, 2012).

American Institute of Certified Public Accountants (AICPA). 2005. Management override of internal controls: the Achilles' heel of fraud prevention. Available at http://www.aicpa.org/ForThePublic/AuditCommitteeEffectiveness/Downloadable Documents/achilles heel.pdf (accessed November 14, 2012).

American Institute of Certified Public Accountants (AICPA). 1997. The auditor's consideration of the internal audit function in an audit of financial statements. Statement on Auditing Standards No. 65. Available at: http://www.aicpa.org/Research/Standards/AuditAttest/DownloadableDocuments/ AU-00322.pdf (accessed May 2, 2012).

Archambeault, D.S., F.T. DeZoort, and T.P. Holt. 2008. The need for an internal auditor report to external stakeholders to improve governance transparency. Accounting Horizons 22 (4): 375-388.

Ashbaugh-Skaife, H., D.W. Collins, W.R. Kinney, Jr., and R. LaFond. 2008. The effect of SOX internal control deficiencies and their remediation on accrual quality. The Accounting Review 83: 217-250.

Badolato, P., D.C. Donelson, M. Ege. 2012. Audit committee financial expertise and accounting irregularities: the role of status. Working Paper.

Bartus, T. 2005. Estimation of marginal effects using margeff. Stata Journal 5 (3): 309329.

Beasley, M.S. 1996. An empirical analysis of the relation between the board of director composition and financial statement fraud. The Accounting Review 71: 443-465. 
Beasley, M.S., J.V. Carcello, D.R. Hermanson, and P.D. Lapides. 2000. Fraudulent financial reporting: consideration of industry traits and corporate governance mechanisms. Accounting Horizons 14 (4): 441-454.

Beasley, M.S., J.V. Carcello, D.R. Hermanson, and T.L. Neal. 2009. The audit committee oversight process. Contemporary Accounting Research 26 (1): 65-122.

Beneish, M.D. 1999. Incentives and penalties related to earnings overstatements that violate GAAP. The Accounting Review 74 (4): 425-457.

Birk, M. 2010. Prescription for FCPA compliance. Internal Auditor 67 (1): 53-57.

Board of Governors of the Federal Reserve System. 2013. Supplemental policy statement on the internal audit function and its outsourcing. Available at: http://www.federalreserve.gov/bankinforeg/srletters/sr1301a1.pdf (accessed March 8, 2013).

Burton, F.G., M. Starliper, S.L. Summers, and D.A. Wood. 2012. Recruiting internal auditors: the effects of using the internal audit function as a management training ground and performing consulting services. Working Paper.

Chadwick, W.E. 2000. Keeping internal auditing in-house. Internal Auditor 57 (3): 88.

Christ, M.H., A. Masli, N.Y. Sharp, and D.A. Wood. 2012. Using the internal audit function as a management training ground: is the monitoring effectiveness of internal auditors compromised? Working Paper.

Committee of Sponsoring Organizations of the Treadway Commission (COSO). 2012. Internal control - integrated framework. Exposure Draft, September 2012. Available at http://www.ic.coso.org (accessed November 11, 2012).

Dechow, P.M., W. Ge, C.R. Larson, and R.G. Sloan. 2011. Predicting material accounting misstatements. Contemporary Accounting Research 28 (1): 17-82.

Dechow, P.M., R.G. Sloan, and A.P. Sweeney. 1996. Causes and consequences of earnings manipulation: an analysis of firms subject to enforcement actions by the SEC. Contemporary Accounting Research 13: 1-36.

DeFond, M., R. Hann, and X. Hu. 2005. Does the market value financial expertise on audit committees of boards of directors? Journal of Accounting Research 43 (2): 153-193. 
Dhaliwal, D.C., V. Naiker, and F. Navissi. 2010. The association between accruals quality and the characteristics of accounting experts and mix of expertise on audit committees. Contemporary Accounting Research 27: 787-827.

Donelson, D.C., J. McInnis, and R.D. Mergenthaler. 2012. The effect of corporate governance reform on financial reporting fraud. Working Paper.

Ernst \& Young. 2007. Global internal audit survey: a current state analysis with insights into future trends and leading practices. Available at:

http://www.juhtimine.ee/static/artiklid/188.Global\%20Internal\%20Audit\%20Surv ey.pdf (accessed on December 3, 2012).

Fama, E.F. and M.C. Jensen. 1983. Separation of ownership and control Journal of Law and Economics 26: 301-325.

Farber, D.B. 2005. Restoring trust after fraud: does corporate governance matter? The Accounting Review 80 (2): 539-561.

Financial Executives Research Foundation (FERF). 2013. The last mile of finance: how organizations are performing record to report. Available at: http://www.financialexecutives.org/KenticoCMS/News---Publications/ResearchPublications.aspx (accessed on March 8, 2013).

Francis, J.R., K. Reichelt, and D. Wang. 2005. The pricing of national and city-specific reputations for industry expertise in the U.S. audit market. The Accounting Review 80 (1): 113-136.

Gramling, A.A., M.J. Maletta, A. Schneider, and G.K. Church. 2004. The role of the internal audit function in corporate governance: a synthesis of the extant internal auditing literature and directions for future research. Journal of Accounting Literature 23: 194-244.

Holt, T.P., and T. DeZoort. 2009. The effects of internal audit report disclosure on investor confidence and investment decisions. International Journal of Auditing 13: 61-77.

Institute of Internal Auditors (IIA). 2012. International standards for the professional practice of internal auditing. Altamonte Springs, FL: IIA. Available at http://www.theiia.org/guidance/standards-and-guidance/ippf/standards/ (accessed October 3, 2012).

International Auditing and Assurance Standards Board (IAASB). 2012. Using the work of internal auditors. International Standards on Auditing 610 (Revised). Available at 
http://www.ifac.org/sites/default/files/publications/files/ISA\%20610\%20(Revised $\% 20$ and $\% 20$ Conforming\%20Amendments\%20-\%20final.pdf (accessed May 2, 2012).

Karpoff, J.M., D.S. Lee, and G.S. Martin. 2008a. The consequences to managers for financial misrepresentation. Journal of Financial Economics 88 (2): 193-215.

Karpoff, J.M., D.S. Lee, and G.S. Martin. 2008b. The cost to firms of cooking the books. Journal of Financial and Quantitative Analysis 43 (3): 581-612.

Klein, A. 2002. Audit committee, board of director characteristics, and earnings management. Journal of Accounting and Economics 33: 375-400.

Krishnan, J. 2005. Audit committee quality and internal control: An empirical analysis The Accounting Review 80 (2): 649-675.

Krishnan, G.V. and G. Visvanathan. 2008. Does the SOX definition of an accounting expert matter? The association between audit committee directors' accounting expertise and accounting conservatism. Contemporary Accounting Research 25: $827-858$.

Larcker, D.F., S.A. Richardson, and I. Tuna. 2007. Corporate governance, accounting outcomes and organizational performance. The Accounting Review 82 (4): 9631008 .

Larcker, D.F., and T.O. Rusticus. 2010. On the use of instrumental variables in accounting research. Journal of Accounting and Economics 49: 186-205.

Lennox, C., and J.A. Pittman. 2010. Big five audits and accounting fraud. Contemporary Accounting Research 27 (1): 209-247.

Lev, B., and T. Sougiannis. 1996. The capitalization, amortization, and value-relevance of R\&D. Journal of Accounting \& Economics 21: 107-138.

Lin, S., M. Pizzini, M. Vargus, and I.R. Bardhan. 2011. The role of the internal audit function in the disclosure of material weaknesses. The Accounting Review 86(1): 287-323.

Lucas, N. 2004. An interview with United States Senator Paul S. Sarbanes. Journal of Leadership and Organizational Studies 11: 3-8.

Messier, W.F., J.K. Reynolds, C.A. Simon, and D.A. Wood. 2011. The effect of using the internal audit function as a management training ground on the external auditor's reliance decision. The Accounting Review 86 (6): 2131-2154. 
Norman, C.S., A.M. Rose, and J.M. Rose. 2010. Internal audit reporting lines, fraud risk decomposition, and assessments of fraud risk. Accounting, Organizations and Society 35: 546-557.

Office of Inspector General (OIG). 2012 Corporate integrity agreement between the Office of Inspector General of the Department of Health and Human Services and Amgen, Inc. https://oig.hhs.gov/fraud/cia/agreements/Amgen 12142012.pdf (accessed May 10, 2013).

Office of the Comptroller of the Currency (OCC). 2003. Revised guidance on internal audit and its outsourcing. Available at http://www.occ.gov/newsissuances/bulletins/2003/bulletin-2003-12a.pdf (accessed November 9, 2012).

Palmrose, Z-V. 1986. Audit fees and auditor size: further evidence. Journal of Accounting Research 24 (Spring): 97-110.

Pizzini, M., S. Lin, and D. Ziegenfuss. 2012. The impact of internal audit function quality and contribution on audit delays. Working Paper.

Pollack, A. and M. Secret. 2012. Amgen agrees to pay $\$ 762$ million for marketing anemia drug for off-label use. The New York Times, December 18. Available at http://www.nytimes.com/2012/12/19/business/amgen-agrees-to-pay-762-millionin-drug-case.html? $\mathrm{r}=0$ (accessed May 10, 2013).

Prawitt, D.F., N.Y. Sharp, and D.A. Wood. 2012. Internal audit outsourcing and the risk of misleading or fraudulent financial reporting: did Sarbanes-Oxley get it wrong? Contemporary Accounting Research. Forthcoming.

Prawitt, D.F., J.L. Smith, and D.A. Wood. 2009. Internal audit quality and earnings management. The Accounting Review 84 (4): 1255-1280.

Price, R.A., N.Y. Sharp, and D.A. Wood. 2011. Detecting and predicting accounting irregularities: a comparison of commercial and academic risk measures. Accounting Horizons 25 (4): 755-780.

Protiviti. 2007. Guide to internal audit: frequently asked questions about developing and maintaining an effective internal audit function. Second edition. Available at http://www.intellityconsulting.com/recursos/recurso/GuideInternal_Audit-FAQs2n Edition.pdf (accessed November 30, 2012).

Public Company Accounting Oversight Board (PCAOB). 2010. AU Section 322: The auditor's consideration of the internal audit function in an audit of the financial 
statements. Available at

http://pcaobus.org/Standards/Auditing/Pages/AU322.aspx (accessed April 10, 2012).

Public Company Accounting Oversight Board (PCAOB). 2007 Auditing Standard No. 5, An Audit of Internal Control Over Financial Reporting That Is Integrated with An Audit of Financial Statements. http://pcaobus.org/Standards/Auditing/Pages/Auditing_Standard 5.aspx (accessed April 10, 2012).

Public Company Accounting Oversight Board (PCAOB). 2004. An audit of internal control over financial reporting performed in conjunction with an audit of financial statements. Auditing Standard No. 2. Washington, D.C.: PCAOB.

Reding, K.F., P.J. Sobel, U.L. Anderson, M.J. Head, S. Ramamoorti, M. Salamasick, and C. Riddle. 2009. Internal auditing: assurance \& consulting services. Second edition. Altamonte Springs, FL: The Institute of Internal Auditors Research Foundation.

Richardson, S., R. Sloan, M. Soliman, and I. Tuna. 2005. Accrual reliability, earnings persistence, and stock prices. Journal of Accounting \& Economics 39 (3): 437485.

Schneider, A., and N. Wilner. 1990. A test of audit deterrent to financial reporting irregularities using randomized response technique. The Accounting Review 65 (3): 668-681.

Securities and Exchange Commission (SEC). 2013. Notice of filing of proposed rule change to require that listed companies have an internal audit function. Release No. 34-69030. Available at http://www.sec.gov/rules/sro/nasdaq/2013/3469030.pdf (accessed March 25, 2013).

Securities and Exchange Commission (SEC). 2012a. SEC charges medical device company Biomet with foreign bribery. SEC, Washington, DC, March 26. Available at http://www.sec.gov/news/press/2012/2012-50.htm (accessed November 2, 2012).

Securities and Exchange Commission (SEC). 2012b. SEC versus Biomet, Inc. SEC, Washington, DC, March 26. Available at http://www.sec.gov/litigation/complaints/2012/comp22306.pdf (accessed November 2, 2012). 
Securities and Exchange Commission (SEC). 2012c. SEC versus Thomas F. O'Rourke. SEC, Washington, DC, February 24. Available at http://www.sec.gov/litigation/complaints/2012/comp-pr2012-32-1.pdf (accessed May 4, 2012).

Securities and Exchange Commission (SEC). 2003a. Comments on proposed rule: standards relating to listed company audit committees. Release Nos. 33-8173, 3447137. Available at http://www.sec.gov/rules/proposed/s70203.shtml (accessed November 28, 2012).

Securities and Exchange Commission (SEC). 2003b. Disclosure required by Sections 406 and 407 of the Sarbanes-Oxley Act of 2002. Release Nos. 33-8177, 34-47235. Available at http://www.sec.gov/rules/final/33-8177.htm (accessed December 5, 2012).

Securities and Exchange Commission (SEC). 2003c. Final rule: standards related to listed company audit committees. Release Nos. 33-8220, 34-47654. Available at http://www.sec.gov/rules/final/33-8220.htm (accessed October 3, 2012).

Securities and Exchange Commission (SEC). 2003d. NASD and NYSE rulemaking: relating to corporate governance. Release No. 34-48745. Available at http://www.sec.gov/rules/sro/34-48745.htm (accessed November 29, 2012).

Shleifer, A., and R. Vishny. 1986. Large shareholders and corporate control. Journal of Political Economy 94 (3): 461-488.

Tabuena, J. 2010. Internal audit's role in preventing FCPA violations. Compliance Week, March 2.

Uecker, W.C., A.P. Brieft, and W.R. Kinney, Jr. 1981. Perception of the internal and external auditor as a deterrent to corporate irregularities. The Accounting Review 56 (3): 465-478.

Yermack, D. 1996. Higher market valuation of companies with a small board of directors. Journal of Financial Economics 40 (2): 185-211. 